Prepared in cooperation with the Kansas Water Office

\title{
Groundwater-Flow Model of the Ozark Plateaus Aquifer System, Northwestern Arkansas, Southeastern Kansas, Southwestern Missouri, and Northeastern Oklahoma
}

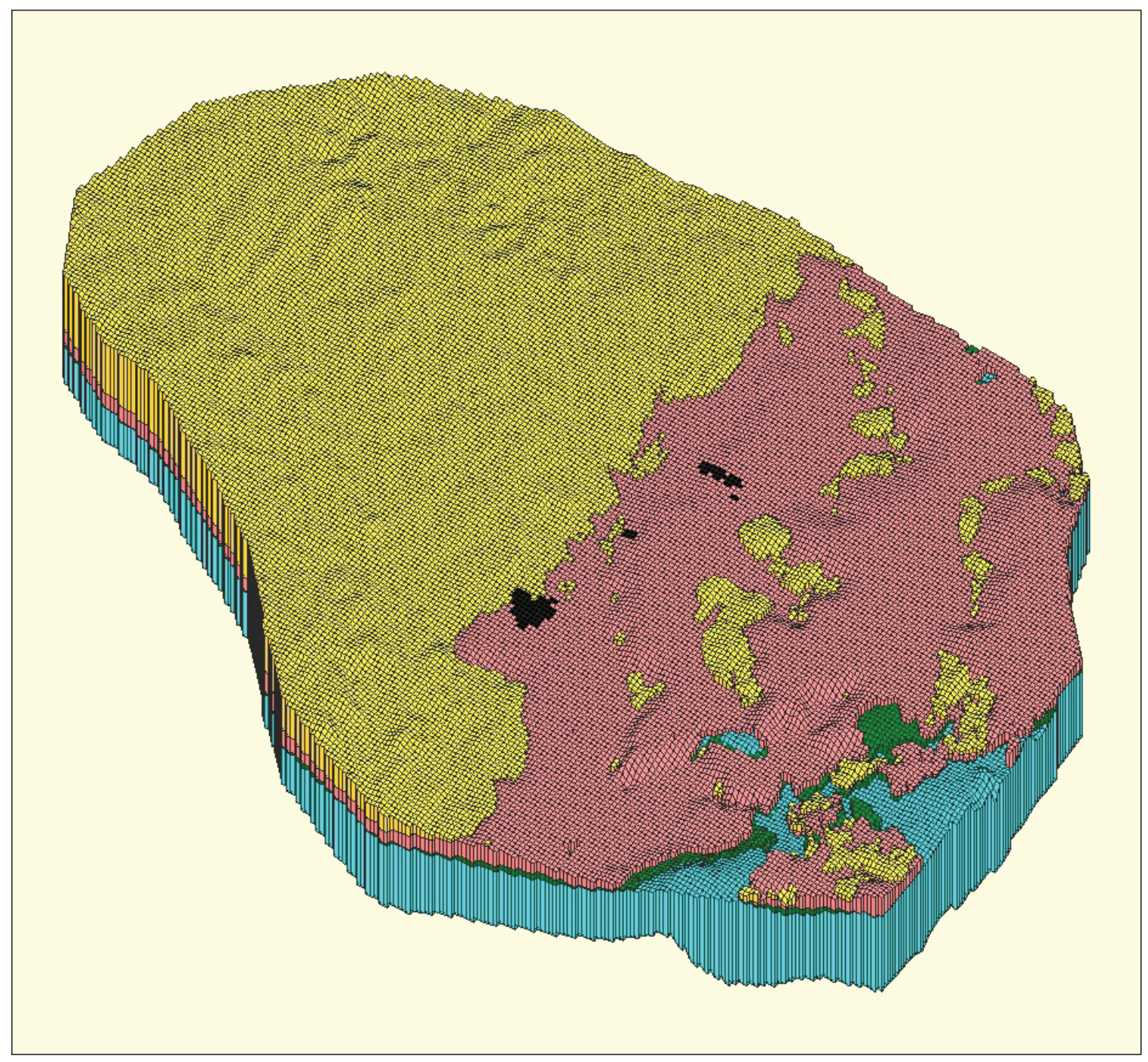

Scientific Investigations Report 2009-5148

Revised March 2010 


\section{Groundwater-Flow Model of the Ozark Plateaus Aquifer System, Northwestern Arkansas, Southeastern Kansas, Southwestern Missouri, and Northeastern Oklahoma}

By John B. Czarnecki, Jonathan A. Gillip, Perry M. Jones, and Daniel S. Yeatts

In cooperation with the Kansas Water Office

Scientific Investigations Report 2009-5148 


\section{U.S. Department of the Interior \\ KEN SALAZAR, Secretary \\ U.S. Geological Survey \\ Marcia K. McNutt, Director}

\section{U.S. Geological Survey, Reston, Virginia: 2010}

For product and ordering information:

World Wide Web: http://www.usgs.gov/pubprod

Telephone: 1-888-ASK-USGS

For more information on the USGS--the Federal source for science about the Earth, its natural and living resources, natural hazards, and the environment:

World Wide Web: http://www.usgs.gov

Telephone: 1-888-ASK-USGS

Any use of trade, product, or firm names is for descriptive purposes only and does not imply endorsement by the U.S. Government.

Although this report is in the public domain, permission must be secured from the individual copyright owners to reproduce any copyrighted materials contained within this report.

Suggested citation:

Czarnecki, J.B., Gillip, J.A., Jones, P.M., and Yeatts, D.S., 2009, Groundwater-flow model of the Ozark Plateaus aquifer system, northwestern Arkansas, southeastern Kansas, southwestern Missouri, and northeastern Oklahoma: U.S. Geological Survey Scientific Investigations Report 2009-5148 (Revised March 2010), 62 p. 


\section{Contents}

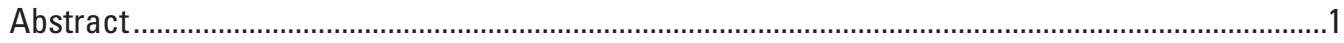

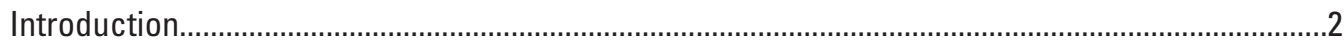

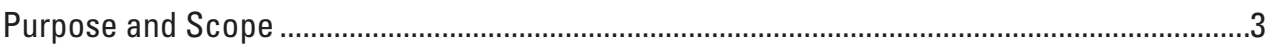

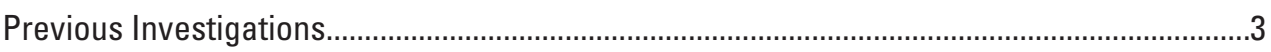

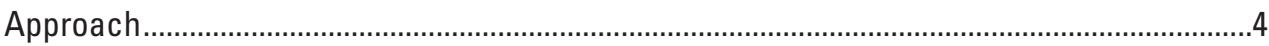

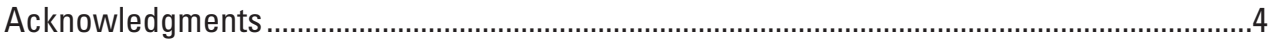

Description of Model Area .................................................................................................................

Hydrogeologic Setting of the Ozark Plateaus Aquifer System...........................................................6

Western Interior Plains Confining Unit........................................................................................ 6

Springfield Plateau Aquifer ...................................................................................................

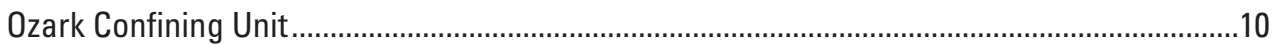

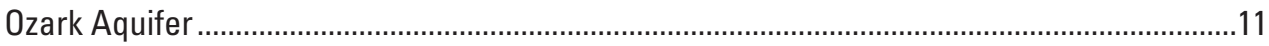

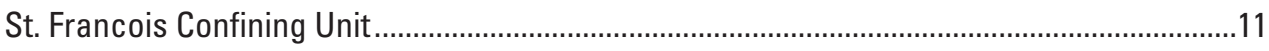

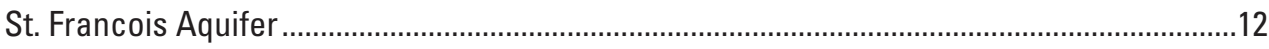

Basement Confining Unit..................................................................................................... 12

Conceptual Model of Flow System ...........................................................................................12

Description of Groundwater-Flow Model .................................................................................12

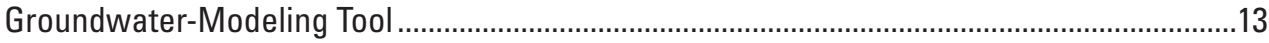

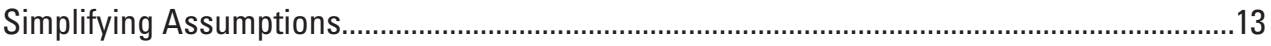

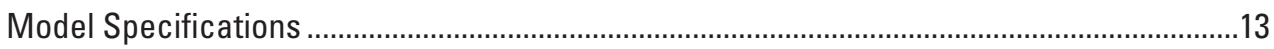

Finite-Difference Grid............................................................................................... 13

Stress Period Discretization .................................................................................................

Model Boundary Conditions ..........................................................................................

Areally Distributed Recharge ...............................................................................

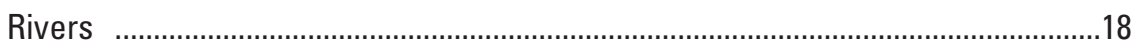

Constant-Head Boundaries............................................................................... 18

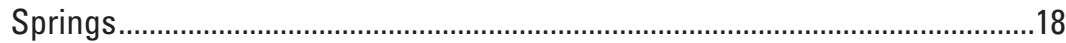

Grand Lake of the Cherokees ......................................................................... 18

General-Head Boundaries .................................................................................. 18

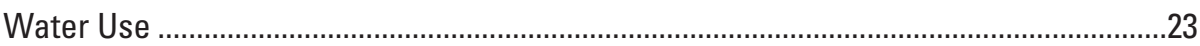

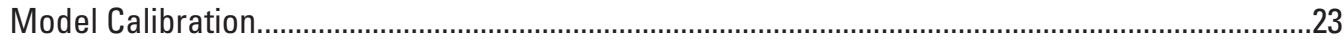

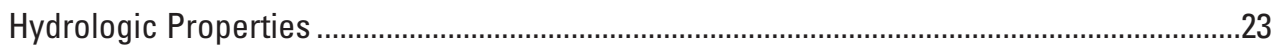

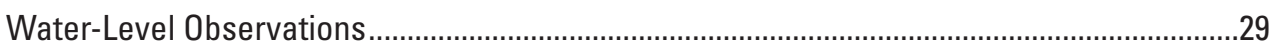

Streamflow Observations .......................................................................................................

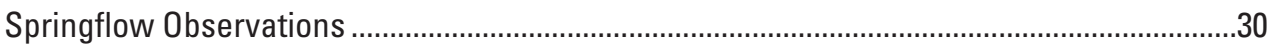

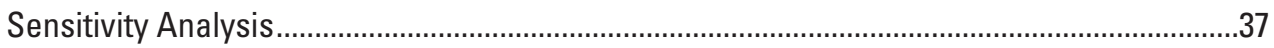

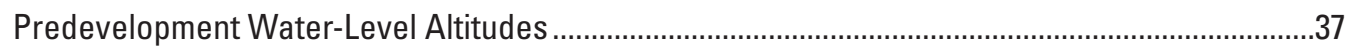

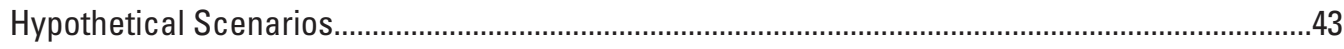

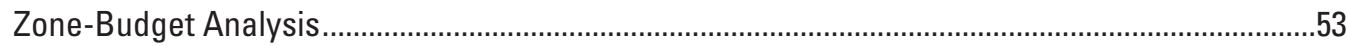

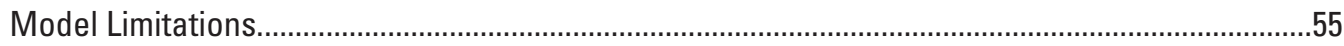

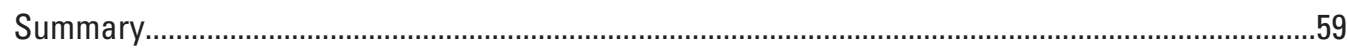

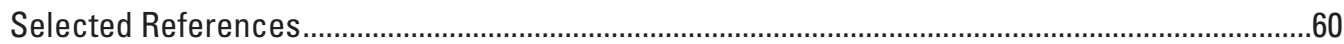




\section{Figures}

1-3. Maps showing:

1. Extent of the Ozark Plateaus aquifer system and location of model area .........................2

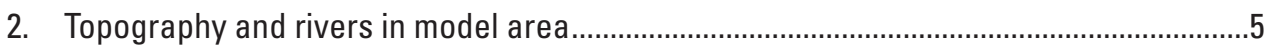

3. Location of model area, faults, and water-well moratorium area ....................................

4. Schematic cross section of the regional hydrogeologic units in and adjacent to the Ozark Plateaus aquifer system ..................................................................................

5-14. Maps showing:

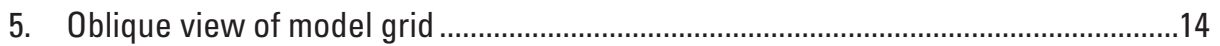

6. Plan view of model showing layer occurrences at top of the model .......................15

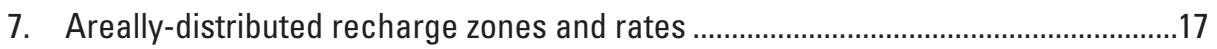

8. Distribution of rivers and lakes specified in the model..............................................19

9. Constant-head and general-head boundary conditions, layer 2 (Springfield

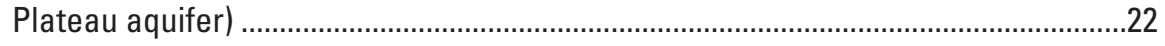

10. General-head boundary conditions, layer 4 (Ozark aquifer) ....................................24

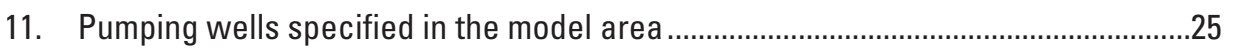

12. Water use (Springfield Plateau and Ozark aquifers combined) in 2006 ....................26

13. Hydrologic property zones for (A) Layer 1 (Western Interior Plains confining unit), (B) Layer (Springfield Plateau aquifer), (C) Layer 3 (Ozark confining unit),

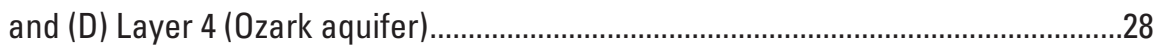

14. Simulated water-level altitudes in Ozark aquifer and differences between observed and simulated water-level altitude, 1985.

15. Graph showing relation between simulated water-level altitudes and observed water-level altitudes for measurements made between 1980 to 1989 for the Ozark aquifer

16. Histogram showing difference between observed and simulated water-level altitudes for the period 1980 to 1989 for the Ozark aquifer

17. Map showing simulated water-level altitudes in Ozark aquifer and difference between observed and simulated water-level altitude in 2006.

18. Graph showing relation between simulated water-level altitudes and observed water-level altitudes for measurements made for 2006 for the Ozark aquifer.

19. Histogram of the difference between observed and simulated water-level altitudes for 2006 for the Ozark aquifer.

20. Map showing simulated water-level altitudes in Springfield Plateau aquifer and difference between observed and simulated water-level altitude in 2006.

21. Graph showing relation between simulated water-level altitudes and observed water-level altitudes for measurements made for $\mathbf{2 0 0 6}$ for the Springfield Plateau aquifer.

22. Histogram showing difference between observed and simulated water-level altitudes for 2006 for the Springfield Plateau aquifer

23-25. Maps showing:

23. Simulated predevelopment water-level altitudes in the Springfield Plateau aquifer (layer 2).

24. Simulated predevelopment water-level altitudes in the Ozark aquifer...

25. Simulated water-level altitudes at the end of 2057 in the Ozark aquifer for hypothetical scenario 1

26. Graph showing simulated water-level altitude with time at five pumping centers in the model area for hypothetical scenario 1 
27. Map showing simulated water-level altitudes at the end of 2057 in the Ozark aquifer for hypothetical scenario 2 .....

28. Graph showing simulated water-level altitude with time at five pumping centers in the model area for hypothetical scenario 2

29. Map showing simulated water-level altitudes at the end of 2057 in the Ozark aquifer for hypothetical scenario 3

30. Graph showing simulated water-level altitude with time at five pumping centers in the model area for hypothetical scenario 3

31. Map showing simulated water-level altitudes at the end of 2057 in the Ozark aquifer for hypothetical scenario 4

32. Graph showing simulated water-level altitude with time at five pumping centers in the model area for hypothetical scenario 4

33. Map showing simulated water-level altitudes at the end of 2057 in the Ozark aquifer for hypothetical scenario 5 .

34. Graph showing simulated water-level altitude with time at five pumping centers in the model area for hypothetical scenario 5.

35. Map showing zones used in the Ozark aquifer (layer 4) for zone-budget analyses

\section{Tables}

1. Description of hydrogeologic units in the model area ...................................................

2. Reported hydrologic property values for the model area and vicinity ..............................9

3. Stress periods, pumping rates, and water-level observations ..........................................16

4. Estimated and simulated flow from groundwater to select river segments in the

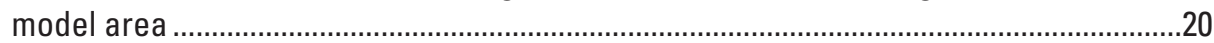

5. Springs specified in layer 2 (Springfield Plateau aquifer) ...............................................21

6. Hydrologic property values specified in the calibrated model ..........................................27

7. Sensitivity of model to changes in parameter values within the Ozark aquifer and

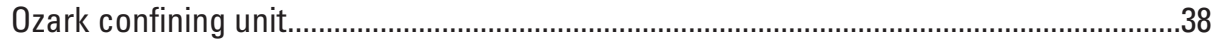

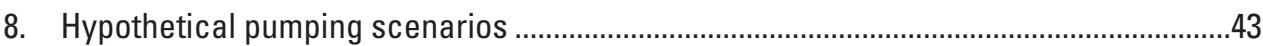

9. Decline in water-level altitude from simulated predevelopment conditions to the end of 2057 at five pumping centers in the Ozark aquifer based on the hypothetical pumping scenarios

10. Flow budget for zone 1 (Kansas section of the model) in the Ozark aquifer (layer 4) for each of the five hypothetical scenarios to the end of 2057

11. Flow budget for zone 2 (Oklahoma section of the mode) in the Ozark aquifer (layer 4) for each of the five hypothetical scenarios to the end of 2057

12. Flow budget for zone 3 (Missouri and Arkansas section of the mode) in the Ozark aquifer (layer 4) for each of the five hypothetical scenarios to the end of 2057. 


\section{Conversion Factors}

\begin{tabular}{lcl}
\hline \multicolumn{1}{c}{ Multiply } & \multicolumn{1}{c}{ By } & \multicolumn{1}{c}{ To obtain } \\
\hline inch (in.) & Length & \\
foot (ft) & 0.0254 & meter $(\mathrm{m})$ \\
mile (mi) & 0.3048 & meter $(\mathrm{m})$ \\
foot per mile (ft/mi) & 1.609 & kilometer $(\mathrm{km})$ \\
\hline & 0.1894 & meters per kilometer $(\mathrm{m} / \mathrm{km})$ \\
\hline square mile $\left(\mathrm{mi}^{2)}\right.$ & Area & \\
\hline & 2.590 & square kilometer $\left(\mathrm{km}^{2}\right)$ \\
\hline foot per day (ft/d) & Flow rate & \\
foot per day (ft/d) & 0.3048 & meter per day $(\mathrm{m} / \mathrm{d})$ \\
cubic foot per second $\left(\mathrm{ft}{ }^{3} / \mathrm{s}\right)$ & 4,383 & inch per year $(\mathrm{in} / \mathrm{yr})$ \\
cubic foot per day $\left(\mathrm{ft}^{3} / \mathrm{d}\right)$ & 0.0283 & cubic meter per second $\left(\mathrm{m}^{3} / \mathrm{s}\right)$ \\
acre-foot per year $(\mathrm{acre}-\mathrm{ft} / \mathrm{yr})$ & 0.0283 & cubic meter per day $\left(\mathrm{m}^{3} / \mathrm{d}\right)$ \\
acre-foot per year $(\mathrm{acre}-\mathrm{ft} / \mathrm{yr})$ & 43,560 & cubic foot per year $\left(\mathrm{ft}^{3} / \mathrm{yr}\right)$ \\
\hline & 119.26 & cubic foot per day $\left(\mathrm{ft}^{3} / \mathrm{d}\right)$ \\
\hline square foot per day $\left(\mathrm{ft}^{2} / \mathrm{d}\right)$ & Transmissivity & \\
\hline
\end{tabular}

Altitude as used in this report refers to distance above the vertical datum and is referenced to the National Geodetic Vertical Daum of 1929 (NGVD of 1929).

Latitude and longitude are referenced to the North American Datum of 1983 (NAD of 1983). 


\title{
Groundwater-Flow Model of the Ozark Plateaus Aquifer System, Northwestern Arkansas, Southeastern Kansas, Southwestern Missouri, and Northeastern Oklahoma
}

\author{
By John B. Czarnecki, Jonathan A. Gillip, Perry M. Jones, and Daniel S. Yeatts
}

\begin{abstract}
To assess the effect that increased water use is having on the long-term availability of groundwater within the Ozark Plateaus aquifer system, a groundwater-flow model was developed using MODFLOW 2000 for a model area covering 7,340 square miles for parts of Arkansas, Kansas, Missouri, and Oklahoma. Vertically the model is divided into five units. From top to bottom these units of variable thickness are: the Western Interior Plains confining unit, the Springfield Plateau aquifer, the Ozark confining unit, the Ozark aquifer, and the St. Francois confining unit. Large mined zones contained within the Springfield Plateau aquifer are represented in the model as extensive voids with orders-of-magnitude larger hydraulic conductivity than the adjacent nonmined zones. Water-use data were compiled for the period 1960 to 2006, with the most complete data sets available for the period 1985 to 2006. In 2006, total water use from the Ozark aquifer for Missouri was 87 percent $(8,531,520$ cubic feet per day) of the total pumped from the Ozark aquifer, with Kansas at 7 percent $(727,452$ cubic feet per day), and Oklahoma at 6 percent $(551,408$ cubic feet per day); water use for Arkansas within the model area was minor. Water use in the model from the Springfield Plateau aquifer in 2005 was specified from reported and estimated values as 569,047 cubic feet per day. Calibration of the model was made against average water-level altitudes in the Ozark aquifer for the period 1980 to 1989 and against waterlevel altitudes obtained in 2006 for the Springfield Plateau and Ozark aquifers. Error in simulating water-level altitudes was largest where water-level altitude gradients were largest, particularly near large cones of depression. Groundwater flow within the model area occurs generally from the highlands of the Springfield Plateau in southwestern Missouri toward the west, with localized flow occurring towards rivers and pumping centers including the five largest pumping centers near Joplin, Missouri; Carthage, Missouri; Noel, Missouri; Pittsburg, Kansas; and Miami, Oklahoma.
\end{abstract}

Hypothetical scenarios involving various increases in groundwater-pumping rates were analyzed with the calibrated groundwater-flow model to assess changes in the flow system from 2007 to the year 2057. Pumping rates were increased between 0 and 4 percent per year starting with the 2006 rates for all wells in the model. Sustained pumping at 2006 rates was feasible at the five pumping centers until 2057; however, increases in pumping resulted in dewatering the aquifer and thus pumpage increases were not sustainable in Carthage and Noel for the 1 percent per year pumpage increase and greater hypothetical scenarios, and in Joplin and Miami for the 4 percent per year pumpage increase hypothetical scenarios.

Zone-budget analyses were performed to assess the groundwater flow into and out of three zones specified within the Ozark-aquifer layer of the model. The three zones represented the model part of the Ozark aquifer in Kansas (zone 1), Oklahoma (zone 2), and Missouri and Arkansas (zone 3). Groundwater pumping causes substantial reductions in water in storage and induces flow through the Ozark confining unit for all hypothetical scenarios evaluated. Net simulated flow in 2057 from Kansas (zone 1) to Missouri (zone 3) ranges from 74,044 cubic feet per day for 2006 pumping rates (hypothetical scenario 1) to 625,319 cubic feet per day for a 4 percent increase in pumping per year (hypothetical scenario 5). Pumping from wells completed in the Ozark aquifer is the largest component of flow out of zone 3 in Missouri and Arkansas, and varies between 88 to 91 percent of the total flow out of zone 3 for all of the hypothetical scenarios. The largest component of flow into Oklahoma (zone 2) comes from the overlying Ozark confining unit, which is consistently about 45 percent of the total. Flow from the release of water in storage, from general-head boundaries, and from zones 1 and 3 is considerably smaller values that range from 3 to 22 percent of the total flow into zone 2. The largest flow out of the Oklahoma part of the model occurs from pumping from wells and ranges from 52 to 69 percent of the total. 


\section{Introduction}

The tristate area of Kansas, Missouri, and Oklahoma is experiencing substantial population growth and corresponding increases in municipal, industrial, and rural residential use of water. Most water supplied to city residents for drinking and household use comes from municipal groundwater wells. Water for industrial use primarily comes from wells drilled and owned by small businesses and larger corporations. Many new municipal wells have been drilled in the last decade to keep pace with the expanding population. Rural residents living near towns have been forced to deepen their domestic wells and lower pumps because of declining water levels.

To assess the effect that increased water use is having on the long-term availability of groundwater in the tristate area, the U.S. Geological Survey (USGS), in cooperation with the Kansas Water Office, developed and applied a groundwaterflow model to a model area covering a part of the Ozark Plateaus aquifer system in northwestern Arkansas, southeastern Kansas, southwestern Missouri, and northeastern Oklahoma (fig.1). All municipal and industrial wells, and some residential wells, in the model area are open to the Ozark aquifer, which is $250 \mathrm{feet}(\mathrm{ft})$ to more than $1,000 \mathrm{ft}$ beneath the land surface. A confining unit varying in thickness from 0 to about
$100 \mathrm{ft}$ overlies the Ozark aquifer and impedes groundwater flow between the surficial Springfield Plateau aquifer and the Ozark aquifer in most places. The Springfield Plateau aquifer yields sufficient water for residential use and was used as a source of water to many older domestic wells. Most new wells are cased through the Springfield Plateau aquifer to protect against contamination from surface sources and to utilize the greater yield of the deeper Ozark aquifer. One concern in this area is that many older abandoned wells are open to the Springfield Plateau aquifer and the Ozark aquifer. These wells can be conduits for the transport of contaminated water from the surface (which was mined for lead and zinc in some parts of the model area) and the shallow aquifer into the deep aquifer (Imes and Emmett, 1994).

Population over the model area increased for the period of study, but growth rates were unevenly distributed. From 1970 to 2007, population in the Missouri counties of Jasper, McDonald, and Newton grew by 44, 85, and 69 percent, respectively, whereas the population of the Kansas county of Crawford grew by 2 percent and the population of the Kansas county of Cherokee shrank by 1 percent over the same time period. Ottawa County, Oklahoma, had a population increase of 8 percent from 1970 to 2007 . Total population for these counties was about 287,000 in 2007 with 68 percent of the

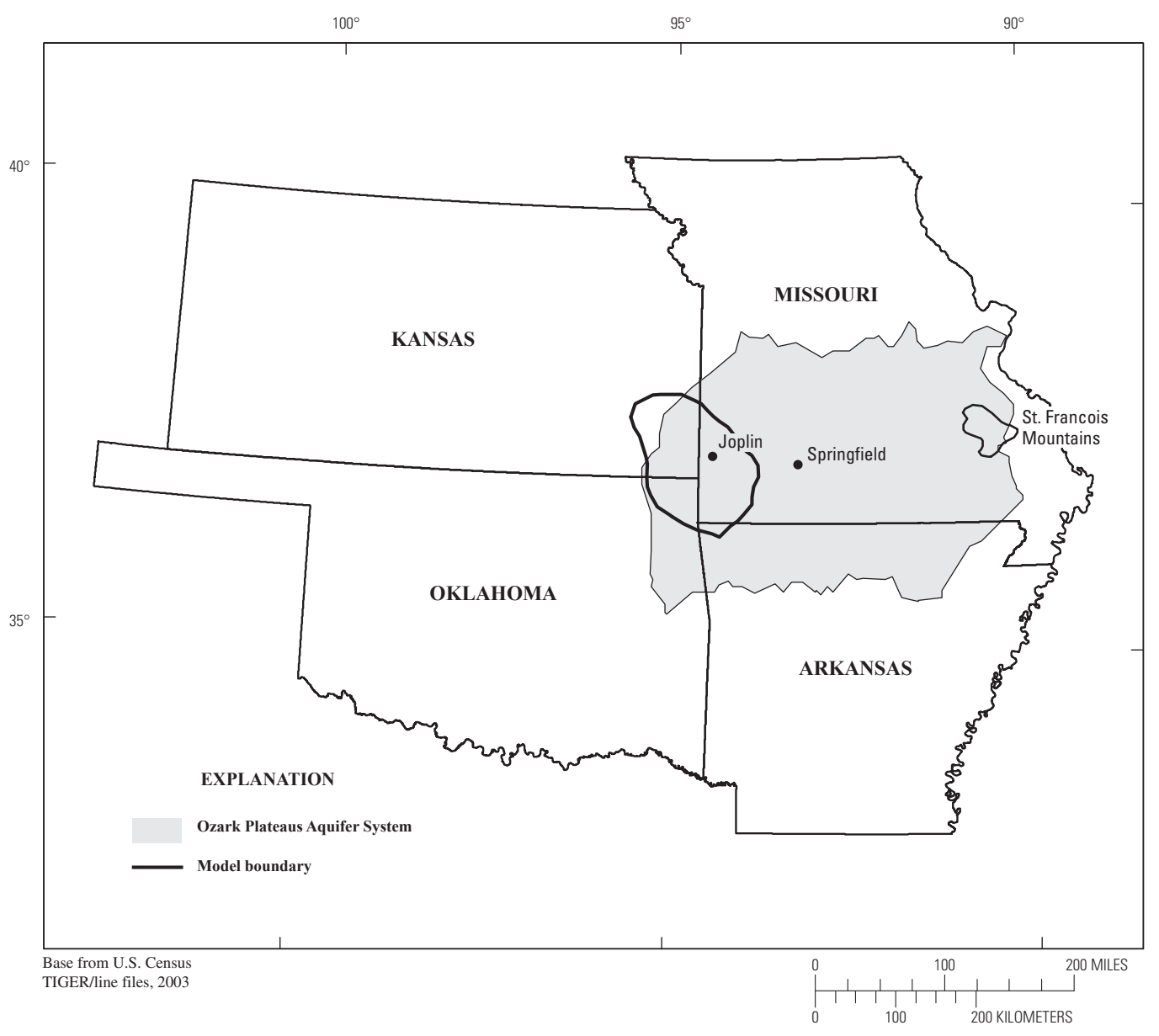

Figure 1. Extent of the Ozark Plateaus aquifer system and location of model area. 
total occurring in Missouri, 21 percent in Kansas, and 11 percent in Oklahoma (Federal Reserve Bank of St. Louis, 2008).

The potential exists that water quality in public supply wells will be degraded and associated with increases in pumping. Water quality of the Ozark aquifer evolves along the generalized west-northwestward flow path from southwestern Missouri to southeastern Kansas. In the east, the water is a calcium-magnesium bicarbonate type with dissolved-solids concentrations of less than $500 \mathrm{mg} / \mathrm{L}$ that gradually changes toward the west to a sodium chloride water type with large dissolved-solids concentrations (greater than 5,000 mg/L) (Macfarlane and Hathaway, 1987; Imes and Emmett, 1994). Naturally occurring large dissolved-solids concentrations near areas experiencing population growth and the increased pumping to meet increased demands associated with the population growth could result in upward or eastward migration of waters with large dissolved-solids concentrations, especially in Kansas. An additional concern in the model area is that many older and abandoned wells are open to both the Springfield Plateau and Ozark aquifers. In areas where the Springfield Plateau aquifer is mineralized, contamination from ore deposits or mining activities (large concentrations of lead, zinc, cadmium, iron, and arsenic) may be drawn into the underlying Ozark aquifer by increased pumping stress in the area. The potential also exists for mineralized water to move downward through areas where the confining unit is more permeable or nonexistent.

\section{Purpose and Scope}

The purpose of this report is to describe a groundwaterflow model that characterizes groundwater-flow direction and rates within the Ozark Plateau aquifer system primarily within the tristate area of Kansas, Missouri, and Oklahoma. This is accomplished by: (1) describing the development and calibration of a groundwater-flow model used to simulate groundwater flow within the Springfield Plateau and Ozark aquifers; (2) describing the simulated effects to future groundwater levels resulting from various hypothetical pumping scenarios using the calibrated model; and (3) using the groundwater-flow model to evaluate flow rates and percentages in and out of zones specified in the model for various water-use scenarios. The scope of the study is limited to the part of the Ozark Plateaus aquifer system located in northwestern Arkansas, southeastern Kansas, southwestern Missouri, and northeastern Oklahoma.

\section{Previous Investigations}

Numerous investigations have been made of the geology and hydrology of the tristate mining district with particular emphasis on Ottawa County, Oklahoma, with its extensive mining of lead and zinc ore. Reed and others (1955) conducted an extensive investigation of the groundwater resources of Ottawa County, which included aquifer test data for the
Roubidoux Formation and pumping data for the Boone Formation. McKnight and Fischer (1970) extensively discussed the geology and mining history of the lead and zinc mines. Marcher and Bingham (1971) described the water resources of much of northeastern Oklahoma. Playton and others (1980) conducted a study of the water within the abandoned lead and zinc mines in the region. Conceptualization of the flow system of the Ozark Plateau aquifer system and assessment of the water quality therein is contained in Macfarlane and others (1981), Macfarlane and Hathaway (1987), and Adamski and others (1995). Marcher and others (1984) reported on the hydrology of the coal area encompassing the model area. Luza (1986) evaluated problems related to mine collapses. Parkhurst (1987) reported on the chemical constituents found in water from Tar Creek and the Picher mining area. Spruill (1987) assessed water resources including water levels in the northern part of the model area. DeHay and others (2004) assessed groundwater and surface-water altitudes and chemical constituents in the mined area in 2002 to 2003.

Water availability has been a concern within the model area. A hydrologic study for the city of Springfield, Missouri, located outside the eastern edge of the model area, included collection of water-use data, historical and current water-level data, and preparation of a groundwater-flow model to predict future groundwater-level declines to provide information needed to make long-term water-management decisions (Imes, 1989). Christenson and others (1994) discussed the geohydrology of the Roubidoux aquifer, conducted an aquifer test, and produced a digital model of the cone of depression of the Roubidoux aquifer in the vicinity of Miami, Oklahoma. Reed and Czarnecki (2006) developed a digital model of groundwater flow of the Boone Formation (part of the Springfield Plateau aquifer) for evaluating the groundwater-flow system of the Tar Creek Superfund Site.

The model area of the current study is contained within the model area for the Central Midwest Regional AquiferSystems Analysis (CMRASA) (Imes and Emmett, 1994). Imes and Emmett (1994) discussed the regional geohydrology and presented a regional scale numerical model. Because of the large scale used in that model, each model cell had an area of 195.3 square miles $\left(\mathrm{mi}^{2}\right)$. The CMRASA model only simulated predevelopment conditions and did not simulate effects of pumping.

Concern over adequate water availability has led to continued studies within the tristate area. A hydrologic modeling study of the Joplin area was conducted (Wittman and others, 2003) to evaluate water-level declines. The resulting model showed effects from groundwater withdrawals in Kansas that were not part of the model calibration, but did not include particle tracking to determine source areas of water to the wells. The model covered approximately one-third of the current model area. Gillip and others (2008) presented potentiometricsurface maps of the Springfield Plateau and Ozark aquifer within the model area constructed from 285 water levels measured in 2006. Macfarlane and others (2005) and Macfarlane (2007) presented details of the location and construction of 
two monitoring wells in southeastern Kansas as well as aquifer test results from two Pittsburg, Kansas, wells completed in 2006 and 2007, which analyzed water-level data recorded in the monitor wells.

\section{Approach}

Construction of a groundwater-flow model of the model area requires the assemblage of hydrogeologic data. These data include: (1) type and spatial distribution of hydrogeologic units within the model area, (2) distribution of water levels within the hydrogeologic units through time, (3) distribution of surface-water sources and observed flow rates, (4) locations and rates of groundwater pumping through time, (5) land-surface altitudes, (5) surficial recharge estimates, and (6) estimates of hydraulic properties of hydrogeologic units.

Hydrogeologic units were compiled largely from the model of Imes and Emmett (1994). Digital representations of the altitudes of the tops of the hydrologic units were developed from that model for importing into the current model grid. Land-surface data were developed from USGS Digital Elevation Model (DEM) data.

Water-level data from wells were compiled for the model area to assess water-level trends and groundwater-flow direction, and to establish water-level observations on which to base model calibration. Well-construction and depth data were evaluated to establish the aquifer contributing water to each observation well. Water-level data collected by State agencies (Kansas Geological Survey (KGS), Missouri Department of Natural Resources, and Oklahoma Department of Environmental Quality) were evaluated to establish data gaps, which were filled in, where possible, by field reconnaissance by USGS personnel from the Kansas, Missouri, and Oklahoma Water Science Centers. Potentiometric-surface maps of the Springfield Plateau aquifer and Ozark aquifer were developed using data by Gillip and others (2008).

Surface-water sources were identified from geospatial data for major rivers and lakes in the study area. Altitudes of rivers represented in the model were obtained from DEM data. Base-flow rates for river reaches were estimated from USGS streamflow data.

An important component of the groundwater-flow model is the distribution and rates of groundwater use with time. Water-use data were compiled for the period 1985 to 2006 from USGS and various State and local water agencies.

Areal recharge estimates within the model area were compiled from reported values. These values were modified during model calibration as one set of variables to reduce the difference between simulated and observed water-level altitudes and river flows.

Hydraulic properties of hydrogeologic units were compiled from all available sources for use as initial estimates in the model. Values subsequently were modified during model calibration to reduce the difference between simulated and observed water-level altitudes and river flows.
Once all available hydrogeologic data were assembled, a conceptual model of the flow system was developed based on these data that describes the general direction of groundwater flow from sources to sinks within the study area. After a conceptual model of the flow system was developed, a digital model of groundwater flow was constructed using the Groundwater Modeling System (GMS) (Aquaveo, 2008), which embodies MODFLOW 2000 (Harbaugh and others, 2000). Hydrogeologic data were specified within the model through the GMS graphical user interface, and hydrologic-boundary conditions were specified in accordance with the conceptual model. Calibration of the model was performed so that the difference between observed and simulated water levels and observed and simulated flows to or from rivers and springs was minimized. The calibrated model then was used for simulating response of the flow system to various hypothetical pumping stresses. Results from the simulations were used to assess groundwater-flow direction and magnitude, changes in water-level altitudes, and changes in storage.

\section{Acknowledgments}

During the course of this study, a Technical Advisory Committee (TAC) met periodically to discuss various aspects of the model, to offer helpful guidance and review, and to keep members abreast of study progress and other relevant work in the study area. TAC members were also given the opportunity to provide technical review comments to an earlier draft of this report. Members of the TAC (in alphabetical order) included: Walter Aucott (Chairman, USGS Kansas Water Science Center); Mark Becker (USGS Oklahoma Water Science Center); Ione Branscum (Kansas Water Office); John Czarnecki (USGS Arkansas Water Science Center); Bob Kirby (Kansas Rural Water Association); Allen Macfarlane (Kansas Geological Survey); Noel Osborne (Oklahoma Water Resources Board); Sam Perkins (Kansas Department of Agriculture, Division of Water Resources); Peter Rausch (city of Monet, Missouri); John Schumacher (USGS Missouri Water Science Center), and James Vandike (Missouri Department of Natural Resources).

Compilation of water-use data was facilitated by Terry Holland, Joan Kenny, Robert Tortorelli, Richard Huizinga, Brenda Smith, and Doug Mugel (all with the USGS), Shannon Erissman (Missouri Department of Natural Resources), and Richard Kiwala (Missouri American Water Company). Stratigraphic data for hydrogeologic units used in the model were provided in digital format by Joe Richards (USGS).

\section{Description of Model Area}

The model area (fig. 2) covers 7,340 $\mathrm{mi}^{2}$ in northwestern Arkansas, southeastern Kansas, southwestern Missouri, and northeastern Oklahoma. Generally, the topography in the model area is low relief prairie in the west and northwest with greater relief in the southeast. Land-surface altitude within the model area ranges from about $650 \mathrm{ft}$ to about $1,320 \mathrm{ft}$, and 


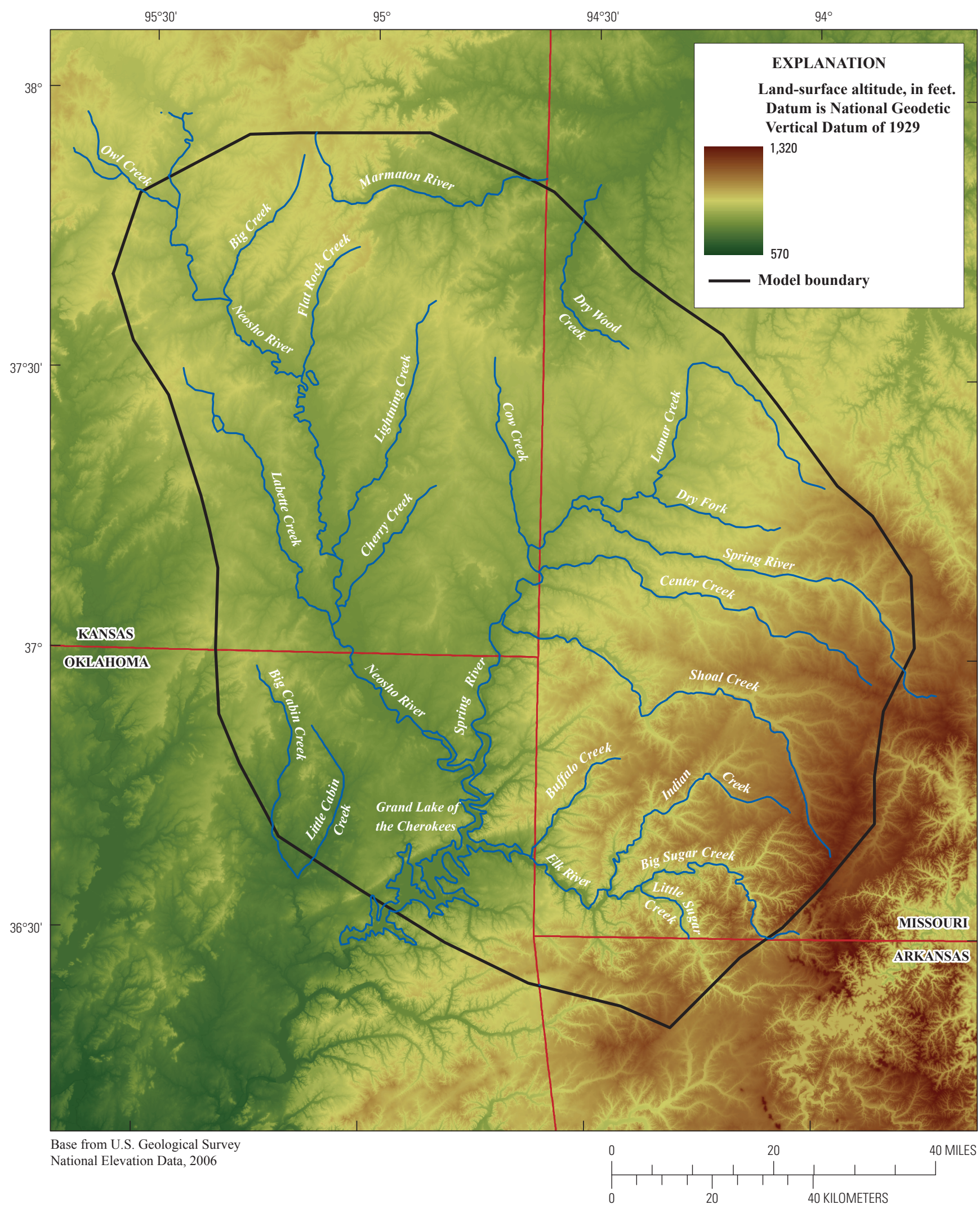

Figure 2. Topography and rivers in model area. 
slopes generally from the southeast toward the west in the southern part of the model area, and locally toward river drainages and Grand Lake of the Cherokees. Topographic relief is largest in the higher-altitude areas in the Missouri part of the model area (fig. 2).

Average annual precipitation in the region during 19712000 was 46.01 inches at Pittsburg, Kansas; 46.07 inches at Joplin, Missouri; 43.89 inches at Miami, Oklahoma;, and 46.01 inches at Fayetteville, Arkansas (National Climatic Data Center, 2008a, 2008b, 2008c, 2008d). Population centers within the model area include Pittsburg, Kansas; Joplin, Missouri; Carthage, Missouri; and Miami, Oklahoma (fig. 3).

Groundwater flow within the model area occurs generally from the highlands of the Springfield Plateau in southwestern Missouri toward the west, with localized flow occurring towards rivers and pumping centers including the five largest pumping centers near Joplin, Missouri; Carthage, Missouri; Noel, Missouri; Pittsburg, Kansas; and Miami, Oklahoma. The lateral boundaries of the model were selected partly to coincide with topographic divides that separate drainage basins, and by major faults (Chesapeake and Greasy Creek Faults) located on the margins of the model area. The model area was extended to include all of the moratorium area designated by the State of Kansas to include the area shown on figure 3. This area has a moratorium placed on additional water-well construction until assessment of future effects on groundwater resources are available (Kansas Water Office, 2007). Values of horizontal hydraulic conductivity, or horizontal anisotropy, may be larger along the axis of the Miami Syncline (fig. 3) because of fracturing. Fracturing along the Miami Syncline (fig. 3) may have contributed to hydrothermal deposits of lead and zinc ore (McKnight and Fischer, 1970, p. 142-145). Preferential flow caused by anisotropy also may occur along the axis of the Miami Syncline, although hydraulic data that would support this concept are lacking.

\section{Hydrogeologic Setting of the Ozark Plateaus Aquifer System}

The Springfield Plateau aquifer and the Ozark aquifer are part of the Ozark Plateaus aquifer system, which is divided into five primary hydrogeologic units (fig. 4; table 1). The hydrogeologic units are distinguished by rocks with similar hydrologic properties, which usually coincide with formation boundaries and can span several geologic time systems. The formations that make up the Ozark Plateaus aquifer system range from Mississippian to Cambrian age. The five hydrogeologic units from youngest to oldest are the Springfield Plateau aquifer, the Ozark confining unit, the Ozark aquifer, the St. Francois confining unit, and the St. Francois aquifer (Imes and Emmett, 1994). Overlying the Ozark Plateaus aquifer system is the Western Interior Plains confining system, consisting of less permeable sediments of Pennsylvanian to Mississippian age. Underlying the Ozark Plateaus aquifer system is the basement confining unit, consisting primarily of igneous rocks of Precambrian age. These hydrogeologic units and their members are discussed in detail in Imes and Emmett (1994). A brief discussion of the hydrogeologic units in the model area follows.

\section{Western Interior Plains Confining Unit}

The Western Interior Plains confining unit overlies the Springfield Plateau aquifer and is exposed at the surface in the northwestern half of the model area, capping the Ozark Plateaus aquifer system. This confining unit has been removed by erosion in the rest of the model area except for isolated erosional remnants. No other hydrogeologic units exist above the confining system in the model area with the exception of unconsolidated alluvial deposits from rivers. The topography of the surface is characterized by gently rolling hills and broad alluvial valleys. Altitude of the top of the confining unit generally ranges from 800 to $1,000 \mathrm{ft}$.

In the model area, the Western Interior Plains confining unit consists primarily of Pennsylvanian to Upper Mississippian shale, with limestone and sandstone. The less permeable rocks dominate and collectively impede flow to and from the underlying Ozark Plateaus aquifer system. Although, weathered and fractured rock in the upper $300 \mathrm{ft}$ of the confining system can create local groundwater systems of secondary permeability. The thickness of the confining unit increases almost uniformly at a rate of 12 feet per mile ( $\mathrm{ft} / \mathrm{mi}$ ) to the northwest. The thickness ranges from 0 along the southeast eroded boundary to about $1,000 \mathrm{ft}$ in the northwestern corner of the model area.

Hydraulic-test results for the Western Interior Plains confining unit were unavailable for the model area. Imes and Emmett (1994) assigned vertical hydraulic conductivity of 0.002 to 0.009 , and leakance values of $4.3 \times 10^{-6}$ to $4 \times 10^{-4}$ day $^{-1}$ to the Western Interior Plains confining unit in the area of their model that overlaps the current model area (table 2).

Spatial variability in hydrologic-property values within the model area is expected because of the variability in the degree of fracturing of hydrologic units and unit thickness. Hydraulic-test data and estimates of hydrologic properties for the model area and vicinity are listed in table 2. Hydrologicproperty values listed in table 2 were compiled from values obtained from field tests and groundwater-flow models and were used to provide starting values during calibration of the model and to provide a basis of comparison with values obtained during calibration. Hydraulic-test data values are site specific and may vary as a result of the scale of the test. For values of hydraulic conductivity, as the scale of the test increases so do the values of hydraulic conductivity (Rovey and Cherkauer, 1995). 


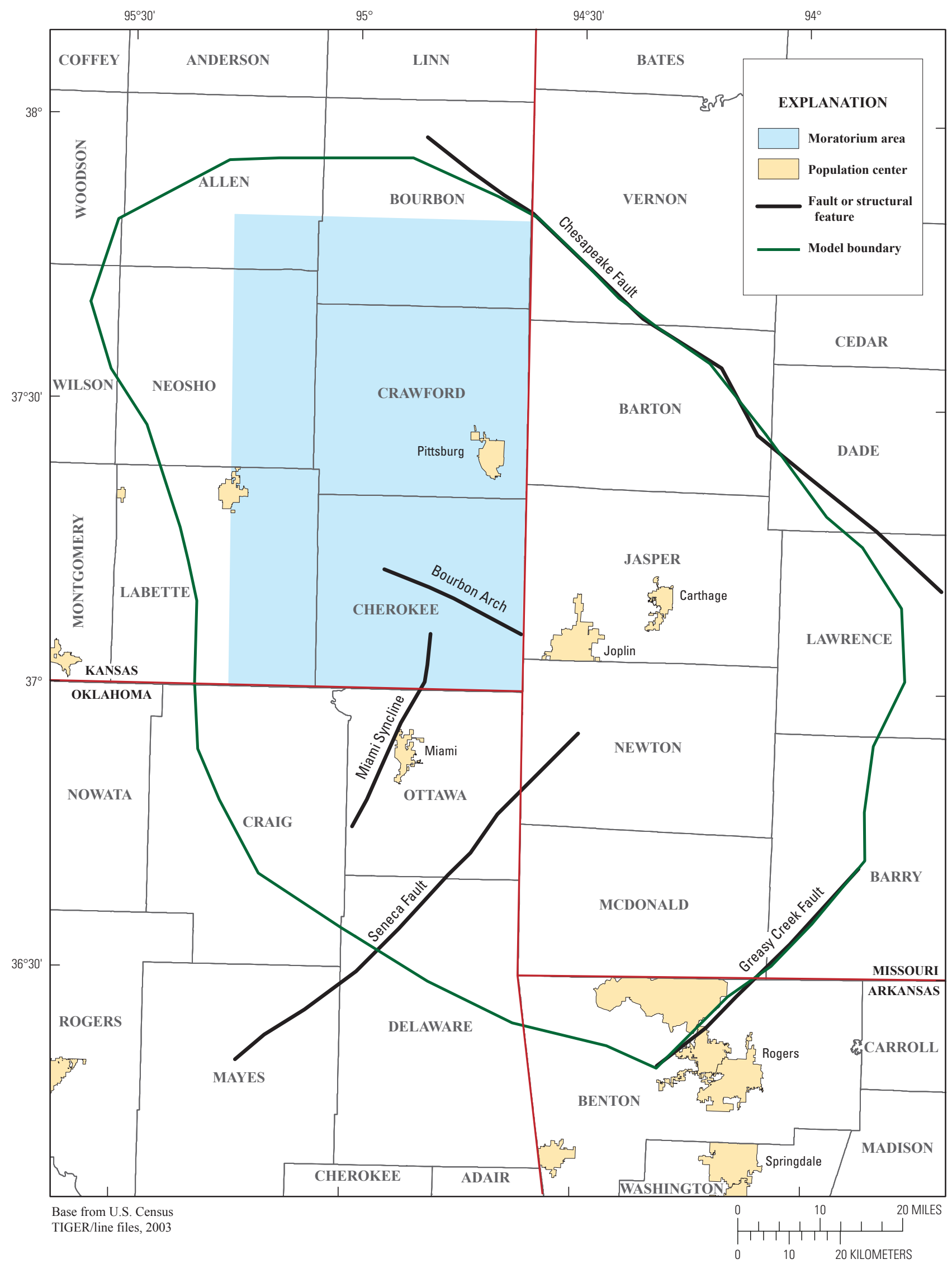

Figure 3. Location of model area, faults, and water-well moratorium area. 


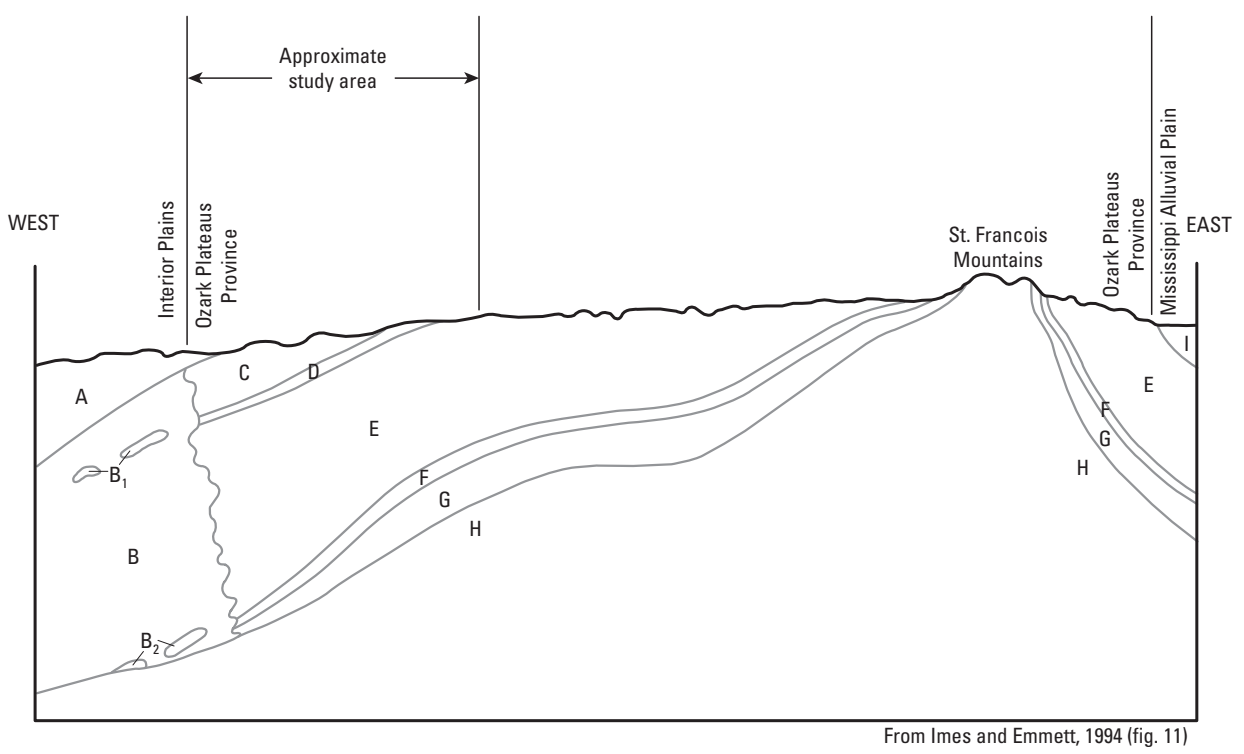

Figure 4. Schematic cross section of the regional hydrogeologic units in and adjacent to the Ozark Plateaus aquifer system.

EXPLANATION
A Western Interior Plains confining system (layer 1)
Ozark Plateau aquifer system
H Basement confining unit
B Western Interior Plains aquifer system
C Springfield Plateau aquifer (layer 2) I Post-Paleozoic sediment
Ozark confining unit (layer3)
$B_{1} \quad$ Stratigraphically equivalent to Ozark confining unit
$\mathrm{B}_{2}$ Stratigraphically equivalent to St. Francois confining unit E Ozark aquifer (layer 4)
F St. Francois confining unit
G St. Francois aquifer

Table 1. Description of hydrogeologic units in the model area.

[--, not represented in model]

\begin{tabular}{|c|c|c|c|c|c|}
\hline System & Hydrogeologic unit & $\begin{array}{l}\text { Hydrogeologic } \\
\text { system }\end{array}$ & Description & $\begin{array}{l}\text { Model } \\
\text { layer }\end{array}$ & $\begin{array}{c}\text { Maximum } \\
\text { thickness } \\
\text { (feet) }\end{array}$ \\
\hline Pennsylvanian & Western Interior Plains & Western Interior Plains & Shale with limestone & 1 & 1,000 \\
\hline Mississippian & Springfield Plateau aquifer & \multirow{6}{*}{$\begin{array}{l}\text { zark Plateaus } \\
\text { aquifer system }\end{array}$} & Limestone and chert & 2 & 400 \\
\hline Devonian & Ozark confining unit & & Shale and limestone & 3 & 100 \\
\hline Silurian & & & & & \\
\hline Ordovician & Ozark aquifer & & $\begin{array}{c}\text { sandstone, chert, } \\
\text { and shale }\end{array}$ & 4 & 1,500 \\
\hline \multirow{2}{*}{ Cambrian } & $\begin{array}{l}\text { St. Francois } \\
\text { confining unit }\end{array}$ & & $\begin{array}{c}\text { Shale, siltstone, } \\
\text { dolostone, and limestone }\end{array}$ & -- & 200 \\
\hline & St. Francois aquifer & & Sandstone and dolomite & -- & 200 \\
\hline Precambrian & Basement confining unit & No system recognized & Rhyolite-granite sequences & -- & Unknown \\
\hline
\end{tabular}




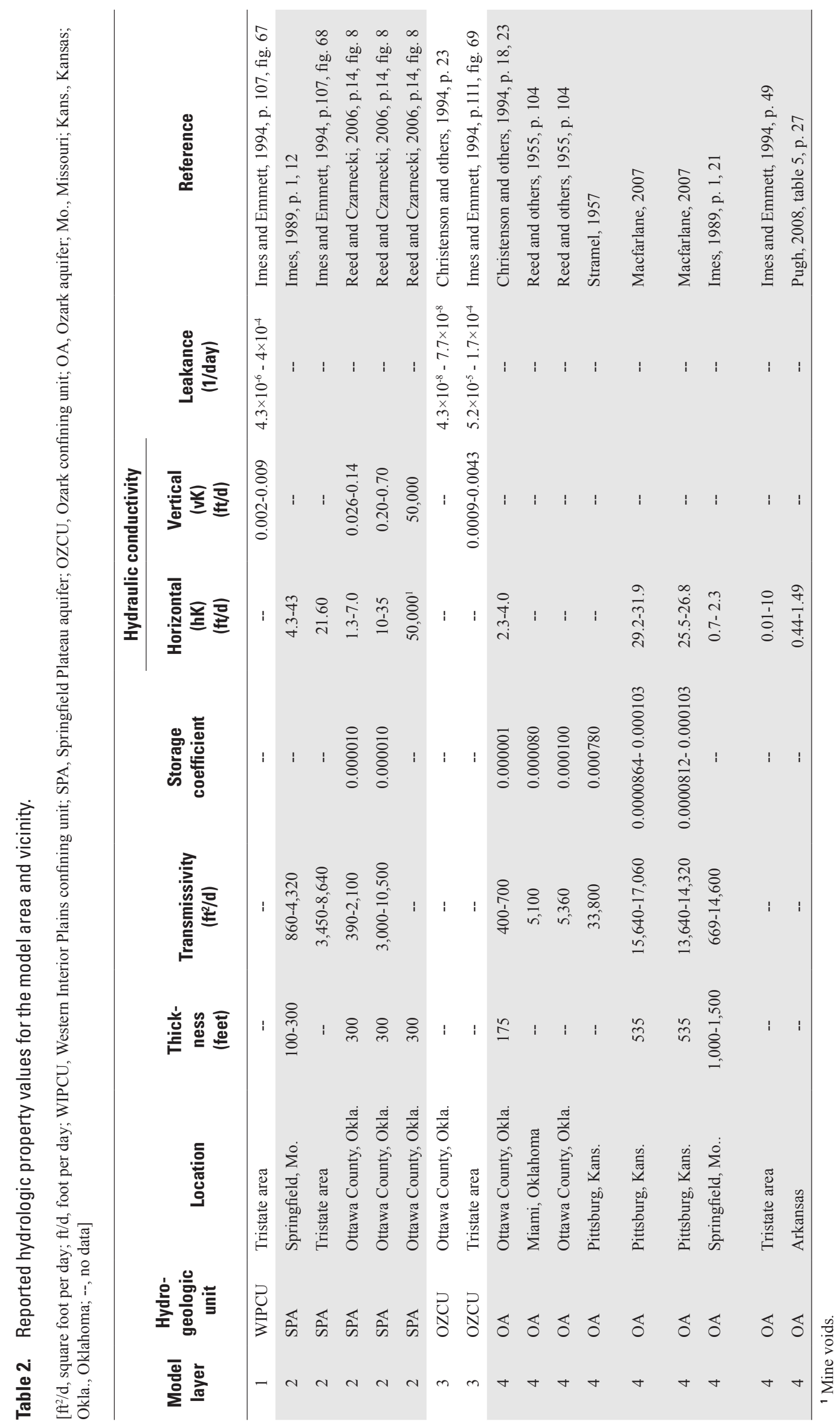




\section{Springfield Plateau Aquifer}

The Springfield Plateau aquifer is the uppermost hydrogeologic unit in the Ozark Plateaus aquifer system, overlying the Ozark confining unit, except in small areas where the Ozark confining unit is absent, where the Springfield Plateau aquifer directly overlies the Ozark aquifer. The Springfield Plateau aquifer is the groundwater aquifer of secondary importance in the model area. It is shallower than the Ozark aquifer, thus more accessible, but the Springfield Plateau aquifer usually produces only enough water for small-scale water users, such as for farms and domestic use. The aquifer consists of limestone of Mississippian age, commonly coarsely crystalline, with locally abundant chert.

The Springfield Plateau aquifer generally dips gently toward the northwest in the model area, except in the south where the dip shifts more southerly. Local dip direction may vary considerably. The aquifer outcrops on the surface throughout most of the southeastern half of the model area, and is overlain by the Western Interior Plains confining system in the rest of the northwestern half of the model area. The Springfield Plateau aquifer is eroded where exposed at the surface. The aquifer is completely absent along some river valleys in Barry and McDonald Counties, Missouri, and Benton County, Arkansas, exposing the Ozark confining unit and Ozark aquifer. The thickness of the aquifer ranges from 0 where absent in the southeastern part of the model area to about $400 \mathrm{ft}$ in several areas throughout the central part of the model area.

In western Missouri and southeastern Kansas, the Keokuk and Burlington Limestones make up most of the aquifer. Both are medium to coarsely crystalline bedded limestone with variable but commonly abundant gray chert, usually in the form of nodules. Solution channels and other karst features are well developed in the upper part of the limestone. Formations in the Springfield Plateau aquifer above and below the Keokuk and Burlington Limestones are not as thick and do not have well developed solution channels. Overlying formations may also contain bedded shale (Frick, 1980).

In northeastern Oklahoma, the aquifer is composed of the Moorefield Formation, the Keokuk Limestone, and the Boone Formation. The Moorefield Formation varies in lithology from limestone to siltstone and shale and is not very permeable. The Keokuk Limestone and the Boone Formation are lithologically similar to the Keokuk and Burlington Limestones in western Missouri, but karst features are not as well developed. The Keokuk Limestone and the Reeds Spring Member of the Boone Formation have substantial chert content that increases from west to east (Imes and Emmett, 1994). The Boone Formation is a coarsely crystalline limestone with interbedded chert, which increases from west to east. The Boone formation can occur as a highly fractured limestone with dissolution occurring along fractures, resulting in increased secondary porosity (Imes, 1989). In northern Arkansas, the Springfield Plateau aquifer is represented by the Boone Formation with a thickness of less than $400 \mathrm{ft}$ (Imes and Emmett, 1994).
Persistent chert layers within the Boone Formation often create perched aquifers. Springs are common where the Boone Formation outcrops in Arkansas.

The Boone Formation yields as much as 750 gallons per minute (Christenson and others, 1994, p. 6). Efforts to dewater the Boone Formation in Ottawa County, Oklahoma to enable mining in 1932 resulted in an average of about 1,730,000 cubic feet per day $\left(\mathrm{ft}^{3} / \mathrm{d}\right.$ of water (about 20 cubic feet per second $\left(\mathrm{ft}^{3} / \mathrm{s}\right)$ being pumped (Reed and others, 1955, p. 53). The hydrologic properties of carbonates, such as those in the Boone Formation, will vary greatly, particularly because of post-depositional erosion and fracturing.

Estimates of horizontal and vertical hydraulic conductivity for carbonate rocks within the model area are sparse. Freeze and Cherry $(1979$, p. 29) provide general ranges of hydraulic conductivity from about 0.0005 to $0.60 \mathrm{ft} / \mathrm{d}$ for limestones and dolomites and about 0.1 to $2,000 \mathrm{ft} / \mathrm{d}$ for karst limestone.

Imes (1989) specified a horizontal hydraulic conductivity value of 4.3 to $43 \mathrm{ft} / \mathrm{d}$ and a transmissivity value of 860 to $4,320 \mathrm{ft}^{2} / \mathrm{d}$ for the Springfield Plateau aquifer. Imes and Emmett (1994) specified a horizontal hydraulic conductivity value of $21.6 \mathrm{ft} / \mathrm{d}$ for the entire Springfield Plateau aquifer in their model. Reed and Czarnecki (2006) used horizontal hydraulic conductivity values of 1.3 to $35 \mathrm{ft} / \mathrm{d}$, and vertical hydraulic conductivity values of 0.026 to $0.7 \mathrm{ft} / \mathrm{d}$, to simulate the Springfield Plateau aquifer in areas of Ottawa County, Oklahoma. To approximate flow conditions in the mine voids within the Springfield Plateau aquifer, Reed and Czarnecki (2006) specified 50,000 ft/d for vertical and horizontal hydraulic-conductivity values.

\section{Ozark Confining Unit}

The Ozark confining unit is the most important unit in the model area in terms of affecting groundwater levels and how groundwater flows between the Springfield Plateau and Ozark aquifers. It consists of shale and limestone of Early Mississippian to Late Devonian age. The Chattanooga Shale and Northview Shale are the primary confining units within the Ozark confining unit, although the limestone also acts as a confining material when secondary porosity is absent. Generally, the Ozark confining unit is present in most of the model area and impedes flow between the Springfield Plateau and Ozark aquifers. However, the confining unit outcrops and is eroded in the southeastern part of the model area, is very thin or absent in several other areas of the model area, and is more permeable in areas where there is less shale content.

In western Missouri and eastern Kansas, the confining unit dips gently to the west. The unit dips more sharply along the western and southern limits of the Ozark Plateaus aquifer system in Arkansas and Oklahoma (Imes and Emmet, 1994). Within the model area, the thickness of the Ozark confining unit ranges from 0 , where the unit is absent, to about $100 \mathrm{ft}$. The confining unit is exposed at the surface in the southeastern 
part of the model area in Barry and McDonald Counties, Missouri, and Benton County, Arkansas. However, in the area of surface exposures, the confining unit is completely eroded in localized areas, exposing the underlying Ozark aquifer at the surface. The Ozark confining unit thins to less than $10 \mathrm{ft}$ in a band that trends southeast-northwest across the model area from Newton and Jasper Counties, Missouri to Labette County, Kansas (Macfarlane and Hathaway, 1987). This band corresponds to the Bourbon arch, which separates the Forrest City and Cherokee Basins (Imes and Emmett, 1994). Within this band, the confining unit is missing in several small areas. The confining unit gradually thickens to about $100 \mathrm{ft}$ in the northern part of the model area and more abruptly thickens at various isolated spots in the confining unit.

In some areas of the Springfield Plateau Aquifer System, the Ozark confining unit is lithologically complex. In the northern area, limestone is the predominate rock strata with shale still being well represented. There are isolated areas in the northern extent of the Springfield Plateau aquifer system where there is no shale, but in the model area shale is largely present. There are small areas in Benton County, Arkansas, and McDonald County, Missouri, where no shale is present because the confining unit was eroded. The net shale thickness in the Ozark confining unit ranges from 0 to about $80 \mathrm{ft}$, which makes up from 0 to 100 percent of the confining unit. The percentage of shale present varies considerably, especially in areas where the confining unit is thin. Shale content reaches 100 percent in the southern part of the model area, in most of Oklahoma and Arkansas, and the southern counties of Missouri.

Christenson and others (1994) assigned a leakance value in their model of $4.3 \times 10^{-8}$ to $7.7 \times 10^{-8} 1 / \mathrm{d}$ to the Ozark confining unit in Ottawa County, Oklahoma. Imes and Emmet (1994) assigned a vertical hydraulic conductivity value of 0.0009 to $0.0043 \mathrm{ft} / \mathrm{d}$ and a leakance value of $5.2 \times 10^{-5}$ to $1.7 \times 10^{-4} 1 / \mathrm{d}$ to simulate flow through the Ozark confining unit (table 2).

\section{Ozark Aquifer}

The Ozark aquifer is the primary groundwater source used in the model area. The aquifer lies between the Ozark confining unit at its upper surface and the St. Francois confining unit at its base, except where the Ozark confining unit is missing and the Ozark aquifer is in direct hydraulic connection with the overlying Springfield Plateau aquifer. The Ozark aquifer consists of middle Devonian to late Cambrian dolostone, limestone, sandstone, chert, and shale, in order of dominance. The lower part of the unit is most permeable and porous. The Roubidoux Formation is the major waterproducing formation in the model area, although several other formations, such as the lower Gasconade Dolomite, Eminence Dolomite, and Potosi Dolomite, are known to produce water in the Ozark aquifer, particularly in Missouri.

The aquifer generally crops out at the surface in the east, outside of the model area, but small exposures occur in the southeastern part of the model area. Where exposed, the Ozark aquifer is heavily dissected by surface drainage, faults, and fractures (McCracken, 1971). Secondary dissolution of carbonate rock along fractures and bedding planes is well developed in the Ozark aquifer, creating karst features in some areas (Imes, 1989). This is especially true in the eastern part of the model area where the Ozark aquifer outcrops or is closer to land surface.

The Ozark aquifer generally dips to the west in the model area. The unit thickness ranges from about $700 \mathrm{ft}$ in the northwest to $1,500 \mathrm{ft}$ in the southeastern part of the model area (Imes, 1989). The aquifer thins to about $300 \mathrm{ft}$ in the southwestern part of the model area in Oklahoma where there is a structural high in the Precambrian basement rock.

The Ozark aquifer is recharged from runoff and river infiltration in outcrop areas where permeable parts of the aquifer outcrop, generally east of the model area, and from downward flow through the overlying confining unit. Macfarlane (2007) analyzed hydraulic-test data from Pittsburg, Kansas, from which estimates of transmissivity and storage coefficient were calculated. Transmissivity values from those tests ranged from 13,640 to $17,060 \mathrm{ft}^{2} / \mathrm{d}$; storage coefficient values ranged from 0.00008 to 0.0001 . Dividing these values over the 535 -ft thickness of the aquifer yields hydraulic conductivity values ranging from 25.5 to $31.9 \mathrm{ft} / \mathrm{d}$ and storativity values of $1.5 \times 10^{-6}$ and $1.9 \times 10^{-6} \mathrm{ft}^{-1}$ (Macfarlane, 2007). Imes and Emmett (1994) estimated values of hydraulic conductivity as 0.01 to $10 \mathrm{ft} / \mathrm{d}\left(0.1 \times 10^{-6}\right.$ to $\left.100 \times 10^{-6} \mathrm{ft} / \mathrm{s}\right)$ for the part of their model covering the model area for this report (table 2). Mean hydraulic-conductivity values from hydraulic testing of units within the Ozark aquifer in Arkansas ranged from 0.44 to $1.49 \mathrm{ft} / \mathrm{d}$ (Pugh, 2008, table 5, p. 27). Specific-capacity data were initially compiled for the current study, but were rejected for comparison because of the large variability in hydraulicconductivity values. Most wells completed in the aquifer yield between 50 and 100 gallons per minute although some wells may yield as much as 600 gallons per minute (Adamski and others, 1995). In Missouri, wells completed in the upper part of the Ozark aquifer produce water from the Jefferson City Dolomite and Cotter Dolomite, which yield less than fully penetrating wells that also produce water from the Roubidoux Formation, Eminence Dolomite, and Potosi Dolomite. Static water levels in wells completed in the Ozark aquifer typically rise above the top of the Ozark aquifer, except in heavily pumped areas where large cones of depression have formed.

\section{St. Francois Confining Unit}

The St. Francois confining unit lies above the St. Francois aquifer. This unit retards groundwater flow between the overlying Ozark aquifer and the St. Francois aquifer and is treated as an impermeable unit in the model. This confining unit is composed of shale, siltstone, dolostone, and limestone. The unit consists of the Upper Cambrian Doe Run Dolomite, Derby Dolomite, and Davis Formation. 
The St. Francois confining unit occurs only in the subsurface in the model area and is absent in much of northeastern Oklahoma and small parts of adjacent States. In many of the areas where the St. Francois confining unit is absent, the underlying St. Francois aquifer also is absent. Presumably, these are areas where St. Francois deposition did not occur because of the structural highs in the underlying basement strata.

The thickness of the St. Francois confining unit ranges from zero where it is missing in several areas of the southwestern part of the model area to over $200 \mathrm{ft}$ in the northeastern part of the model area. The shale content, mostly from the Davis Formation, ranges from zero in much of Oklahoma and southern Kansas to 40 percent (about $40 \mathrm{ft}$ ) in the southwestern Kansas area of the model (Imes and Emmett, 1994). The percentage of shale in the Davis Formation is used as a measure of the confining effectiveness of the unit. Imes and Emmett (1994) assigned horizontal hydraulic conductivity values of 0.005 to $0.006 \mathrm{ft} / \mathrm{d}$ for the part of their model covering the model area for this report.

\section{St. Francois Aquifer}

The St. Francois aquifer overlies the basement confining unit and is the lowermost hydrogeologic unit of the Ozark Plateau aquifer system. The aquifer is overlain by the St. Francois confining unit. The aquifer is composed of Upper Cambrian poorly sorted sandstone and dolomite from the Bonneterre Dolomite, Reagan Sandstone, and Lamotte Sandstone.

The St. Francois aquifer has not been used as a substantial groundwater source in the model area and because of this is not represented in the current model. It occurs only in the subsurface of the model area. The depth to the top of the aquifer ranges from about 1,500 to 2,000 ft below land surface. The aquifer is absent in parts of northeastern Oklahoma in the model area where the unit has been deposited around a structural high formed by the basement confining unit. The thickness of the aquifer in the model area varies from zero where it is missing in northeastern Oklahoma to about $200 \mathrm{ft}$ in south Barton County, Missouri (Imes and Emmett, 1994).

\section{Basement Confining Unit}

The basement confining unit underlies the St. Francois aquifer and is considered the base of the Ozark Plateaus aquifer system. The unit primarily consists of Precambrian rhyolite-granite sequences that are nearly impermeable. The unit forms the structural base for which subsequent sedimentary units are overlain, and, therefore, affects the presence, thickness, and structure of the overlying units.

The basement confining unit is not exposed in the model area. Outside of the model area, the unit is exposed on structural highs at the St. Francois Mountains, and at small areas in Camden County, Missouri, and Mayes County, Oklahoma.

\section{Conceptual Model of Flow System}

A conceptual model of the flow system was developed to explain flow within the model area, which forms the basis for constructing the digital flow model. The conceptual model is based on annual precipitation, surface topography, properties and distribution of the hydrogeologic units, water-level data and resultant potentiometric-surface maps, hydrologic testing results, hydrochemical data, and previously published interpretations of the flow system. With regard to flow within the model area, the Springfield Plateau aquifer and the Ozark aquifer are the principal water-bearing units. Recharge to hydrogeologic units within the model area occurs from atmospheric precipitation, which infiltrates through the surficial materials of any of the hydrogeologic units that outcrop at land surface. Recharge also occurs through rivers where river stage is higher than the water level in the hydrogeologic unit adjacent to the river. Based on the potentiometric surfaces developed by Gillip and others (2008), discharge from the Springfield Plateau aquifer occurs at rivers, at Grand Lake of the Cherokees, at springs, and at wells. Some water from the Springfield Plateau aquifer flows laterally out of the model area, as well as downward into the Ozark confining unit. Flow into the Ozark aquifer occurs as lateral through-flow from upland areas outside the model area, direct recharge from precipitation or surface streams where the Ozark aquifer occurs at the surface, and downward flow from the overlying Ozark confining unit. Discharge from the Ozark aquifer occurs at wells and as lateral flow out of the model area. Spring discharge from the Ozark aquifer does not occur within its limited outcrop area within the model area.

Structural controls on groundwater flow include faults, which may act as either barriers or conduits to flow, although little or no hydraulic test or water-level data are available to confirm either condition. Although some hydrogeologic units within the flow system are fractured, porous-media flow may be approximated at the model scale. Mines present within the Springfield Plateau aquifer act as conduits to flow on a local scale.

\section{Description of Groundwater-Flow Model}

The following sections provide a description of the groundwater-flow model. The software used, the assumptions that went into the model, and the various components that were specified in the model are discussed.

\section{Groundwater-Modeling Tool}

The USGS finite-difference, three-dimensional, groundwater-flow model MODFLOW-2000 (Harbaugh and others, 
2000 ) as it is embodied in GMS (Aquaveo, 2008) was used as the simulation software for the groundwater-flow model for the model area. MODFLOW-2000 was used to solve finite difference groundwater-flow equation approximations for spatial distributions of hydraulic head over time with certain simplifying assumptions. Hydraulic head is calculated at the center of each model cell and flux is calculated into or out of each cell in the three flow directions (X and Y, horizontal vectors; and Z, vertical vector) across the six cell faces (Pollock, 1994). Because it is efficient and fairly robust, the Preconditional-Conjugate-Gradient (PCG) solver was used to solve the finite-difference equation. The calibrated model was used to simulate groundwater flow in the aquifer and to evaluate the range of plausible values for hydrologic characteristics.

\section{Simplifying Assumptions}

By definition, a model is a simplification of a process or a system. In that regard, all subunits within the Western Interior Plains confining unit, the Springfield Plateau aquifer, the Ozark confining unit, and the Ozark aquifer were combined to form the four layers used in the model. The lateral boundaries of the Springfield Plateau aquifer and the Ozark aquifer were simulated as a general head boundary. The base of the Ozark aquifer was modeled as a no-flow boundary because upward flow into the overlying Ozark aquifer is considered to be minor based on the lithology of the underlying St. Francois confining unit. Groundwater use specified for each stress period was considered to be invariant within that time period. Recharge is considered to be constant over the period of simulation despite variations in seasonal precipitation or longer duration climatic conditions such as drought. Variations in hydraulic conductivity within model cells and across areas of the model are considered to be of negligible importance to the groundwater-flow system. It is assumed that fracture and dissolution openings within the Springfield Plateau aquifer and Ozark aquifer are extensive enough in horizontal and vertical distribution that the hydrogeologic units can be simulated as equivalent porous media for the finite-difference grid spacing used in the model. Wells completed in the Springfield Plateau aquifer or the Ozark aquifer were assumed to be fully penetrating and open to the full thickness of each aquifer.

\section{Model Specifications}

The groundwater-flow model consists of various components. These components include: (1) the finite-difference grid, (2) stress-period discretization, (3) model boundary conditions, and (4) water use. Each of the components will be discussed subsequently.

\section{Finite-Difference Grid}

The model grid was subdivided into a horizontally uniform cell network of 253 rows by 180 columns. Each model cell is $2,631 \mathrm{ft}$ by $2,636 \mathrm{ft}$ on a side or $0.25 \mathrm{mi}^{2}$. The model grid is oriented 45 degrees west of north to minimize the number of model grid cells and to better accommodate structural features like those shown on figure 3. Vertically the grid was divided into four layers of variable thickness. All except the bottom layer are discontinuous in some locations. The topmost layer (layer 1) represents the Western Interior Plains confining unit; layer 2 represents the Springfield Plateau aquifer and mine zones therein; layer 3 represents the Ozark confining unit; and layer 4 represents the Ozark aquifer (fig. 4; table 1). An oblique view of the relative thickness and discontinuity of each of the layers is shown in figure 5. Because of the discontinuous nature of the top three layers and the irregular lateral boundary of the model area, only 105,171 cells are active in the model out of a total of 182,160 cells for the four layers. A plan view of the model (fig. 6) shows the occurrence of the different layer surfaces relative to State and county boundaries. The Kansas part of the model at land surface consists primarily of the Western Interior Plains confining unit, whereas, the Missouri part consists primarily of the Springfield Plateau aquifer, and the Oklahoma part consists of about half of each unit.

The model grid was overlain on land-surface topography in GMS. Land-surface altitude data were derived from USGS DEM 30-m (98.4-ft) data (http://ned.usgs.gov/).

\section{Stress Period Discretization}

The model was calibrated by specifying one steady-state stress period (stress period 1) in which no changes in storage take place, allowing the simulated hydraulic head to come into equilibrium with the specified boundary conditions (table 3 ). No pumping within the Ozark aquifer is specified for stress period 1, although a rate of $94,036 \mathrm{ft}^{3} / \mathrm{d}$ was specified in the Springfield Plateau aquifer to represent water pumped for domestic use. For comparison, a model simulation was made with no pumping specified in either the Springfield Plateau or Ozark aquifers for stress period 1 , which resulted in a mean water-level altitude difference of $0.08 \mathrm{ft}$ over all model cells that indicates pumpage is a minor component of the water budget in stress period 1 and the lack of pumping data for the Ozark aquifer is not a major concern. Subsequent stress periods were specified to correspond to stress periods from 1959 through 2057. Stress periods were specified so that groundwater-pumping rates could be varied appropriately as water use changed with time, and water-level altitude observations were available. 


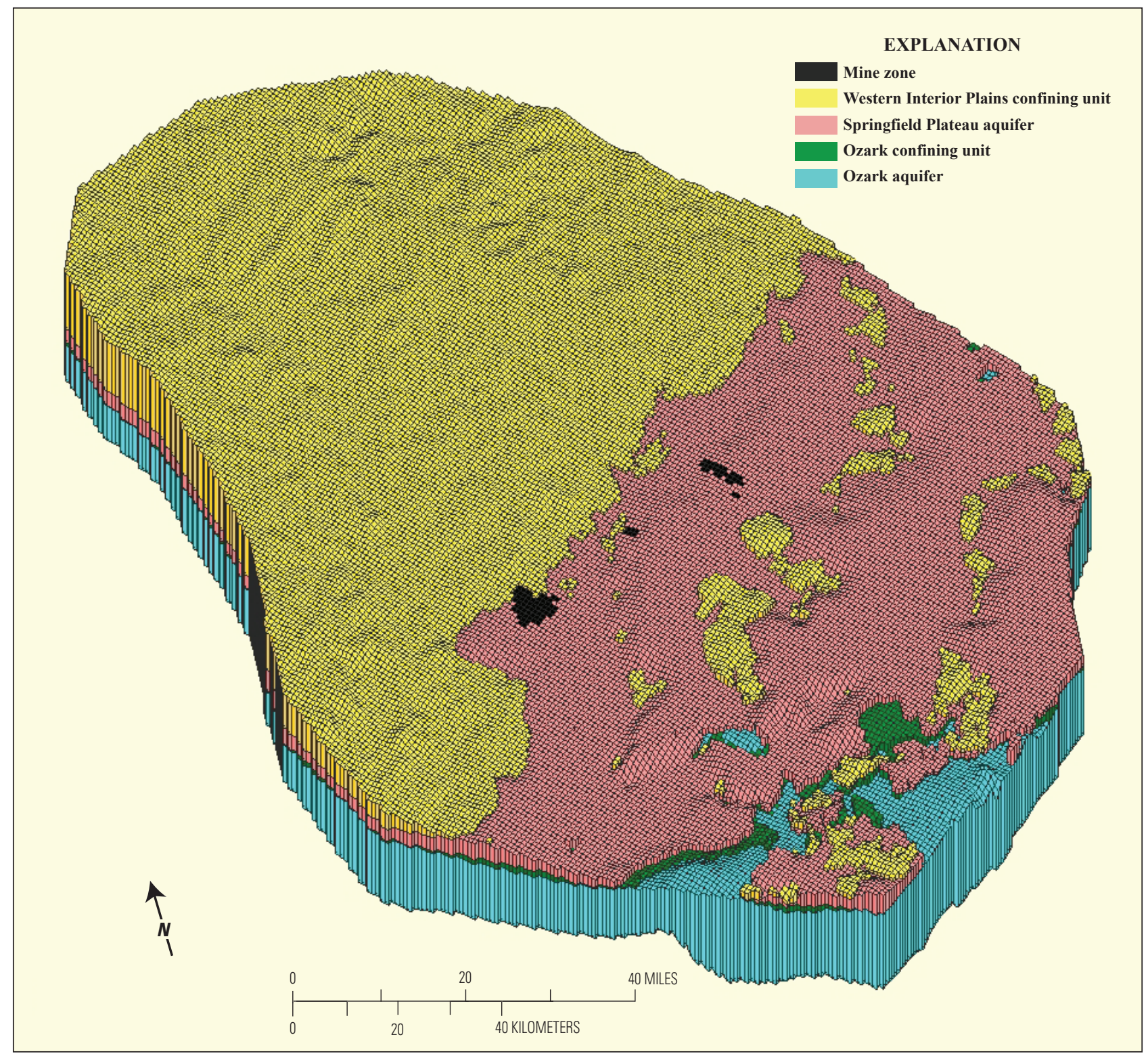

Figure 5. Oblique view of model grid. 


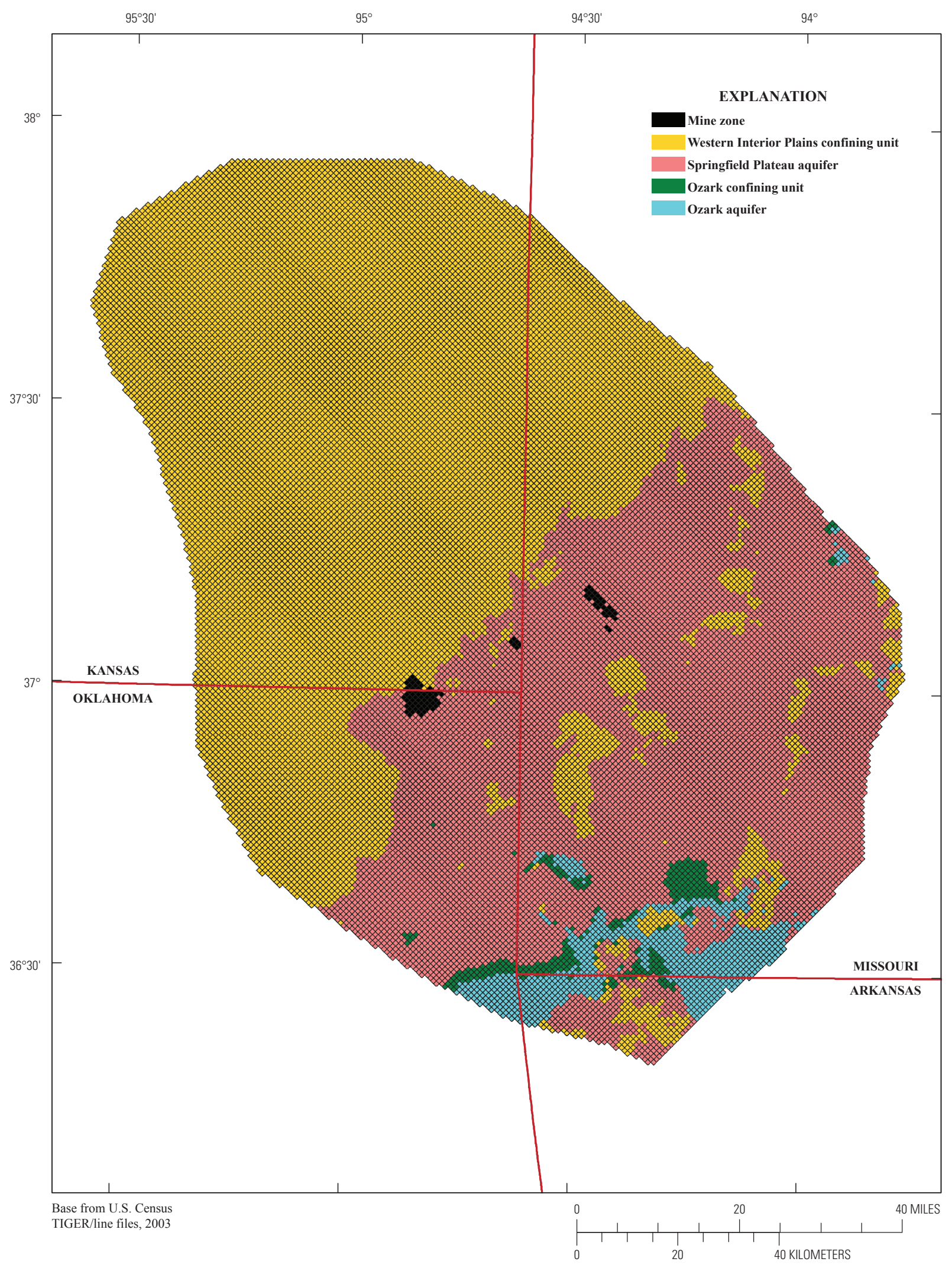

Figure 6. Plan view of model showing layer occurrences at top of the model. 
Table 3. Stress periods, pumping rates, and water-level observations.

[variable, pumping rate varies according to the future scenario tested]

\begin{tabular}{|c|c|c|c|c|c|c|}
\hline \multirow{2}{*}{ Stress period } & \multirow{2}{*}{$\begin{array}{l}\text { Starting } \\
\text { date }\end{array}$} & \multirow{2}{*}{$\begin{array}{l}\text { Length of } \\
\text { stress } \\
\text { period, } \\
\text { (days) }\end{array}$} & \multicolumn{2}{|c|}{$\begin{array}{l}\text { Groundwater-pumping rate } \\
\text { (cubic feet per day) }\end{array}$} & \multicolumn{2}{|c|}{$\begin{array}{l}\text { Number of water level } \\
\text { altitude observations }\end{array}$} \\
\hline & & & $\begin{array}{c}\text { Springfield } \\
\text { Plateau aquifer }\end{array}$ & $\begin{array}{c}\text { Ozark } \\
\text { aquifer }\end{array}$ & $\begin{array}{c}\text { Springfield } \\
\text { Plateau aquifer }\end{array}$ & $\begin{array}{l}\text { Ozark } \\
\text { aquifer }\end{array}$ \\
\hline 1 & $1 / 01 / 1950$ & $3,287^{1}$ & 94,036 & 0 & -- & -- \\
\hline 2 & $1 / 01 / 1959$ & 9,497 & 522,271 & $6,188,233$ & -- & -- \\
\hline 3 & $1 / 01 / 1985$ & 1,826 & 539,387 & $6,678,822$ & -- & 85 \\
\hline 4 & $1 / 01 / 1990$ & 1,826 & 601,567 & $7,172,734$ & -- & -- \\
\hline 5 & $1 / 01 / 1995$ & 1,826 & 472,778 & $6,423,199$ & -- & -- \\
\hline 6 & $1 / 01 / 2000$ & 1,827 & 520,414 & $8,729,119$ & -- & -- \\
\hline 7 & $1 / 01 / 2005$ & 365 & 569,047 & $9,809,398$ & -- & -- \\
\hline 8 & $1 / 01 / 2006$ & 120 & 569,047 & $9,800,494$ & -- & -- \\
\hline 9 & $5 / 01 / 2006$ & 579 & 569,047 & $9,806,172$ & 76 & 119 \\
\hline 10 & $12 / 01 / 2007$ & 3,653 & Variable & Variable & -- & -- \\
\hline 11 & $12 / 01 / 2017$ & 3,652 & Variable & Variable & -- & -- \\
\hline 12 & $12 / 01 / 2027$ & 3,653 & Variable & Variable & -- & -- \\
\hline 13 & $12 / 01 / 2037$ & 3,652 & Variable & Variable & -- & -- \\
\hline 14 & $12 / 01 / 2047$ & 3,653 & Variable & Variable & -- & -- \\
\hline
\end{tabular}

${ }^{1}$ Run to steady state.

\section{Model Boundary Conditions}

Model boundary conditions were specified to permit groundwater flow that would be consistent with the conceptual model developed for the model area. Flux boundary conditions were specified as follows: (1) areally distributed recharge using the $\mathrm{RCH}$ package of MODFLOW, (2) flow to and from rivers using the RIV package of MODFLOW, (3) flow to springs and Grand Lake of the Cherokees by specifying constant-head boundaries at point locations, and (4) lateral flow into and out of the sides of the model within the Springfield Plateau aquifer and the Ozark aquifer using general head boundaries within the GHB package of MODFLOW. Each of these specifications will be discussed in the subsequent sections.

\section{Areally Distributed Recharge}

Areally distributed recharge, resulting from atmospheric precipitation, occurs at land surface (the upper boundary of the model). Precipitation averages between 43.89 and 46.07 inches per year (National Climatic Data Center, 2008a, 2008b, 2008c, 2008d), some of which seeps directly into the Western Plains confining unit, the Springfield Plateau aquifer, and the Ozark aquifer where they occur at land surface. Recharge in the model area to the aquifer is equal to precipitation less (1) runoff into rivers, (2) direct evaporation, and (3) evapotranspiration or direct interception from plants in the soil zone. Areal recharge can vary greatly spatially and is an important model variable for simulating observed water levels. Dugan and Peckenpaugh (1985, p. 70) provide estimates of potential recharge across the model area that ranged from 0.001 to $0.002 \mathrm{ft} / \mathrm{d}$ ( 5 to $10 \mathrm{in} / \mathrm{yr}$ ), generally increasing from northwest to southeast. Their estimates were made on the basis of climate, soil type, slope, land use, and consumptive water use by crops and vegetation. These estimates of recharge were used as starting values during model calibration, and were determined to be much larger than the model would permit without causing water-level altitudes to be excessively high (with reasonable ranges in other parameter values). Areally distributed recharge rates derived after model calibration (fig. 7) are much smaller than the initial estimates used in the model. Values of recharge used in the current model range from 0.00002 to $0.0008 \mathrm{ft} / \mathrm{d}(0.09-3.5 \mathrm{in} / \mathrm{yr})$. In the southern tip of the model, where the Ozark confining unit or Ozark aquifer occurs at or near land surface, or the Springfield Plateau aquifer is thin, no areal recharge was specified. Recharge in that area, which represents about 13 percent of the model area, is accommodated by specification of rivers and the Grand Lake of the Cherokees, and occurs through general-head boundaries specified along the edge of the model (fig. 7).

Recharge values used in the current model (0.00002 to $0.0008 \mathrm{ft} / \mathrm{d})$ are similar to those used in the model of Imes (1989) (0.00031 to $0.00037 \mathrm{ft} / \mathrm{d})$ and Imes and Emmett (1994) (0.00039 ft/d and less). Imes (1989) and Imes and Emmett (1994) tried using larger values of recharge similar to those suggested by Dugan and Peckenpaugh (1985), but note similar 


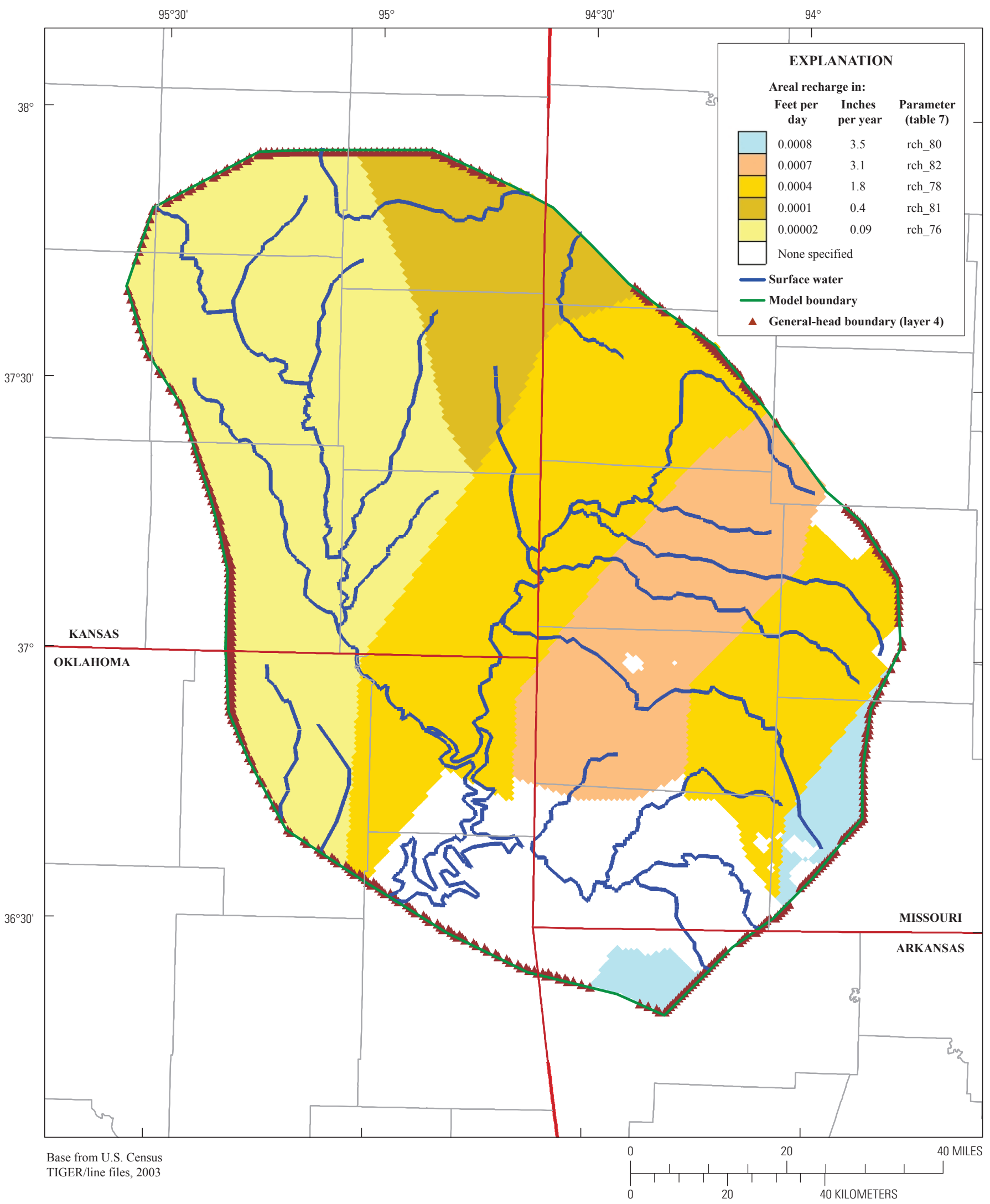

Figure 7. Areally-distributed recharge zones and rates. 
problems of excessively high water-level altitudes when those larger values of recharge were specified. In the Imes (1989, p. 50) model of the Springfield, Missouri, area, a value of 17 percent of the Dugan and Peckenpaugh value for specified recharge was specified. Imes and Emmett (1994, fig. 66) used final values of recharge that were about an order of magnitude smaller than what were interpolated from the Dugan and Peckenpaugh estimates for the same area. Using the watertable fluctuation method (Risser and others, 2005), an estimate of recharge of $0.0002 \mathrm{ft} / \mathrm{d}(0.9 \mathrm{in} / \mathrm{yr})$ was developed using continuous water-level data from the Longview continuousrecording well in McDonald County, Missouri (36.7202 N, $94.2031 \mathrm{~W}$ ) and a specific yield value of 0.003 (Joe Richards, U.S. Geological Survey, written commun., 2009), which are within the range of values used in the current model. Recharge values obtained from the water-table fluctuation method may be considered minimum values.

Because the gridding in the current model is much finer than that used in Imes and Emmett $\left(0.25 \mathrm{mi}^{2}\right.$ compared to $195.3 \mathrm{mi}^{2}$ ), surface topography and simulated flow to rivers within the shallow part of the flow system can be more accurately represented. As Imes and Emmett (1994, p. 99) noted, a large fraction of the recharge from precipitation never enters the deeper, regional groundwater-flow system, but moves rapidly through surficial aquifer material and discharges into rivers. Base-flow estimates from streamflow measurements used as flow observations along with water-level altitude observations in the model allows for more accurate quantification of recharge values. In the model of Reed and Czarnecki (2006), which covered a subset of the current model between the Neosho and Spring Rivers, areal recharge was specified as $0.0011 \mathrm{ft} / \mathrm{d}$ over their entire model area, which was subdivided areally into grid cells of $164 \mathrm{ft}$ by $164 \mathrm{ft}$. By using this finer grid spacing, a larger recharge rate could be specified because smaller order rivers and drains that would accommodate discharge of the additional amount of specified recharge were represented.

\section{Rivers}

Because all model layers occur at land surface, they intersect at least one model river at some point in the model. Thus, a number of rivers (fig. 8) flow within the model area and exchange water with all four layers specified in the model where the layers occur at land surface. The flow of water through riverbeds is dependent on the transmissive properties of the riverbed and the difference between the head in the aquifer and the river stage. Altitudes of the rivers were obtained from USGS DEM data (http://ned.usgs.gov).

The component of groundwater flow to five river reaches (fig. 8) contained within the Neosho River, Spring River, and Shoal Creek was estimated using the difference between 90-percent streamflow durations for gaging stations at upstream and downstream locations on the specific river reach (Hedman and others, 1987; Skelton, 1976) and estimates of 90-percent flow durations for uncontrolled stream locations in Kansas, Oklahoma, and Missouri (Perry and others, 2004) (table 4). Ninety-percent streamflow durations for the gaging stations are streamflow values that were exceeded 90 percent of the time for the period of record (low-flow conditions). The 90-percent durations for the gaging stations were calculated by Skelton (1976) and Hedman and others (1987) using methods that did not include developing base-flow recession curves. The 90-percent flow duration estimates for uncontrolled stream locations were computed from flow-duration information for existing gaging stations with at least 10 years of streamflow record and records through water year (October through September) 2000 (Perry and others, 2004). Ninetypercent flow durations for tributaries contributed flow to the rivers between the upstream and downstream locations were subtracted from the upstream and downstream 90-percent flow duration difference.

\section{Constant-Head Boundaries}

\section{Springs}

Groundwater discharge from springs was simulated using constant-head boundary conditions at selected spring locations. Constant-head boundary conditions allow for the specification of spring-discharge observation points. All springs used as observations discharge from the Springfield Plateau aquifer in Missouri. Flow rates were obtained from Vineyard and Feder (1982). Spring locations used in the model are listed in table 5 and are shown on figure 9 . Springs with measured discharges greater than $100,000 \mathrm{ft}^{3} / \mathrm{d}$ were given preference over smaller springs as observed points of discharge in the model. As a result, many smaller springs reported in Vineyard and Feder (1982) were not included in the model. Areas of the Springfield Plateau aquifer that are unsaturated may contain lenses of perched water above the Ozark confining unit (Imes, 1989). These perched aquifers may result in springs that do not represent the characteristics of regional springs discharging from the Springfield Plateau aquifer. Therefore, it was considered inappropriate to represent small springs in the model. Of these larger discharge springs, not all reported spring discharges were usable because substantial discrepancies exist between reported spring altitude and the altitude derived from land-surface altitude data from digital elevation model data used to construct the model grid.

\section{Grand Lake of the Cherokees}

Grand Lake of the Cherokees is specified as a constanthead boundary with a water-level altitude of $740 \mathrm{ft}$ (U.S. Army Corps of Engineers, 2008). This value was considered to reflect an average long-term minimum pool level of the lake.

\section{General-Head Boundaries}

The general-head boundary package (Winston, 2008) was selected as the boundary condition for moving water into 


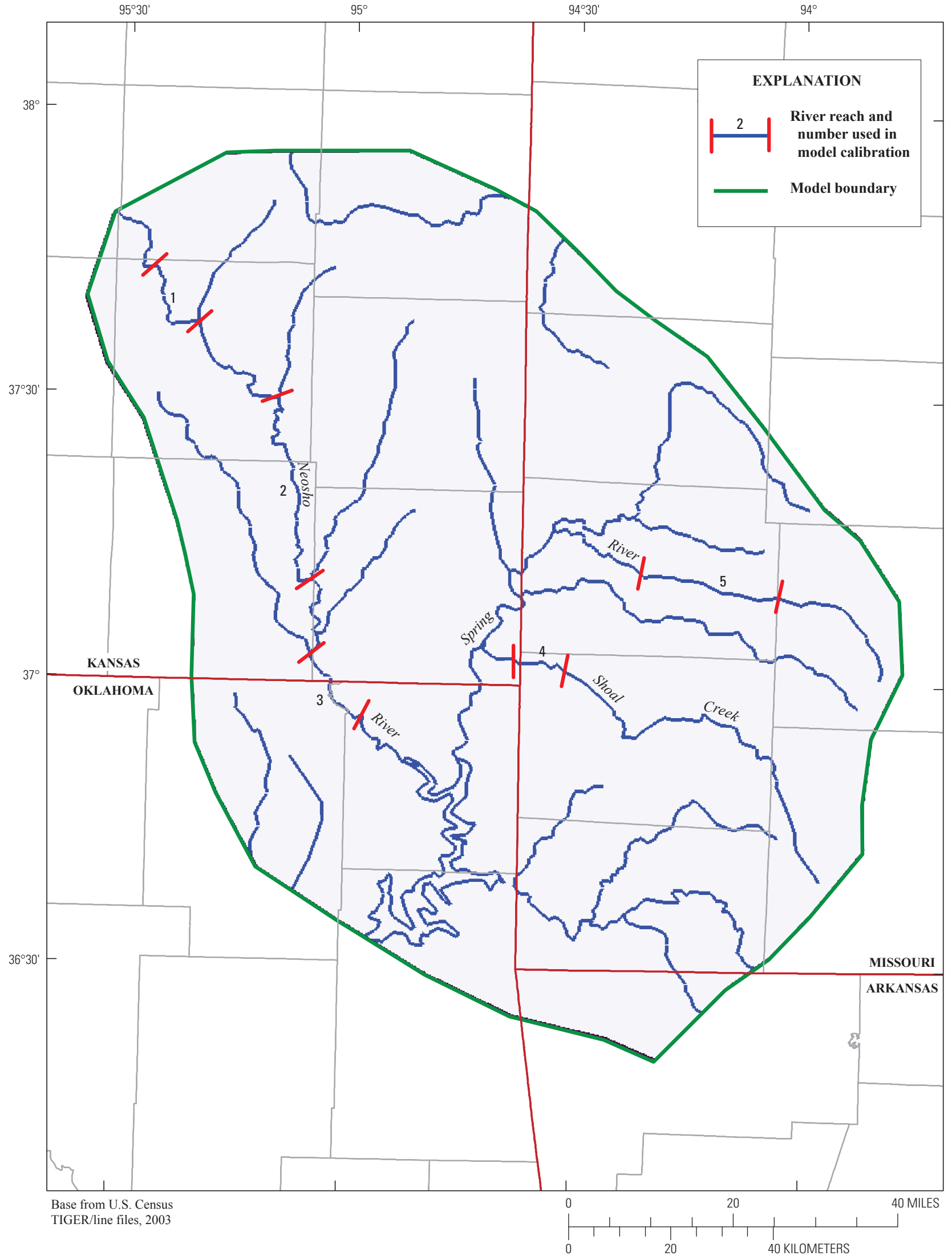

Figure 8. Distribution of rivers and lakes specified in the model. 


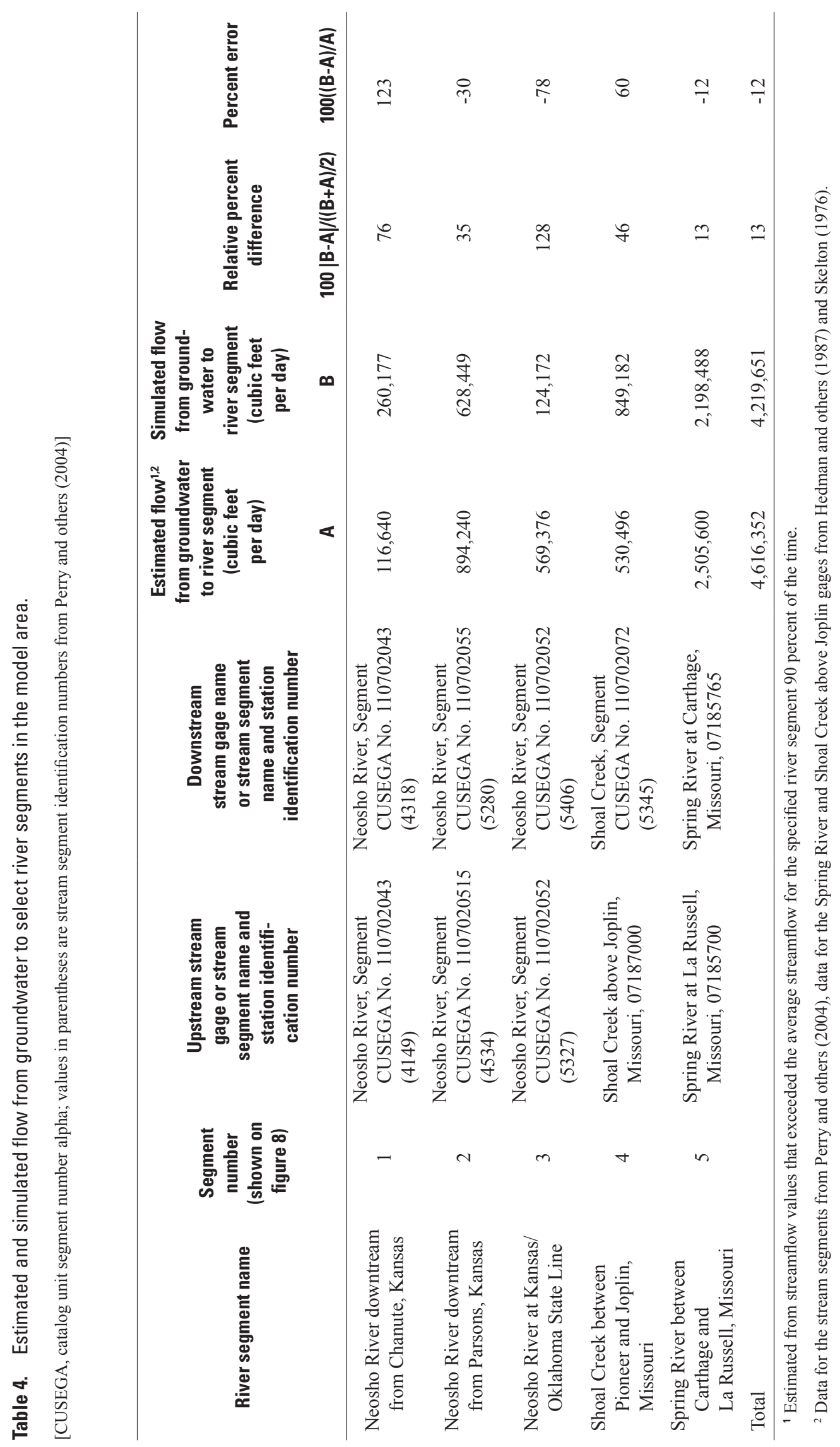




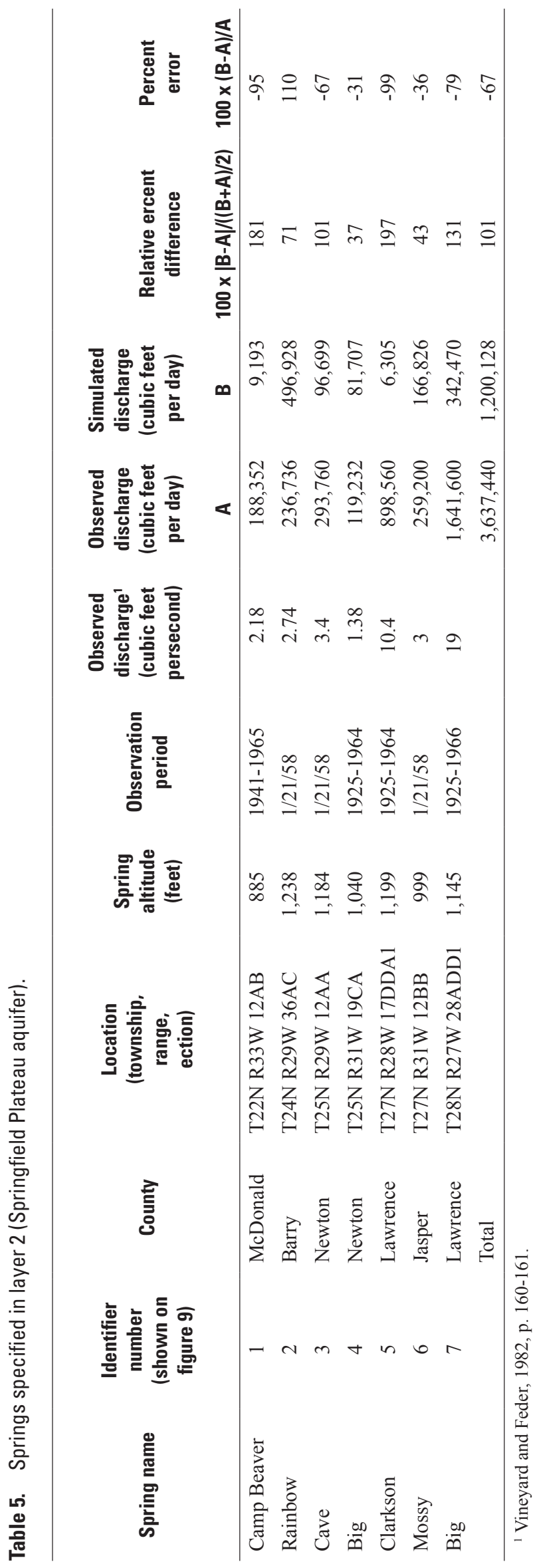




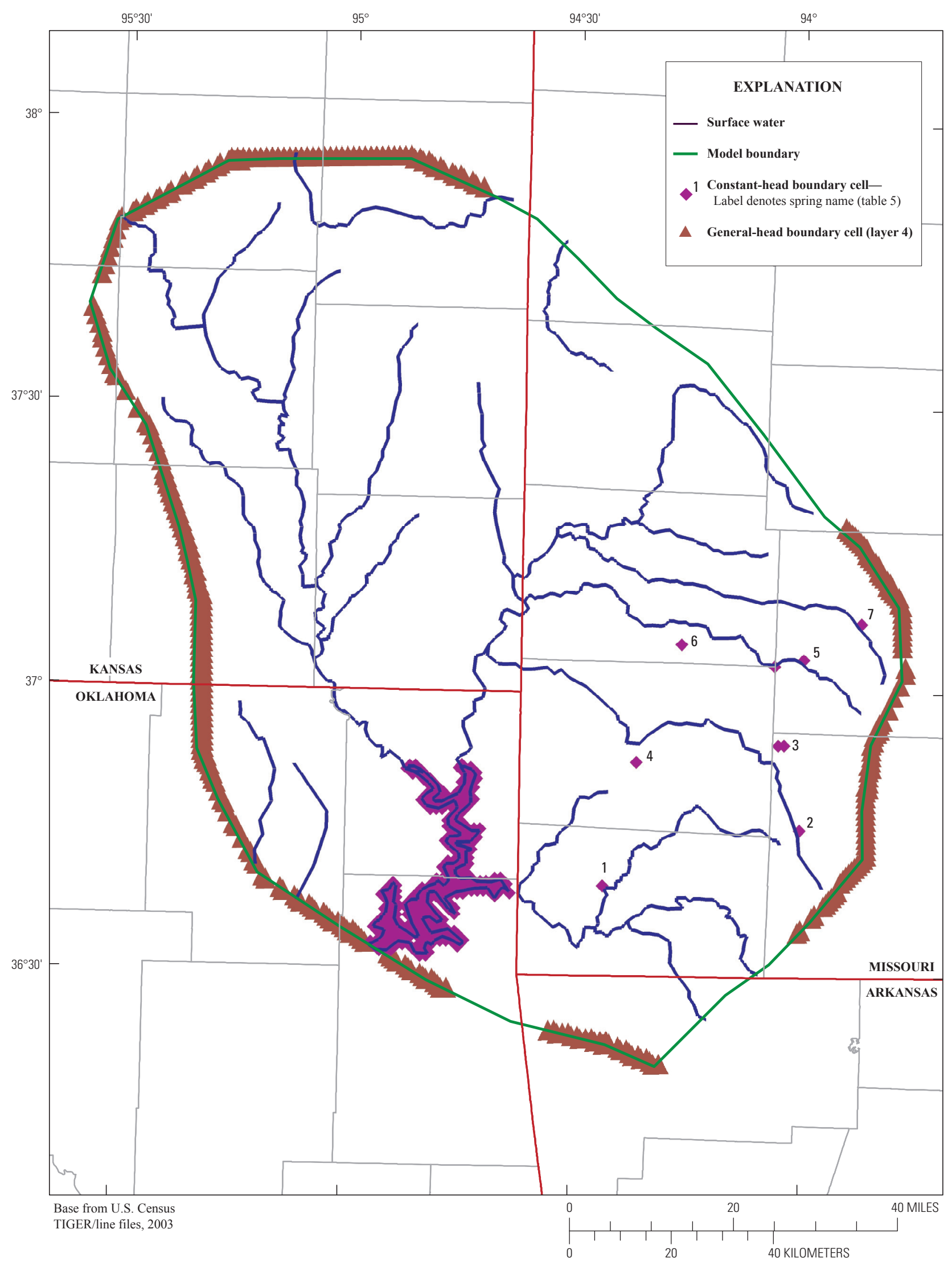

Figure 9. Constant-head and general-head boundary conditions, layer 2 (Springfield Plateau aquifer). 
and out of the outside lateral boundaries of the model. In a general-head boundary, there is a linear relationship between the flux into (or out of) groundwater and the head in the cell. The user specifies a reference head (water-level altitude) and a conductance. When the head in the cell equals the reference head, the flux is zero. If the head in the cell is less than the reference head, water enters the groundwater system through the general-head boundary. If the head in the cell is greater than the reference head, water leaves the groundwater system through the general-head boundary.

General-head boundaries were specified for layer 2 (Springfield Plateau aquifer; fig. 9) and layer 4 (Ozark aquifer; fig. 10). Specified water-level altitudes along the general-head boundaries were derived from measured and inferred water levels (Gillip and others, 2008; U.S. Geological Survey, 2006) in areas where pumping was absent. Boundaries of the model were chosen to be sufficiently distant from pumping centers such as Springfield, Missouri, located about 70 miles east of Joplin, Missouri, for pumping effects on water levels to be minimized. Conductance values range from $20 \mathrm{ft}^{2} / \mathrm{d}$ where model-layer thickness is smallest to $3,400 \mathrm{ft}^{2} / \mathrm{d}$ where modellayer thickness is largest. Where general-head boundary specification is absent, no-flow model boundaries exist. Boundary orientation in these areas is parallel to inferred groundwaterflow paths.

\section{Water Use}

Water-use data were compiled for wells within the model area from each State and USGS Water Science Center in Arkansas, Kansas, Missouri, and Oklahoma for the period 1960 to 2005 . Prior to 1985 , only sporadic reports of values over the entire model area were available. A total of 547 wells that pump from either the Springfield Plateau aquifer (137) or the Ozark aquifer (410) are represented in the model area (fig. 11). Water use is listed by stress period and by aquifer in table 3. Summary water-use data for counties within the model area were compiled from the USGS Aggregate Water Use Data System (AWUDS) for each State (http://water.usgs. gov/watuse/wudata.html). In addition, site-specific data were compiled for individual well sites in Kansas and Oklahoma (Joan Kenny, U.S. Geological Survey, written commun., 2006; Richard Huizinga, U.S. Geological Survey, written commun., 2006). Site-specific data from Kansas (considered to be the most comprehensive of all the States) were not reported consistently until the late 1980s. Because water-use data prior to 1980 were sparse, average water use from 1980 to 1984 was estimated to be the same for the period 1959 to 1985 , allowing for sufficient simulation time for cones of depression in the major pumping centers to develop in the model area. A minor amount of water use from the Springfield Plateau aquifer $\left(94,036 \mathrm{ft}^{3} / \mathrm{d}\right.$ or about 1.4 percent of the total water use specified for 1959) corresponding to domestic users is specified for stress period 1 (predevelopment) but no water use was specified for the Ozark aquifer. The effect that specification of this predevelopment water use had on model fit to observed water-level altitudes and streamflow was evaluated by running the model with a water-use value of zero, and the effect was negligible. Water use in 2005 from the Springfield Plateau aquifer is specified from reported and estimated values as $569,047 \mathrm{ft}^{3} / \mathrm{d}$ (6 percent of the total) and from the Ozark aquifer as 9,809,398 $\mathrm{ft}^{3} / \mathrm{d}$ (94 percent of the total). Major groundwater users and their rates in 2006 are shown in figure 12. In 2006, total water use from the Ozark aquifer for Missouri was 87 percent $\left(8,531,520 \mathrm{ft}^{3} / \mathrm{d}\right)$ of the total water use for the model area, with Kansas at 7 percent $\left(727,452 \mathrm{ft}^{3} / \mathrm{d}\right)$, and Oklahoma at 6 percent $\left(551,408 \mathrm{ft}^{3} / \mathrm{d}\right)$; water use for Arkansas within the model area was minor.

\section{Model Calibration}

Model calibration was performed by adjusting model variables to minimize the difference (residual) between observed and simulated values of water-level altitude and groundwater flow to rivers and springs. Average water-level altitudes from 1980 to 1989 and discrete measurements made in 2006 for the Springfield Plateau aquifer and the Ozark aquifer were used as water-level altitude observations. Model variables that were adjusted manually or through an automated parameter estimation (PEST) procedure include: (1) horizontal and vertical hydraulic conductivity, (2) storage coefficient, (3) specific yield, (4) areally distributed recharge, (5) riverbed conductance, and (6) general-head boundary conductance.

Layers were divided into zones to allow for discrete specification of hydraulic properties within the zones, in part, to reduce residuals (observed minus simulated values of water-level altitude or discharge). For example, if a grouping of water-levelaltitude residuals in an area was generally positive or negative, a new parameter zone might be created around the observation points where those residuals occurred, and parameter values adjusted so that residuals were less biased. Changes to a specific parameter value had the largest effect on observations closest to that parameter zone.

\section{Hydrologic Properties}

Hydrologic-property values specified in the model affect the direction and magnitude of groundwater flow within the model area calibrated. Calibrated values of hydraulic conductivity (horizontal and vertical), specific storage, and specific yield are listed in table 6 for all model zones. The values listed in table 6 are the final values used in the calibrated model after model calibration was completed. Although a layer is assumed to have the same lithology, model zones (fig. 13) were defined, within reasonable hydrogeologic constraints, within a layer so that simulated water-level altitudes could be matched more closely to observed values. Hydrologic-property values (table 6) may vary between zones so that the difference between observed and simulated water-level altitudes is minimized. 


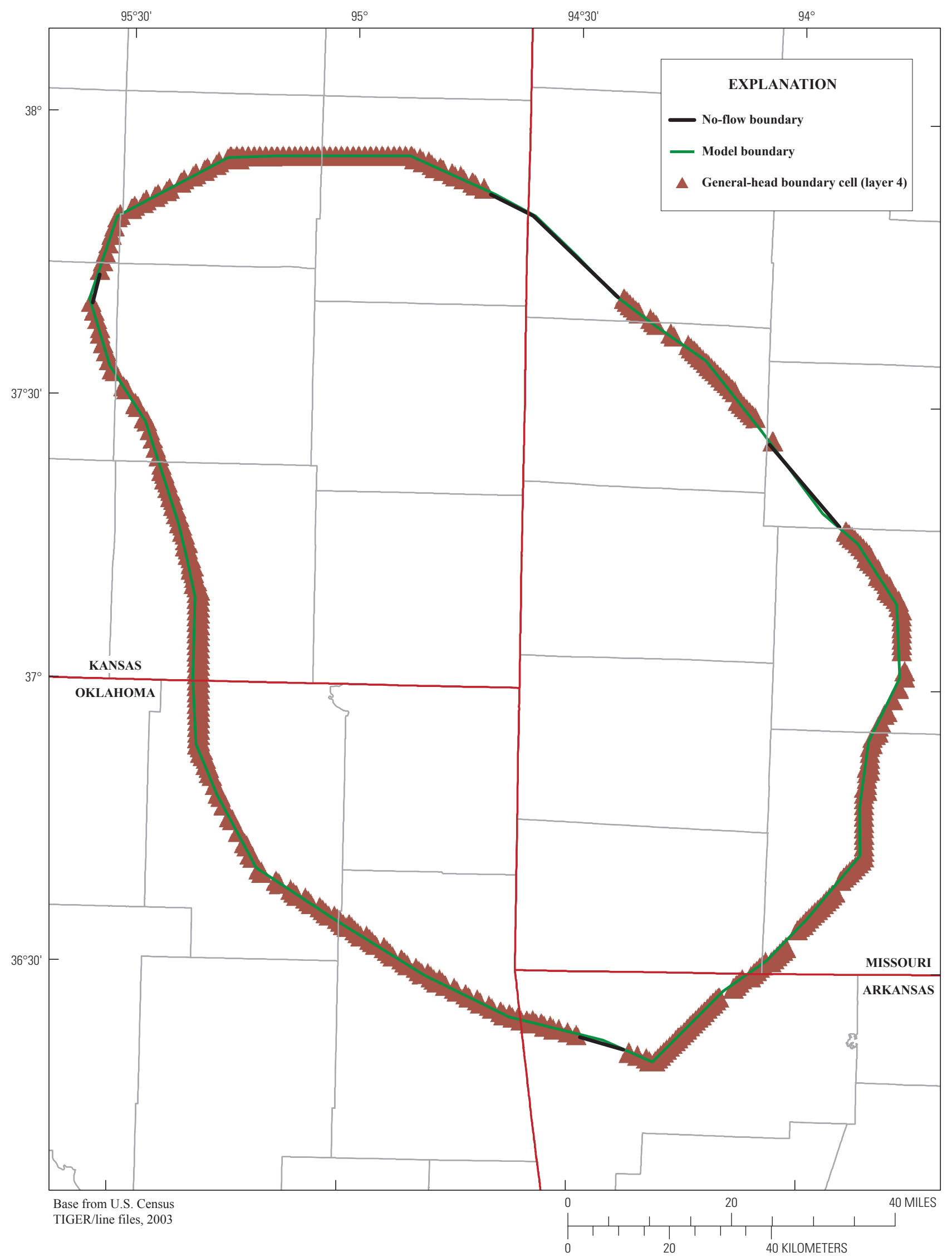

Figure 10. General-head boundary conditions, layer 4 (Ozark aquifer). 


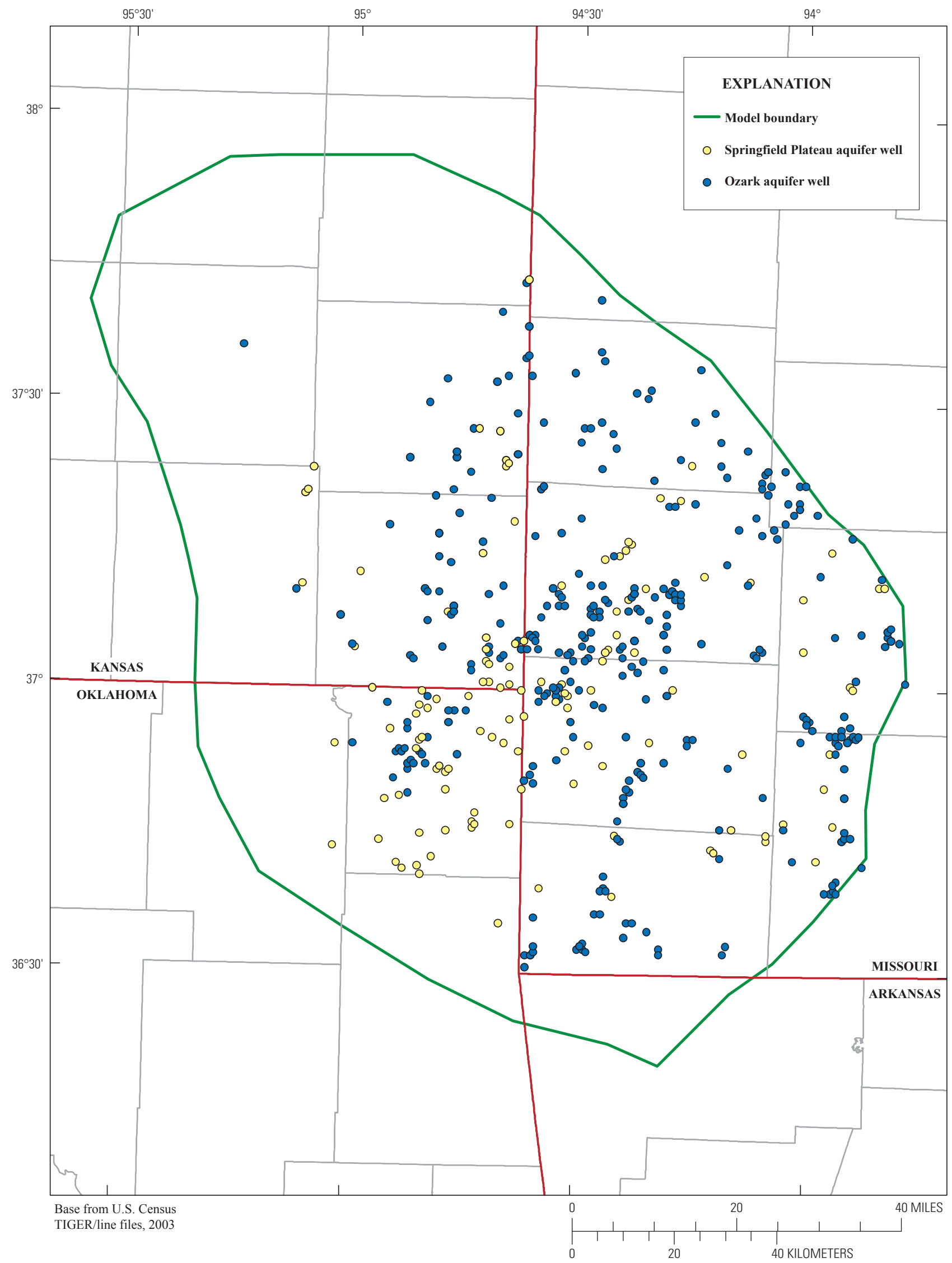

Figure 11. Pumping wells specified in the model area. 


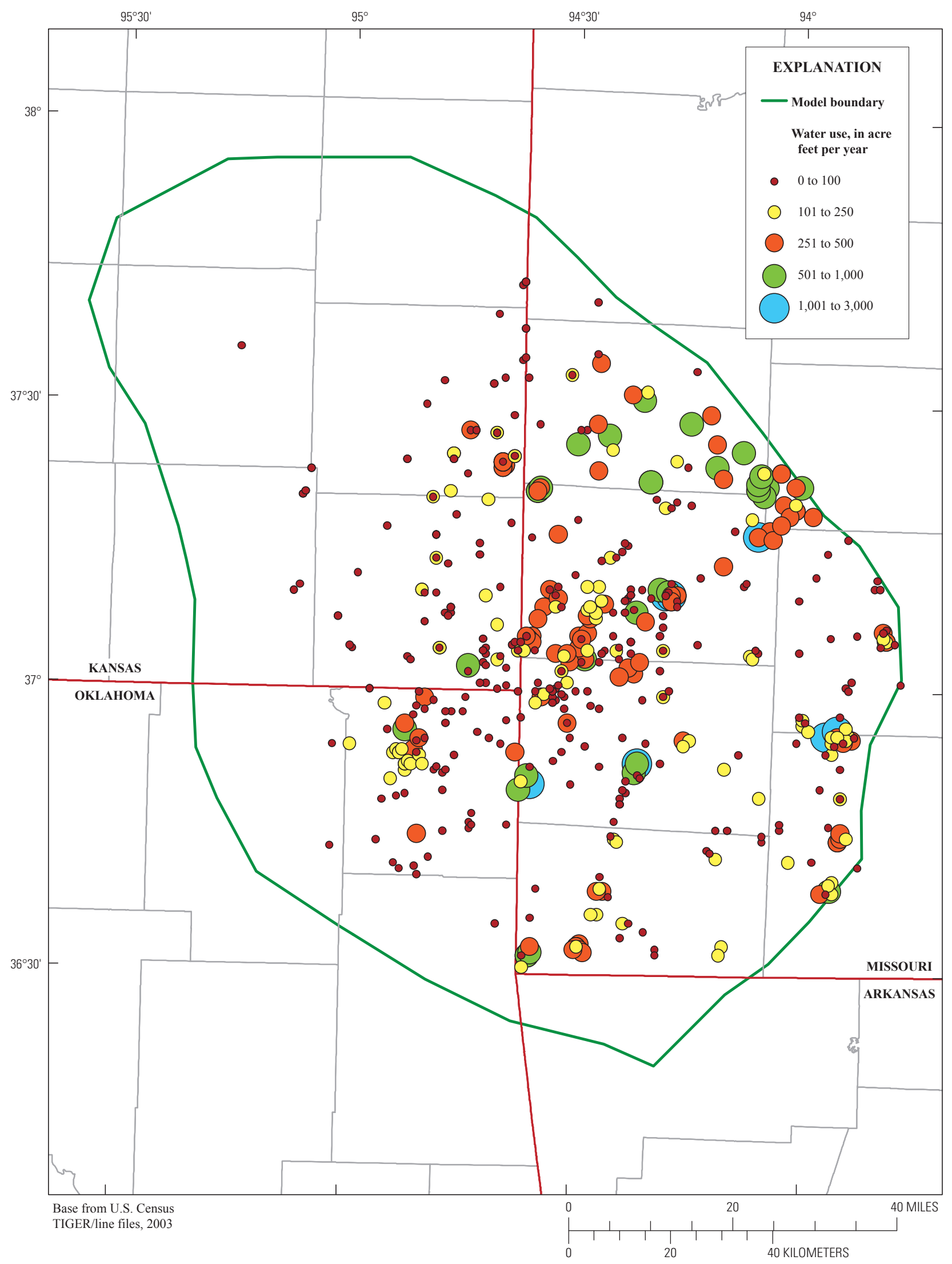

Figure 12. Water use (Springfield Plateau and Ozark aquifers combined) in 2006. 
Table 6. Hydrologic property values specified in the calibrated model.

[WIPCU, Western Interior Plains confining unit; SPA, Springfield Plateau aquifer; OZCU, Ozark confining unit; OA, Ozark aquifer. Values with more than one significant figure were obtained using automated parameter estimation]

\begin{tabular}{|c|c|c|c|c|c|c|}
\hline \multirow{2}{*}{$\begin{array}{c}\text { Zone Name } \\
\text { (as shown } \\
\text { on figures } \\
\text { 13A-D) }\end{array}$} & \multirow{2}{*}{ Layer } & \multirow{2}{*}{$\begin{array}{l}\text { Hydro- } \\
\text { geologic } \\
\text { unit }\end{array}$} & \multicolumn{2}{|c|}{ Hydraulic conductivity, feet per day } & \multirow{2}{*}{$\begin{array}{c}\text { Specific storage, } \\
1 / \text { foot }\end{array}$} & \multirow{2}{*}{$\begin{array}{l}\text { Specific yield, } \\
\text { dimensionless }\end{array}$} \\
\hline & & & Horizontal & Vertical & & \\
\hline $\mathrm{p} 1$ & 1 & WIPCU & $2.0000 \mathrm{E}+00$ & $1.0000 \mathrm{E}-05$ & $1.0000 \mathrm{E}-05$ & 0.2 \\
\hline p2 & 1 & WIPCU & $1.0000 \mathrm{E}+00$ & $1.0000 \mathrm{E}-02$ & $1.0000 \mathrm{E}-05$ & 0.2 \\
\hline p3 & 1 & WIPCU & $1.0000 \mathrm{E}+00$ & $1.0000 \mathrm{E}-01$ & $1.0000 \mathrm{E}-05$ & 0.2 \\
\hline sp1 & 2 & SPA & $2.3650 \mathrm{E}+01$ & $1.0000 \mathrm{E}-01$ & $5.0000 \mathrm{E}-05$ & 0.01 \\
\hline spla & 2 & SPA & $2.3650 \mathrm{E}+01$ & $1.0000 \mathrm{E}-01$ & $5.0000 \mathrm{E}-05$ & 0.1 \\
\hline $\mathrm{sp} 2$ & 2 & SPA & $2.0000 \mathrm{E}+00$ & $1.0000 \mathrm{E}-01$ & $1.0000 \mathrm{E}-05$ & 0.1 \\
\hline sp3 & 2 & SPA & $8.9396 \mathrm{E}-01$ & $2.9700 \mathrm{E}-04$ & $1.0000 \mathrm{E}-05$ & 0.1 \\
\hline sp4 & 2 & SPA & $1.5000 \mathrm{E}+01$ & $3.0000 \mathrm{E}-01$ & $5.0000 \mathrm{E}-06$ & 0.2 \\
\hline sp5 & 2 & SPA & $4.6000 \mathrm{E}+00$ & $1.0000 \mathrm{E}-01$ & $1.0000 \mathrm{E}-05$ & 0.1 \\
\hline $\mathrm{sp} 5 \mathrm{~b}$ & 2 & SPA & $3.5000 \mathrm{E}+01$ & $1.0000 \mathrm{E}+00$ & $1.0000 \mathrm{E}-05$ & 0.1 \\
\hline sp6 & 2 & SPA & $1.5000 \mathrm{E}+01$ & $5.0000 \mathrm{E}-01$ & $1.0000 \mathrm{E}-05$ & 0.1 \\
\hline mines & 2 & Mines & $2.5000 \mathrm{E}+04$ & $1.0000 \mathrm{E}+04$ & $1.0000 \mathrm{E}-05$ & 1.0 \\
\hline ozcul & 3 & OZCU & $1.0000 \mathrm{E}-05$ & $2.0000 \mathrm{E}-06$ & $5.0000 \mathrm{E}-06$ & 0.1 \\
\hline ozcu2 & 3 & $\mathrm{OZCU}$ & $4.0000 \mathrm{E}-05$ & $3.0000 \mathrm{E}-06$ & $5.0000 \mathrm{E}-06$ & 0.1 \\
\hline ozcu2a & 3 & $\mathrm{OZCU}$ & $4.0000 \mathrm{E}-05$ & $2.4800 \mathrm{E}-06$ & $5.0000 \mathrm{E}-06$ & 0.1 \\
\hline ozcu3 & 3 & $\mathrm{OZCU}$ & $4.0000 \mathrm{E}-05$ & $4.0000 \mathrm{E}-06$ & $5.0000 \mathrm{E}-06$ & 0.1 \\
\hline ozcu4 & 3 & OZCU & $4.0000 \mathrm{E}-05$ & $4.0000 \mathrm{E}-07$ & $5.0000 \mathrm{E}-06$ & 0.1 \\
\hline ozcu5b & 3 & OZCU & $4.0000 \mathrm{E}-05$ & $1.7200 \mathrm{E}-05$ & $5.0000 \mathrm{E}-06$ & 0.1 \\
\hline ozcu5a & 3 & OZCU & $4.0000 \mathrm{E}-05$ & $1.9300 \mathrm{E}-06$ & $5.0000 \mathrm{E}-06$ & 0.1 \\
\hline ozccu5 & 3 & $\mathrm{OZCU}$ & $4.0000 \mathrm{E}-05$ & $2.4500 \mathrm{E}-05$ & $5.0000 \mathrm{E}-06$ & 0.1 \\
\hline ozcu6 & 3 & $\mathrm{OZCU}$ & $1.0000 \mathrm{E}-05$ & $2.0000 \mathrm{E}-07$ & $5.0000 \mathrm{E}-06$ & 0.1 \\
\hline ozcu7 & 3 & OZCU & $4.0000 \mathrm{E}-05$ & $4.0000 \mathrm{E}-06$ & $5.0000 \mathrm{E}-06$ & 0.1 \\
\hline oz1 & 4 & $\mathrm{OA}$ & $1.8083 \mathrm{E}+00$ & $1.8083 \mathrm{E}+00$ & $1.2200 \mathrm{E}-05$ & 0.014591 \\
\hline oz2 & 4 & $\mathrm{OA}$ & $4.0035 \mathrm{E}-01$ & $4.0035 \mathrm{E}-01$ & $1.2400 \mathrm{E}-05$ & 0.014591 \\
\hline oz3 & 4 & $\mathrm{OA}$ & $5.0000 \mathrm{E}+00$ & $5.0000 \mathrm{E}-01$ & $1.9200 \mathrm{E}-07$ & 0.014591 \\
\hline oz4d & 4 & $\mathrm{OA}$ & $1.5197 \mathrm{E}+00$ & $1.0000 \mathrm{E}-01$ & $2.6200 \mathrm{E}-05$ & 0.02 \\
\hline oz4c & 4 & $\mathrm{OA}$ & $1.0145 \mathrm{E}-01$ & $1.0000 \mathrm{E}-02$ & $4.0000 \mathrm{E}-06$ & 0.01 \\
\hline oz $4 b$ & 4 & $\mathrm{OA}$ & $2.3456 \mathrm{E}+00$ & 3.7003E-01 & $2.2000 \mathrm{E}-06$ & 0.014591 \\
\hline oz4a & 4 & $\mathrm{OA}$ & $3.7003 \mathrm{E}-01$ & $3.7003 \mathrm{E}-01$ & $2.2000 \mathrm{E}-06$ & 0.014591 \\
\hline oz4 & 4 & $\mathrm{OA}$ & $3.4826 \mathrm{E}-01$ & $1.0000 \mathrm{E}-01$ & $1.0000 \mathrm{E}-07$ & 0.014591 \\
\hline $0 z 5 \mathrm{a}$ & 4 & $\mathrm{OA}$ & $6.1192 \mathrm{E}-01$ & $1.0000 \mathrm{E}-01$ & $1.4900 \mathrm{E}-06$ & 0.014591 \\
\hline oz5 & 4 & $\mathrm{OA}$ & $5.1559 \mathrm{E}-01$ & 4.9230E-01 & $2.4500 \mathrm{E}-07$ & 0.000356 \\
\hline oz6 & 4 & $\mathrm{OA}$ & $1.0538 \mathrm{E}-01$ & $1.0000 \mathrm{E}-01$ & $3.9700 \mathrm{E}-05$ & 0.074995 \\
\hline oz7 & 4 & $\mathrm{OA}$ & $2.5777 \mathrm{E}-01$ & $1.0000 \mathrm{E}-01$ & $2.6200 \mathrm{E}-05$ & 0.02 \\
\hline oz8 & 4 & $\mathrm{OA}$ & $9.8124 \mathrm{E}-01$ & $9.8124 \mathrm{E}-01$ & $1.1400 \mathrm{E}-05$ & 0.014591 \\
\hline oz9 & 4 & $\mathrm{OA}$ & $1.5897 \mathrm{E}+00$ & $1.4000 \mathrm{E}-01$ & $3.1800 \mathrm{E}-06$ & 0.014591 \\
\hline oz10 & 4 & $\mathrm{OA}$ & $1.0702 \mathrm{E}-01$ & $5.0000 \mathrm{E}-03$ & $2.2300 \mathrm{E}-07$ & 0.000356 \\
\hline
\end{tabular}



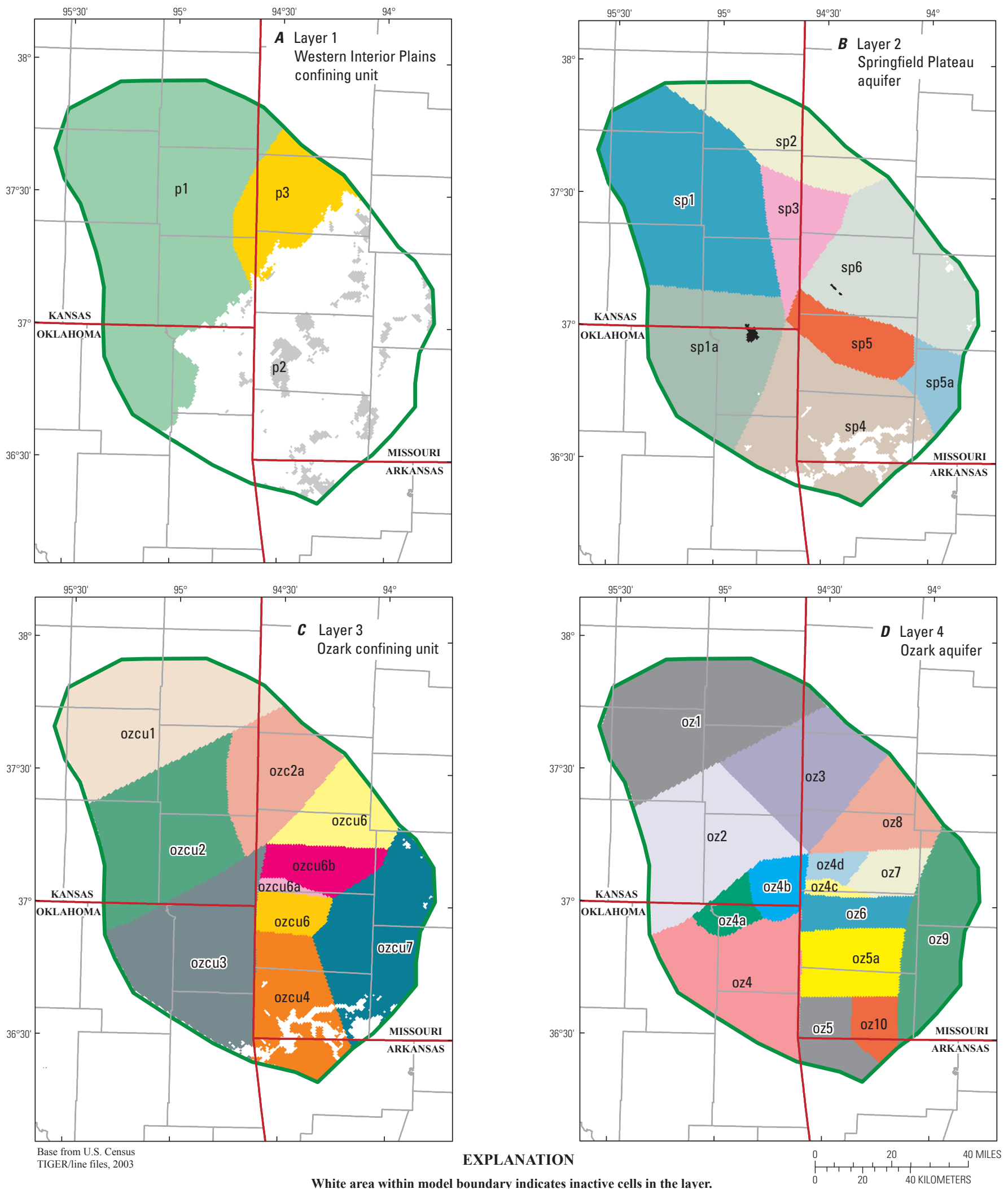

White area within model boundary indicates inactive cells in the layer. Color represents continuity of individual hydrologic-property zones.

Values of hydrologic properties are listed in table 6

Figure 13. Hydrologic property zones for (A) layer 1 (Western Interior Plains confining unit), (B) layer 2 (Springfield Plateau aquifer), (C) layer 3 (Ozark confining unit), and (D) layer 4 (Ozark aquifer). White areas within the model boundary represent active cells in the layer. Colors are used to designate the continuity of individual hydrologic-property zones. Values of hydrologic properties are listed in table 6. 
Anisotropy (the ratio of vertical to horizontal hydraulic conductivity) is poorly defined but is an important variable for characterizing flow within the model area, particularly flow between and through layers. Individual layers represent formations comprised of alternating layers of shale and more permeable carbonate rock, resulting in an anisotropy value that may be quite small (less than 0.0001). Horizontal flow is likely to predominate over vertical flow resulting from vertical contrasts in permeability and flow along bedding planes caused by dissolution along horizontal fractures (Edwin P. Weeks, U.S. Geological Survey, written commun., 2008).

The specific storage of a saturated confined aquifer is the volume of water that an aquifer releases from storage per unit decline in hydraulic head (Freeze and Cherry, 1979, p. 58). The release of water occurs from the compressibility of the aquifer (which for carbonate aquifers is very small) and the compressibility of water. Specific storage estimates may be obtained by dividing the value of storage coefficient (determined from aquifer testing) by the aquifer thickness (Lohman, 1979, p. 53). Hart and Wang (1995) provide measurements of various bulk moduli for a porous limestone that can be used to estimate a value of specific storage for the limestone. Application of their method yields an estimate for specific storage of $2 \times 10^{-8} / \mathrm{ft}$ (Edwin P. Weeks, U.S. Geological Survey, written commun., 2008) that could be considered a minimum value. This value is consistent with other suggested values for sedimentary rocks (Lohman, 1979, p. 53).

Specific yield is the volume of water that an unconfined aquifer releases from storage per unit surface area of aquifer per unit decline in the water table resulting from gravity drainage (Freeze and Cherry, 1979, p. 61). Specific yield values used in the model vary considerably (table 6), ranging from 0.000356 to 0.2 for all units other than the mine zone, which was set to a value of 1.0. For carbonate aquifers, specific yield may be considered the fracture porosity minus the specific retention. Few test values of specific yield for carbonate rocks are available in the literature. Hydraulic tests on carbonate rocks in Poland and Spain provide some reference values for specific yield and other properties (Motyka and others, 1998; Pulido-Bosch and others, 2004). Mean specific-yield values for limestone and dolomite in Poland were 0.00006 and 0.0013 , respectively; mean specific-yield values for both limestone and dolomite in Spain were 0.00579.

A comparison of hydrologic properties specified in the current model (table 6) may be made with values from previous models and field investigations for the model area and vicinity (table 2). A comparison of hydrologic properties for layer 1 for the Western Interior Plains confining unit is limited to the vertical hydraulic conductivity $\left(1 \times 10^{-1}\right.$ to $1 \times 10^{-5} \mathrm{ft} / \mathrm{d}$ for the current model), which covers a broader range than the values used in the Imes and Emmett (1994) regional model of 0.002 to $0.009 \mathrm{ft} / \mathrm{d}$.

The horizontal hydraulic-conductivity values used for layer 2 for the Springfield Plateau aquifer are about $9 \times 10^{-1}$ to $2.37 \times 10^{1} \mathrm{ft} / \mathrm{d}$, and fit within the range of values used in other models. For the Springfield Plateau aquifer, Imes (1989) used values of 4.3 to $43 \mathrm{ft} / \mathrm{d}$ in the Springfield, Missouri area model, Imes and Emmett (1994) used a value of $21.6 \mathrm{ft} / \mathrm{d}$ for the part of their regional model that overlaps the model area, and Reed and Czarnecki (2006) used values of 10 to $35 \mathrm{ft} / \mathrm{d}$ in their model.

A comparison of hydraulic property values for the Ozark confining unit is limited to vertical hydraulic conductivity values. In the current model, these values range from $2 \times 10^{-7}$ to $1.72 \times 10^{-5} \mathrm{ft} / \mathrm{d}$, which are considerably smaller than values used in the model of Imes and Emmett (1994) in which values ranging from 0.0009 to $0.0043 \mathrm{ft} / \mathrm{d}$ were specified.

The hydraulic-conductivity values used for layer 4 for the Ozark aquifer $(0.1$ to $5 \mathrm{ft} / \mathrm{d})$ are about a factor of 6 less than the value of about $30 \mathrm{ft} / \mathrm{d}$ obtained from Macfarlane (2007) and are within the lower part of the range of values reported by Freeze and Cherry (1979) for karstic limestone (0.1 to $2,000 \mathrm{ft} / \mathrm{d}$ ). They are similar to and larger than the hydraulicconductivity values report by Pugh (2008) in Arkansas ( 0.44 to $1.49 \mathrm{ft} / \mathrm{d}$ ). Values of specific storage used in the model for the Ozark aquifer range from about $1 \times 10^{-7}$ to $4 \times 10^{-5} 1$ day, which are similar and larger than values derived from the hydraulic tests of Macfarlane (2007) (1.6 $\times 10-7$ to $1.9 \times 10^{-7} 1 /$ day).

\section{Water-Level Observations}

Water-level observation data were obtained from wells identified within the model area using historical data contained in the USGS National Water Information System (NWIS) and from State water agencies (http://www.dnr.mo.gov/env/ wre/groundwater/obswell/obswell-swro.htm; http://www.kgs. ku.edu/Magellan/WaterLevels/index.html).

Water-level data contained in NWIS represent measurements made at different frequencies at individual wells, which might range from one to multiple measurements made per well within a 10-year period. Multiple measurements were contained in the NWIS database for the period 1980 to 1989. To utilize water-level data for that period, average water-level altitudes were calculated if multiple water levels were measured per well during 1980 to 1989 (http://waterdata.usgs.gov/ nwis). Only water-level measurements from the Ozark aquifer were considered for 1980 to 1989 because of the sparseness of available data for the Springfield Plateau aquifer. The spatial coverage of available water-level measurements was highly variable with the best areal coverage for the Springfield Plateau and Ozark aquifers available in 2006 as a result of the water-level reconnaissance made as part of the study of Gillip and others (2008). The potentiometric-surface maps produced by Gillip and others (2008) were constructed using a small number of water-level measurements. Some cones of depression that appear in the model simulated surfaces occur at places where no water-level altitude data were available and knowledge of pumping wells was obtained after that report was completed.

Model fit between simulated and observed water-level altitudes (figs. 14-22) is affected by varying model-parameter 
values (table 6). A map showing the difference between simulated and observed water-level altitudes in the Ozark aquifer using average values derived from measurements made from 1980 to 1989 is shown in figure 14. The magnitude of the difference at each measurement location is shown by the size of each triangular point. The largest discrepancy between simulated and observed water-level altitudes occurs near the cone of depression at Miami, Oklahoma, in Ottawa County (fig. 14). This discrepancy likely occurs because actual water use in that area began in the early 1900s, whereas model specified pumping in that area began in 1959. In addition, accurate simulation of water-level altitudes is more difficult in areas with large hydraulic gradients, such as cones of depression, because of the error associated with specifying the horizontal position of an observation well or a pumping well, which can translate into large differences in simulated water-level altitude over small horizontal distances. The mean absolute error for simulated and observed water-level altitudes for the Ozark aquifer for averaged measurements for 1980 to 1989 is 67.8 $\mathrm{ft}$ compared to a range in observed water-level altitude values of $463.8 \mathrm{ft}$; the correlation coefficient $\left(\mathrm{R}^{2}\right)$ (a measure of the fit between simulated and observed water-level values, with a perfect fit equal to 1.0) for these data is 0.786 (fig. 15). A histogram of the differences between simulated and observed water-level altitudes is shown in figure 16, with the largest grouping of differences (14) occurring between $+/-10 \mathrm{ft}$.

Spatial distribution of simulated 2006 water-level altitudes and residuals within the Ozark aquifer are shown in figure 17. Large discrepancies between simulated and observed water-level altitudes occur in large-gradient areas, particularly around cones of depression. A comparison of simulated to observed water-level altitudes (fig. 18) for these 119 points produces a mean absolute error of $56.5 \mathrm{ft}$ and a standard error of $80.98 \mathrm{ft}$ for the data set, which has a range in observed values of $442 \mathrm{ft}$. The histogram for these points (fig. 19) shows these residuals to be more evenly distributed about zero than those for the 1980 to 1989 period. Differences between observed and simulated water-level altitudes approach a normal distribution with more differences ranging from -10 to $10 \mathrm{ft}$ than for any other 20 -foot difference range. This improvement likely results from more accurate water-use data reported for this time period, more spatially distributed water-level altitude data, and more comprehensive information on well completion.

Spatial distribution of simulated 2006 water-level altitudes and residuals within the Springfield Plateau aquifer is shown in figure 20. Mean absolute error for this data set is $41.0 \mathrm{ft}$ (fig. 21), with a correlation coefficient of 0.927 . The range in observed water-level altitudes is $845.2 \mathrm{ft}$. One reason for the good fit associated with this data set is the proximity and effect that simulated rivers have on controlling simulated water-level altitudes within the Springfield Plateau aquifer. A histogram of the difference between simulated and observed water-level altitudes for the Springfield Plateau aquifer is shown in figure 22. Because values on the histogram tend to be more positive than negative, this indicates that the simulated water-level altitudes tend to be lower than observed.

\section{Streamflow Observations}

Streamflow observation data used to determine base flow from groundwater were selected from many measurements available for rivers in the model area. Table 4 contains estimates of observed groundwater flow at five river reaches contained within the Neosho River, Spring River, and Shoal Creek Basins using the difference between observed streamflow from gaging stations at upstream and downstream locations on the specific river reach. Streamflow values that were exceeded 90 percent of the time for the period of record were used in estimating the component of groundwater base flow to the river reach. Simulated discharge is a function of the hydraulic-head gradient between the specified river stage (which varies along a river reach) and the simulated water-level in the adjacent model cells on each side of the river cell. Flow to and from river cells is also a function of the riverbed conductance and the horizontal hydraulic conductivity of the adjacent nonriver cells.

Relative percent difference between observed and simulated streamflow ranged from 13 to 76 percent (table 4). Reasons for the difference may include: (1) assignment of a uniform value of observed discharge to a temporally changing system, (2) error in specification of river stage, (3) error in estimated riverbed conductance value, (4) error in horizontal hydraulic conductivity, and (5) error in specified areally distributed recharge. Given the number of different potential sources of error, matching flows within a factor of 2 for a specific reach was considered acceptable. Taken as a whole, total observed discharge from rivers was 5,291,136 ft $3 / \mathrm{d}$, compared to total simulated discharge of $4,219,651 \mathrm{ft}^{3} / \mathrm{d}$, or a relative percent difference of 23 percent.

\section{Springflow Observations}

Springflow observation data were obtained from Vineyard and Feder (1982) for springs located within the model area. Not all springs occurring in the model area were simulated. Initially the drain package in MODFLOW was used to specify spring discharge. Issues arose with knowing what conductance value to specify at the drain, or how to specify the observed springflow as an observation for parameter estimation using the drain package. Some springs could not be included in the model because the gradient relative to the spring location caused a reverse in flow direction. Because of these conditions, springs are represented using constant-head boundary points. Only discharging springs are represented in the model. Preference for observed spring-flow values was given to larger springs (those with discharge in excess of $100,000 \mathrm{ft}^{3} / \mathrm{d}$ ). The difference between observed and simulated spring discharge is listed in table 5. Error between observed and simulated spring discharge may be related to: (1) use of 


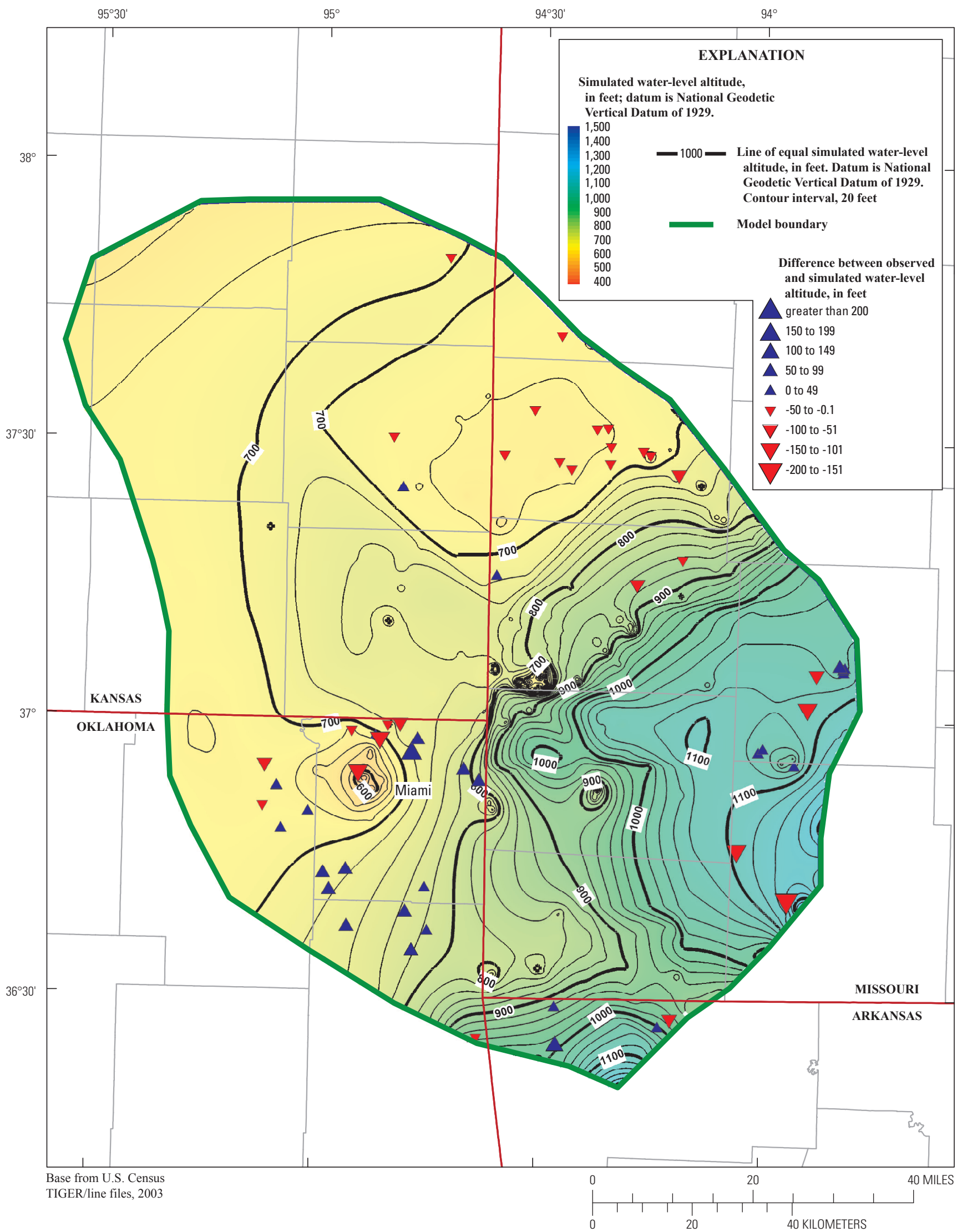

Figure 14. Simulated water-level altitudes in Ozark aquifer and differences between observed and simulated water-level altitude, 1985. 


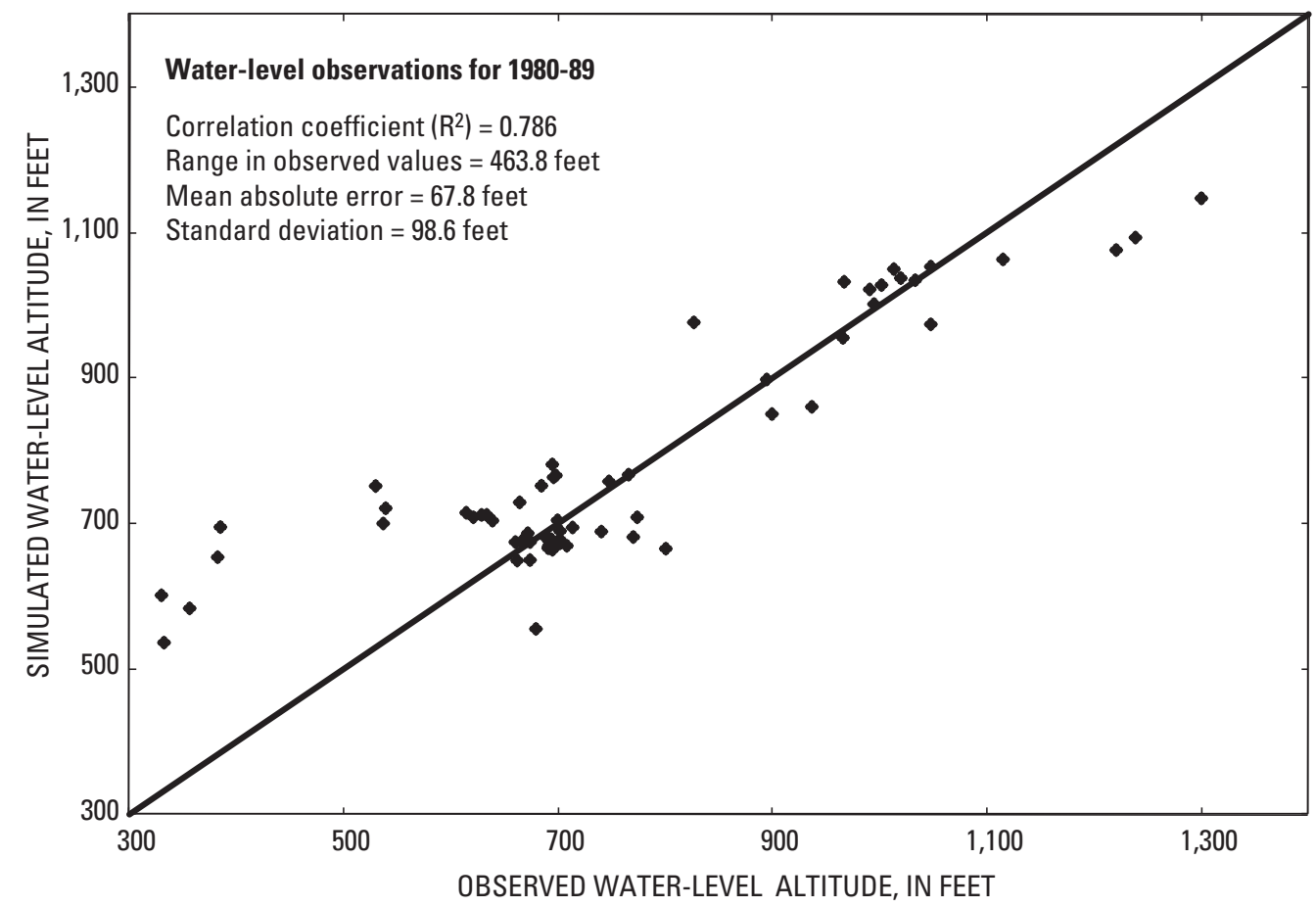

Figure 15. Relation between simulated water-level altitudes and observed water-level altitudes for measurements made between 1980 to 1989 for the Ozark aquifer.

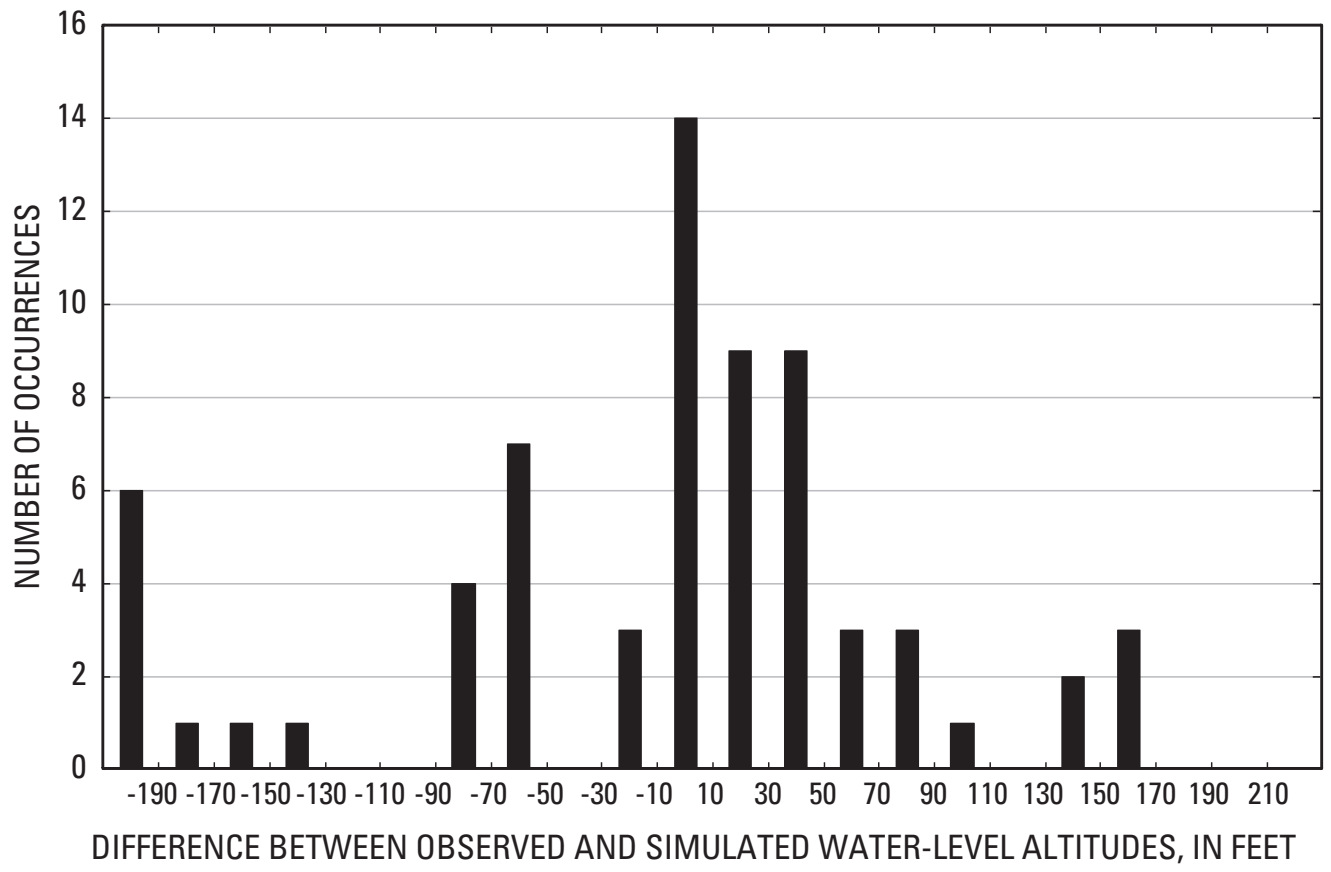

Figure 16. Difference between observed and simulated water-level altitudes for the period 1980 to 1989 for the Ozark aquifer. 


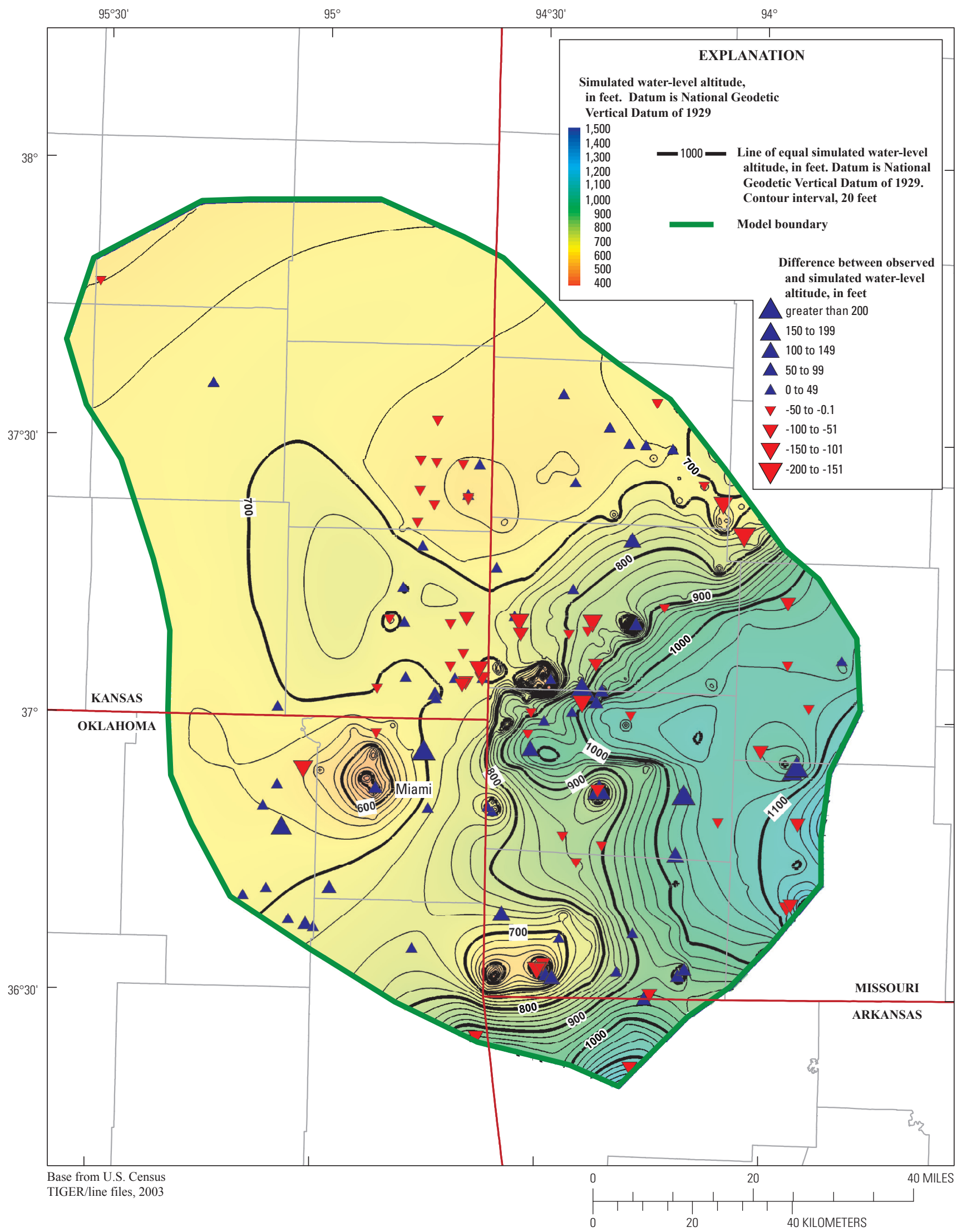

Figure 17. Simulated water-level altitudes in Ozark aquifer and difference between observed and simulated water-level altitude in 2006. 


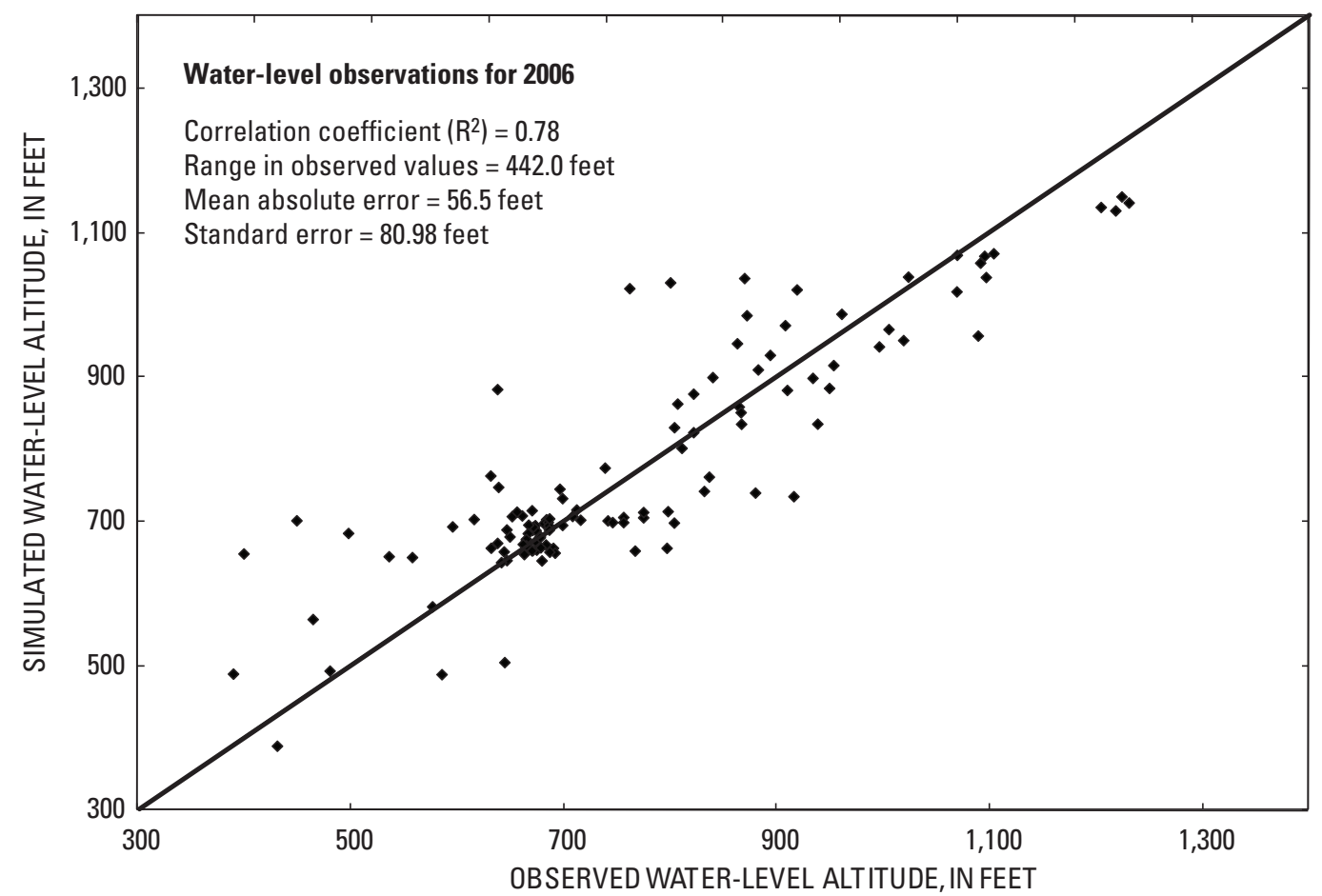

Figure 18. Relation between simulated water-level altitudes and observed water-level altitudes for measurements made for 2006 for the Ozark aquifer.

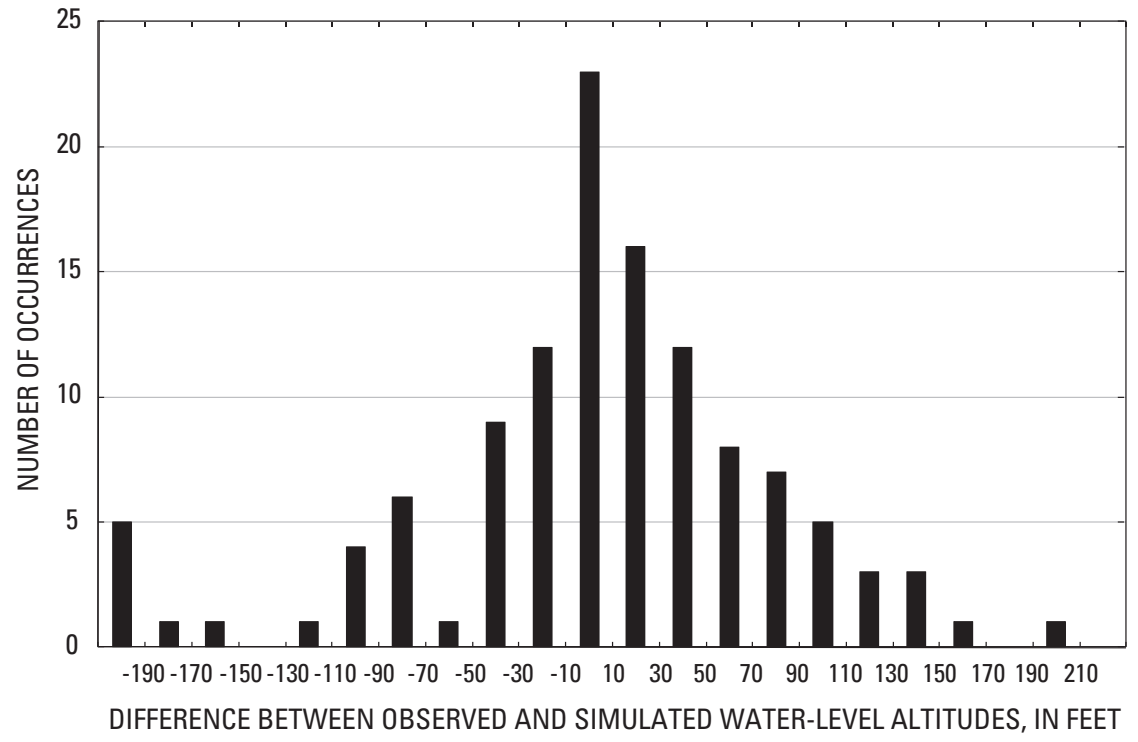

Figure 19. Difference between observed and simulated water-level altitudes for 2006 for the Ozark aquifer. 


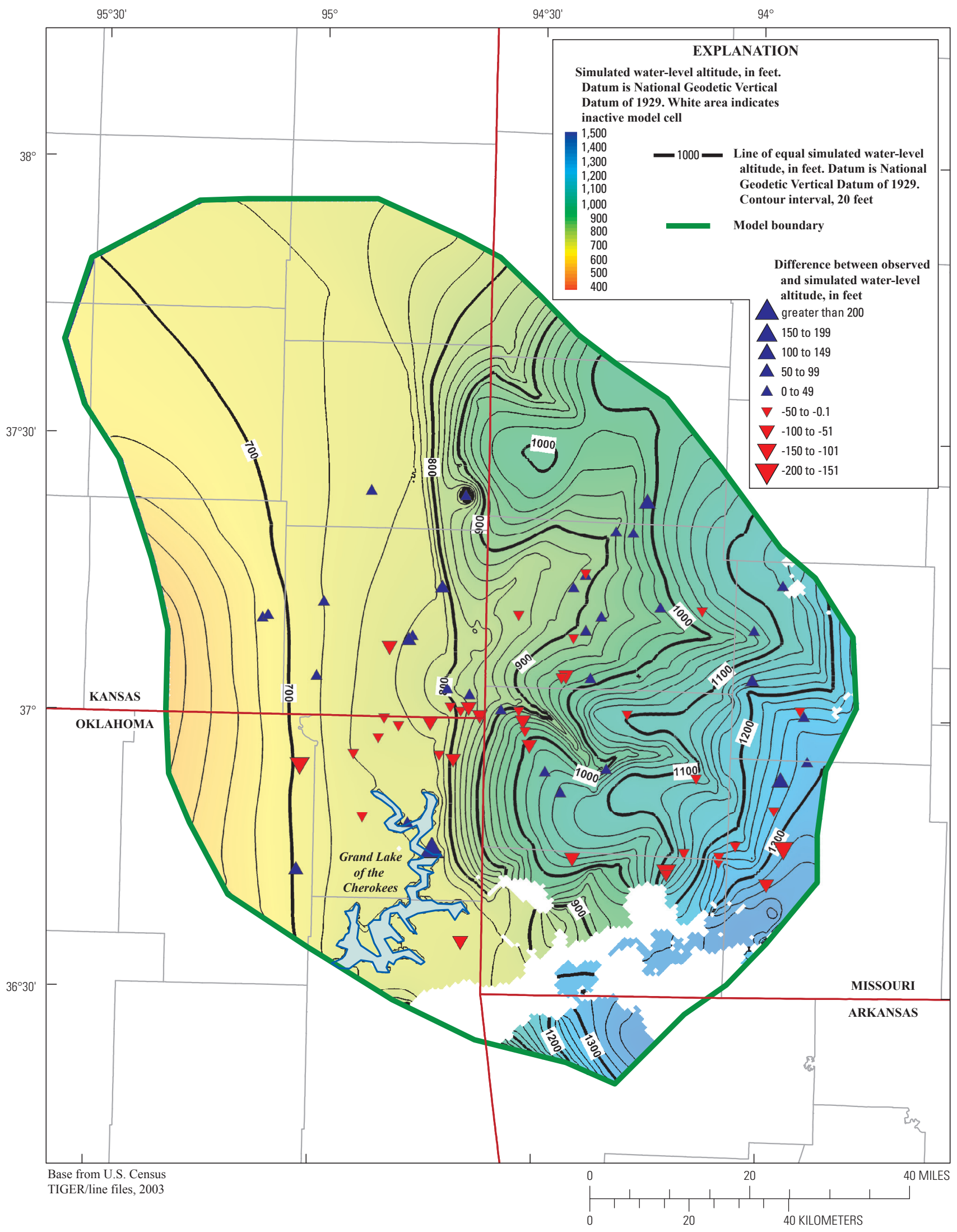

Figure 20. Simulated water-level altitudes in Springfield Plateau aquifer and difference between observed and simulated water-level altitude in 2006. 


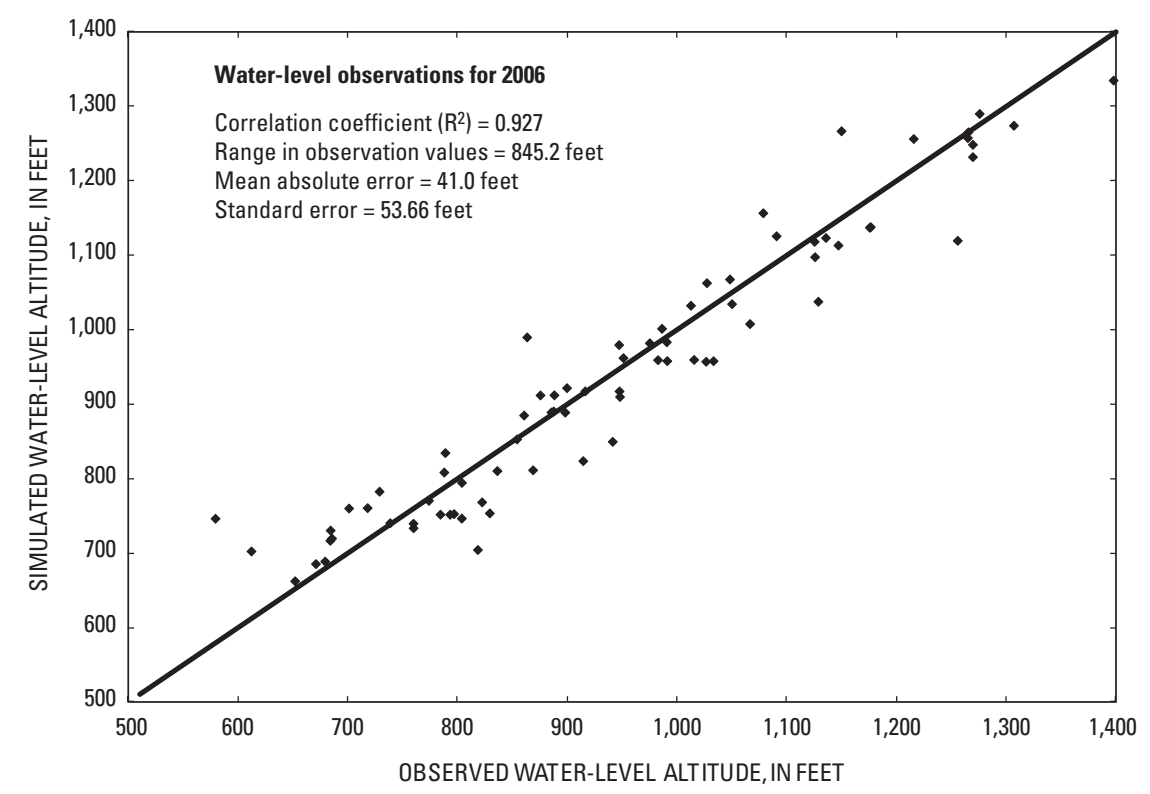

Figure 21. Relation between simulated water-level altitudes and observed water-level altitudes for measurements made for 2006 for the Springfield Plateau aquifer.

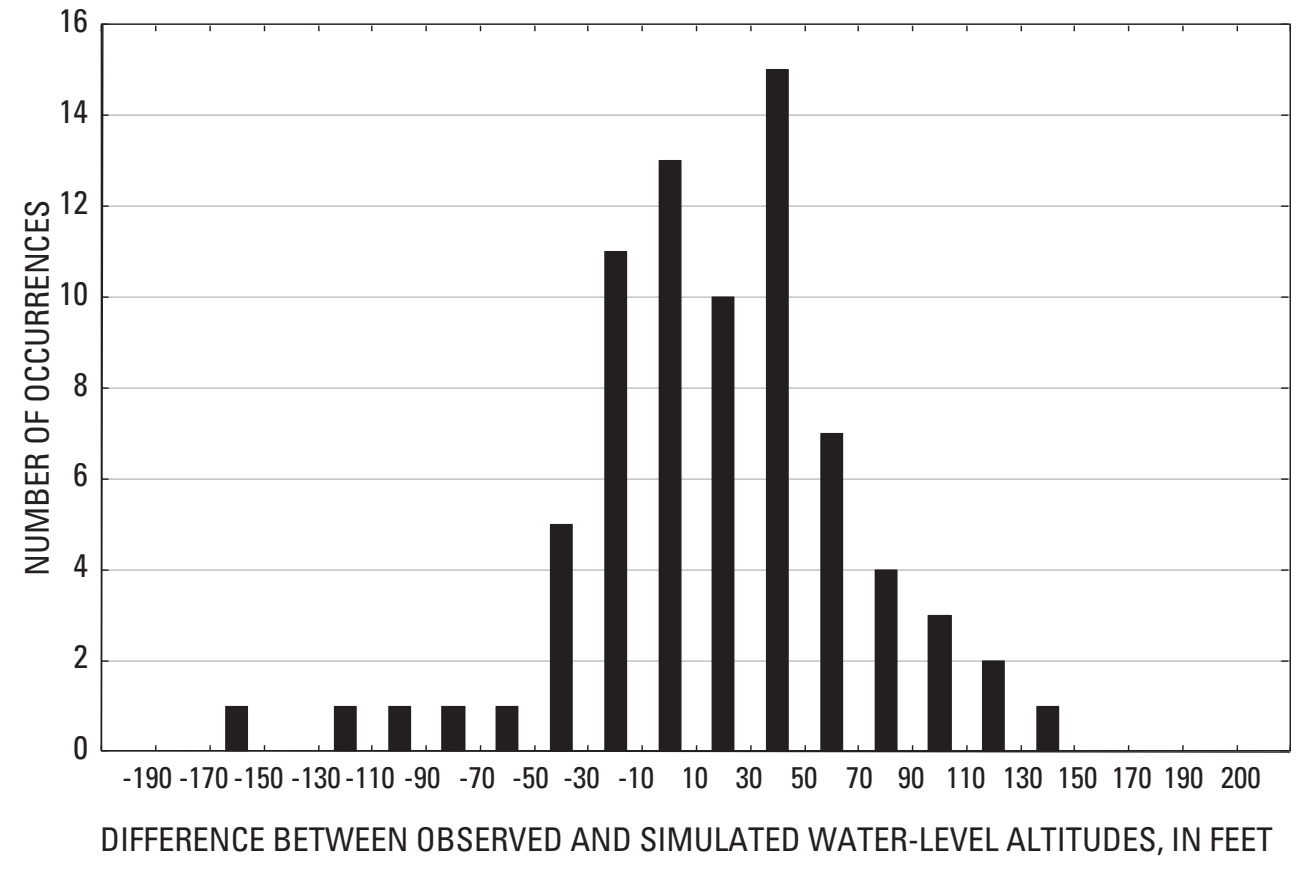

Figure 22. Difference between observed and simulated water-level altitudes for 2006 for the Springfield Plateau aquifer. 
too coarse a finite-difference grid to adequately specify the location of the spring using the constant-head cell (discharge from the spring is averaged over the entire cell area); (2) error in horizontal and vertical hydraulic conductivity; and (3) proximity to other boundary conditions, such as rivers. In many cases, springs within the model area discharge out of steep hillsides adjacent to rivers, resulting in a geometry that was intractable given the coarseness of the model grid $\left(0.25 \mathrm{mi}^{2} /\right.$ cell), and the coarseness of land-surface elevation data (98.4-ft spacing). An example of the effect that proximity to a river has on matching springflow is seen at Clarkson Spring (sites, fig. 9, location T27N R28W 17DDA1), at which simulated spring flow was much less than the observed value, likely because flow that would have gone to the spring is shunted off by an adjacent stream. Taken as a whole, total observed discharge from springs used in the model was $3,637,440 \mathrm{ft}^{3} / \mathrm{d}$, compared to total simulated discharge of $1,200,128 \mathrm{ft}^{3} / \mathrm{d}$, or a relative percent difference of 101 percent (table 5).

\section{Sensitivity Analysis}

Sensitivity analysis of model parameters was performed to determine the effect that changes in the final model parameter values had on the differences between simulated and observed water-level altitude and streamflow using the parameter estimation program PEST (Doherty, 1994). PEST records the "composite sensitivity" of each parameter (that is, the magnitude of the column of the Jacobian matrix pertaining to that parameter multiplied by the weight attached to each observation divided by the number of observations).

Horizontal and vertical hydraulic conductivity, specific storage, and specific yield from model zones within the two layers containing the Ozark confining unit and Ozark aquifer, recharge, and general-head boundary conductances were selected as parameters for the sensitivity analyses. Experience gained during the calibration of the model indicated that parameters within these two layers had the largest effect on simulated water levels within the Ozark aquifer. Composite sensitivity values for each parameter ranked in descending order are listed in table 7 . The six most sensitive parameters from table 7 are vertical hydraulic-conductivity parameters specified within six zones of the Ozark confining unit (ozcu6, ozcu4, ozcu2a, ozcu2, ozcu5a, and ozcu3 shown in figure 13C). The top 14 ranked parameters with the largest composite sensitivity values all occur within the Ozark confining unit, which emphasizes the importance of this unit in affecting simulated water-level altitudes within the Ozark aquifer as well as within the Springfield Plateau aquifer. The least sensitive parameters (those that had minimal effect on simulated water-level altitudes) were general-head conductances in layers 4 and 2, followed by vertical and horizontal hydraulic conductivity in various zones within the Ozark aquifer.

Sensitivity analysis was not performed on values of water use specified in the model using PEST, the assumption being that the values of water use were better known than the parameters specified in the sensitivity analyses. Furthermore, the number of parameters that could be analyzed was limited to 99 parameters in the version of PEST (within GMS) available for use in this study. Hydraulic properties of zones in layers 1 or 2 or streambed conductances were not included as parameters because of the 99-parameter limit and most pumping and stresses on the groundwater system occur in the Ozark aquifer.

\section{Predevelopment Water-Level Altitudes}

To simulate predevelopment conditions (prior to 1959), steady-state conditions were specified for the first stress period using the boundary conditions discussed previously, but with no groundwater pumping specified within the Ozark aquifer. By running the model in this way, the model comes into equilibrium with the boundary conditions; that is, the amount of water entering the model equals the amount of water leaving the model with no change in groundwater storage. Predevelopment water-level altitudes for the Springfield Plateau aquifer (layer 2) are shown in figure 23. Groundwater flow east of the Missouri-Kansas State line is predominantly toward rivers that drain the Springfield Plateau aquifer; west of the state line, groundwater flow is toward the western boundary of the model where a general-head boundary is specified. The simulated water-level altitude distribution and flow pattern within the Springfield Plateau aquifer are consistent with that developed for predevelopment conditions by Imes and Emmett (1994, p. 68). The simulated large hydraulic gradients in the eastern half of the Springfield Plateau aquifer result where land surface and rivers intersect, and areally distributed recharge is applied directly to the aquifer. The aquifer dips below the Western Interior Plains confining unit in the western half of the model (fig. 5), eliminating the direct effects of river stage and areally distributed recharge on the simulated water-level altitudes within the Springfield Plateau aquifer.

Simulated flow conditions within the Ozark aquifer differ from those in the Springfield Plateau aquifer. Predevelopment water levels for the Ozark aquifer (layer 4) are shown in figure 24. Groundwater-flow direction is generally towards the northwest and is affected by hydraulic properties specified within the Ozark aquifer and the general-head boundary conditions (fig. 10) specified for that layer. The simulated water-level altitude distribution and flow pattern within the Ozark aquifer are consistent with that developed for predevelopment conditions by Imes and Emmett (1994, p. 50). 
Table 7. Sensitivity of model to changes in parameter values within the Ozark aquifer and Ozark confining unit.

[OZCU, Ozark confining unit; OA, Ozark aquifer; vk, vertical hydraulic conductivity (feet per day); hk, horizontal hydraulic conductivity (feet per day); ss, specific storage (1/feet); rch, recharge (feet per day; zones shown on fig. 7); ghb, general head boundary conductance; --, not applicable]

\begin{tabular}{|c|c|c|c|c|c|}
\hline Rank & Parameter & Unit name & $\begin{array}{c}\text { Zone name } \\
\text { (from } \\
\text { figure 13) }\end{array}$ & $\begin{array}{c}\text { Calibrated } \\
\text { parameter } \\
\text { value } \\
\text { (variable } \\
\text { units) }\end{array}$ & $\begin{array}{c}\text { Composite } \\
\text { sensitivity } \\
\text { value } \\
\text { (dimensionless) }\end{array}$ \\
\hline 1 & vk_34 & OZCU & ozcu6 & $2.00 \mathrm{E}-07$ & $2.53 \mathrm{E}+13$ \\
\hline 2 & vk_30 & OZCU & ozcu4 & $4.00 \mathrm{E}-07$ & $1.27 \mathrm{E}+13$ \\
\hline 3 & vk_28 & OZCU & ozcu $2 a$ & $2.48 \mathrm{E}-06$ & $2.02 \mathrm{E}+12$ \\
\hline 4 & vk_27 & OZCU & ozcu2 & $3.00 \mathrm{E}-06$ & $1.69 \mathrm{E}+12$ \\
\hline 5 & vk_32 & OZCU & ozcu5a & $1.93 \mathrm{E}-06$ & $1.28 \mathrm{E}+12$ \\
\hline 6 & vk_29 & OZCU & ozcu3 & $4.00 \mathrm{E}-06$ & $1.26 \mathrm{E}+12$ \\
\hline 7 & hk_9 & OZCU & ozcu6 & $1.00 \mathrm{E}-05$ & $5.06 \mathrm{E}+11$ \\
\hline 8 & vk_35 & OZCU & ozcu 7 & $4.00 \mathrm{E}-06$ & $3.50 \mathrm{E}+11$ \\
\hline 9 & vk_31 & OZCU & ozcu 5 b & $1.72 \mathrm{E}-05$ & $2.91 \mathrm{E}+11$ \\
\hline 10 & hk_5 & OZCU & ozcu4 & $4.00 \mathrm{E}-05$ & $1.27 \mathrm{E}+11$ \\
\hline 11 & hk_2 & OZCU & ozcu 2 & $4.00 \mathrm{E}-05$ & $1.27 \mathrm{E}+11$ \\
\hline 12 & hk_7 & OZCU & ozcu5a & $4.00 \mathrm{E}-05$ & $1.27 \mathrm{E}+11$ \\
\hline 13 & hk_4 & OZCU & ozcu3 & $4.00 \mathrm{E}-05$ & $1.27 \mathrm{E}+11$ \\
\hline 14 & hk_6 & OZCU & ozcu5b & $4.00 \mathrm{E}-05$ & $1.26 \mathrm{E}+11$ \\
\hline 15 & rch_78 & -- & -- & $1.00 \mathrm{E}-04$ & $5.06 \mathrm{E}+10$ \\
\hline 16 & rch_81 & -- & -- & $1.11 \mathrm{E}-04$ & $4.54 \mathrm{E}+10$ \\
\hline 17 & vk_26 & OZCU & ozcu1 & $2.00 \mathrm{E}-06$ & $3.63 \mathrm{E}+10$ \\
\hline 18 & ss_68 & $\mathrm{OA}$ & oz4 & $1.00 \mathrm{E}-07$ & $1.72 \mathrm{E}+10$ \\
\hline 19 & rch_79 & -- & -- & 4.35E-04 & $1.16 \mathrm{E}+10$ \\
\hline 20 & ss_63 & $\mathrm{OA}$ & oz3 & $1.92 \mathrm{E}-07$ & $8.10 \mathrm{E}+09$ \\
\hline 21 & hk_1 & OZCU & ozcu1 & $1.00 \mathrm{E}-05$ & $7.47 \mathrm{E}+09$ \\
\hline 22 & Ss_75 & $\mathrm{OA}$ & oz10 & $2.23 \mathrm{E}-07$ & $7.27 \mathrm{E}+09$ \\
\hline 23 & rch_82 & -- & -- & $7.68 \mathrm{E}-04$ & $6.59 \mathrm{E}+09$ \\
\hline 24 & rch_76 & -- & -- & $2.00 \mathrm{E}-05$ & $3.80 \mathrm{E}+09$ \\
\hline 25 & hk_10 & OZCU & ozcu 7 & $4.00 \mathrm{E}-05$ & $3.65 \mathrm{E}+09$ \\
\hline 26 & vk_33 & OZCU & ozcu5 & $2.45 \mathrm{E}-05$ & $2.08 \mathrm{E}+09$ \\
\hline 27 & Ss_70 & $\mathrm{OA}$ & oz5a & $2.45 \mathrm{E}-07$ & $2.03 \mathrm{E}+09$ \\
\hline 28 & hk_8 & OZCU & ozcu5 & $4.00 \mathrm{E}-05$ & $2.02 \mathrm{E}+09$ \\
\hline 29 & hk_3 & OZCU & ozcu2a & $4.00 \mathrm{E}-05$ & $1.92 \mathrm{E}+09$ \\
\hline 30 & rch_77 & -- & -- & $1.10 \mathrm{E}-04$ & $1.77 \mathrm{E}+09$ \\
\hline 31 & ss_69 & $\mathrm{OA}$ & oz5a & $1.49 \mathrm{E}-06$ & $1.57 \mathrm{E}+09$ \\
\hline 32 & ss_66 & $\mathrm{OA}$ & oz4b & $2.20 \mathrm{E}-06$ & $1.40 \mathrm{E}+09$ \\
\hline 33 & ss_67 & $\mathrm{OA}$ & oz4a & $2.20 \mathrm{E}-06$ & $1.11 \mathrm{E}+09$ \\
\hline 34 & vk_50 & $\mathrm{OA}$ & oz10 & $5.00 \mathrm{E}-03$ & $1.01 \mathrm{E}+09$ \\
\hline 35 & ss_74 & $\mathrm{OA}$ & oz9 & $3.18 \mathrm{E}-06$ & $9.06 \mathrm{E}+08$ \\
\hline 36 & ss_53 & $\mathrm{OZCU}$ & ozcu2a & $5.00 \mathrm{E}-06$ & $6.51 \mathrm{E}+08$ \\
\hline 37 & ss_58 & OZCU & ozcu 5 & $5.00 \mathrm{E}-06$ & $5.69 \mathrm{E}+08$ \\
\hline
\end{tabular}


Table 7. Sensitivity of model to changes in parameter values within the Ozark aquifer and Ozark confining unit.-Continued

[OZCU, Ozark confining unit; OA, Ozark aquifer; vk, vertical hydraulic conductivity (feet per day); hk, horizontal hydraulic conductivity (feet per day); ss, specific storage (1/feet); rch, recharge (feet per day; zones shown on fig. 7); ghb, general head boundary conductance; --, not applicable]

\begin{tabular}{|c|c|c|c|c|c|}
\hline Rank & Parameter & Unit name & $\begin{array}{l}\text { Zone name } \\
\text { (from } \\
\text { figure 13) }\end{array}$ & $\begin{array}{l}\text { Calibrated } \\
\text { parameter } \\
\text { value } \\
\text { (variable } \\
\text { units) }\end{array}$ & $\begin{array}{c}\text { Composite } \\
\text { sensitivity } \\
\text { value } \\
\text { (dimensionless) }\end{array}$ \\
\hline 38 & ss_65 & $\mathrm{OA}$ & oz4c & $4.00 \mathrm{E}-06$ & $5.46 \mathrm{E}+08$ \\
\hline 39 & ss_51 & OZCU & ozcu1 & $5.00 \mathrm{E}-06$ & $5.29 \mathrm{E}+08$ \\
\hline 40 & vk_40 & $\mathrm{OA}$ & $\mathrm{oz} 4 \mathrm{c}$ & $1.00 \mathrm{E}-02$ & $5.06 \mathrm{E}+08$ \\
\hline 41 & Ss_57 & OZCU & ozcu5a & $5.00 \mathrm{E}-06$ & $4.70 \mathrm{E}+08$ \\
\hline 42 & ss_52 & OZCU & ozcu2 & $5.00 \mathrm{E}-06$ & $4.03 \mathrm{E}+08$ \\
\hline 43 & ss_54 & OZCU & ozcu3 & $5.00 \mathrm{E}-06$ & $3.92 \mathrm{E}+08$ \\
\hline 44 & ss_59 & OZCU & ozcu6 & $5.00 \mathrm{E}-06$ & $3.58 \mathrm{E}+08$ \\
\hline 45 & ss_56 & OZCU & ozcu5b & $5.00 \mathrm{E}-06$ & $3.51 \mathrm{E}+08$ \\
\hline 46 & ss_73 & OA & oz8 & $1.14 \mathrm{E}-05$ & $3.19 \mathrm{E}+08$ \\
\hline 47 & ss_60 & OZCU & ozcu7 & $5.00 \mathrm{E}-06$ & $2.80 \mathrm{E}+08$ \\
\hline 48 & ss_55 & OZCU & ozcu4 & $5.00 \mathrm{E}-06$ & $2.71 \mathrm{E}+08$ \\
\hline 49 & ss_61 & $\mathrm{OA}$ & oz1 & $1.22 \mathrm{E}-05$ & $2.63 \mathrm{E}+08$ \\
\hline 50 & ss_62 & $\mathrm{OA}$ & oz2 & $1.24 \mathrm{E}-05$ & $1.64 \mathrm{E}+08$ \\
\hline 51 & ss_64 & $\mathrm{OA}$ & oz4d & 2.62E-05 & $1.30 \mathrm{E}+08$ \\
\hline 52 & rch_80 & -- & -- & $8.00 \mathrm{E}-04$ & $1.02 \mathrm{E}+08$ \\
\hline 53 & ss_72 & $\mathrm{OA}$ & oz7 & 2.62E-05 & $8.69 \mathrm{E}+07$ \\
\hline 54 & ss_71 & $\mathrm{OA}$ & oz6 & $3.97 \mathrm{E}-05$ & $6.28 \mathrm{E}+07$ \\
\hline 55 & vk_44 & $\mathrm{OA}$ & oz5a & 0.1 & $5.06 \mathrm{E}+07$ \\
\hline 56 & vk_43 & $\mathrm{OA}$ & oz4 & 0.1 & $5.06 \mathrm{E}+07$ \\
\hline 57 & hk_25 & $\mathrm{OA}$ & oz10 & 0.10701 & $4.82 \mathrm{E}+07$ \\
\hline 58 & hk_21 & $\mathrm{OA}$ & oz6 & 0.10538 & $4.60 \mathrm{E}+07$ \\
\hline 59 & hk_22 & $\mathrm{OA}$ & oz7 & 0.25777 & $1.95 \mathrm{E}+07$ \\
\hline 60 & vk_39 & $\mathrm{OA}$ & oz4d & 0.1 & $1.40 \mathrm{E}+07$ \\
\hline 61 & vk_42 & $\mathrm{OA}$ & oz4a & 0.37003 & $1.35 \mathrm{E}+07$ \\
\hline 62 & hk_15 & $\mathrm{OA}$ & $\mathrm{oz} 4 \mathrm{c}$ & 0.10144 & $1.33 \mathrm{E}+07$ \\
\hline 63 & vk_37 & $\mathrm{OA}$ & oz2 & 0.40034 & $1.25 \mathrm{E}+07$ \\
\hline 64 & hk_23 & $\mathrm{OA}$ & oz8 & 0.98124 & $5.16 \mathrm{E}+06$ \\
\hline 65 & vk_41 & $\mathrm{OA}$ & oz4b & 0.37003 & $3.68 \mathrm{E}+06$ \\
\hline 66 & hk_17 & $\mathrm{OA}$ & oz4a & 0.37003 & $3.67 \mathrm{E}+06$ \\
\hline 67 & hk_14 & $\mathrm{OA}$ & oz4d & 1.5197 & $3.37 \mathrm{E}+06$ \\
\hline 68 & hk_24 & $\mathrm{OA}$ & oz9 & 1.5897 & $3.16 \mathrm{E}+06$ \\
\hline 69 & hk_11 & $\mathrm{OA}$ & oz1 & 1.8083 & $2.81 \mathrm{E}+06$ \\
\hline 70 & hk_19 & $\mathrm{OA}$ & oz5a & 0.61192 & $2.26 \mathrm{E}+06$ \\
\hline 71 & hk_13 & $\mathrm{OA}$ & oz3 & 5 & $1.01 \mathrm{E}+06$ \\
\hline 72 & vk_46 & $\mathrm{OA}$ & oz6 & 0.1 & 826056 \\
\hline 73 & vk_47 & $\mathrm{OA}$ & oz7 & 0.1 & 777884 \\
\hline 74 & vk_49 & $\mathrm{OA}$ & oz9 & 0.14 & 598346 \\
\hline
\end{tabular}


Table 7. Sensitivity of model to changes in parameter values within the Ozark aquifer and Ozark confining unit.-Continued

[OZCU, Ozark confining unit; OA, Ozark aquifer; vk, vertical hydraulic conductivity (feet per day); hk, horizontal hydraulic conductivity (feet per day); ss, specific storage (1/feet); rch, recharge (feet per day; zones shown on fig. 7); ghb, general head boundary conductance; --, not applicable]

\begin{tabular}{lllclc}
\hline Rank & Parameter & Unit name & $\begin{array}{c}\text { Zone name } \\
\text { (from } \\
\text { figure 13) }\end{array}$ & $\begin{array}{c}\text { Calibrated } \\
\text { parameter } \\
\text { value } \\
\text { (variable } \\
\text { units) }\end{array}$ & $\begin{array}{c}\text { Composite } \\
\text { sensitivity } \\
\text { value }\end{array}$ \\
\hline 75 & hk_20 & OA & oz5a & 0.51559 & 311665 \\
76 & vk_45 & OA & oz5a & 0.4923 & 267032 \\
77 & hk_18 & OA & oz4 & 0.34826 & 210850 \\
78 & hk_12 & OA & oz2 & 0.40035 & 204770 \\
79 & vk_38 & OA & oz3 & 0.5 & 162418 \\
80 & hk_16 & OA & oz4b & 2.3456 & 88481.8 \\
81 & vk_48 & OA & oz8 & 0.98124 & 68399.9 \\
82 & vk_36 & OA & oz1 & 1.8083 & 65747.6 \\
83 & ghb_83 & layer 2 & layer 2 & 1 & 4369.99 \\
84 & ghb_84 & layer 4 & layer 4 & 1 & 4303.26 \\
\hline
\end{tabular}




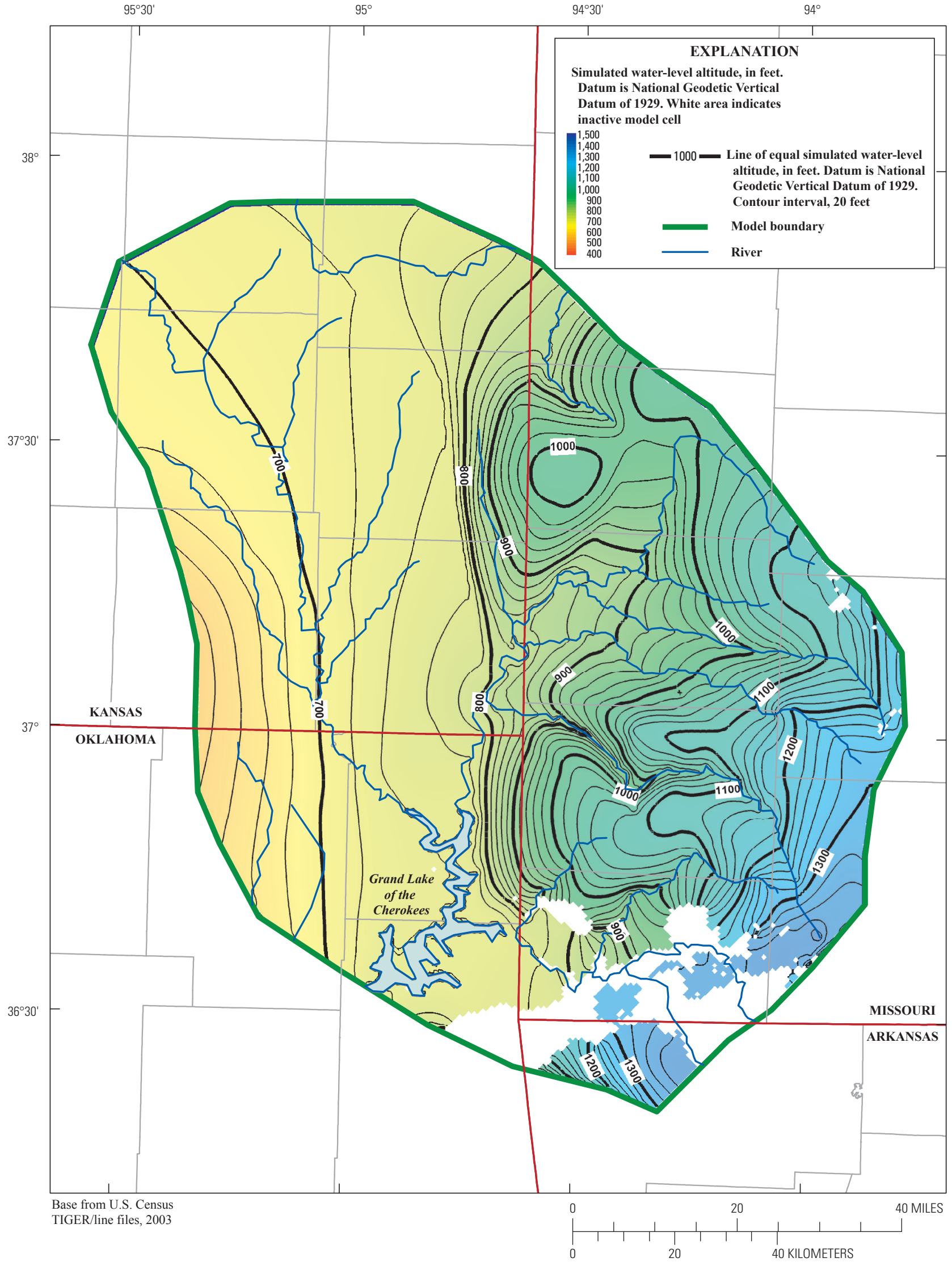

Figure 23. Simulated predevelopment water-level altitudes in the Springfield Plateau aquifer (layer 2). 


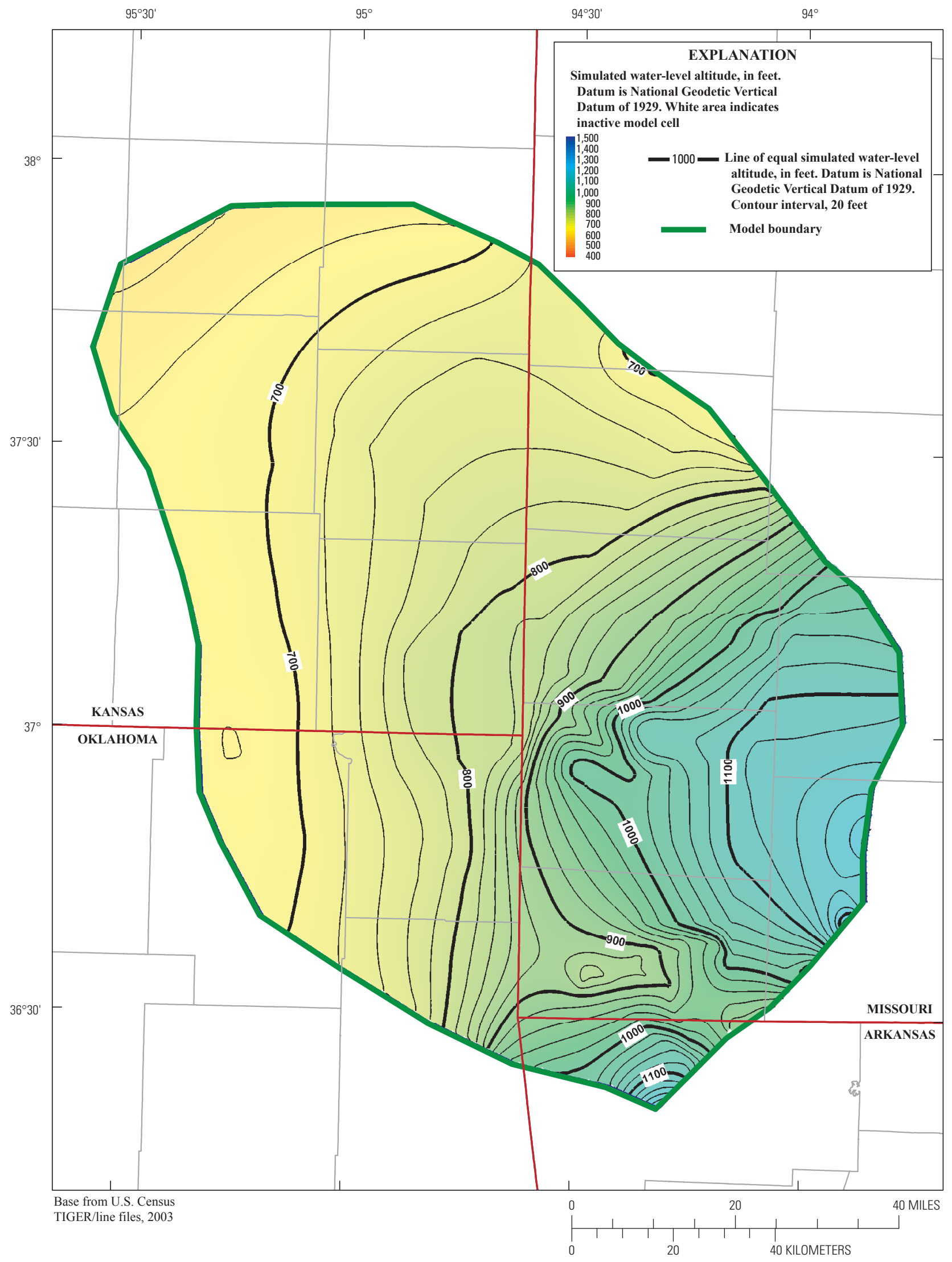

Figure 24. Simulated predevelopment water-level altitudes in the Ozark aquifer. 


\section{Hypothetical Scenarios}

Five hypothetical scenarios were analyzed with the calibrated model to assess changes in water levels in the Ozark aquifer (the predominant source of groundwater within the Ozark Plateau aquifer system) associated with increases in pumping rates (table 8). Pumping rates for each hypothetical scenario were increased from 0 (baseline) to 4 percent of the 2006 pumping rate specified in the model and run for 50 years from 2007 to 2057. For each hypothetical scenario, water-level altitudes were simulated within the model area for the Ozark aquifer (figs. 25, 27, 29, 31, and 33), and hydrographs were created for five pumping centers within the model area located at Pittsburg, Kansas; Miami, Oklahoma; Joplin, Missouri; Carthage, Missouri; and Noel, Missouri (figs. 26, 28, 30, 32, and $34)$. Declines in water-level altitudes from simulated predevelopment conditions to the end of 2057 in the Ozark aquifer at the five pumping centers are listed in table 9 . As pumping rates are increased, the magnitude of water-level altitude change increases. Model cells in four of the pumping centers go dry (Carthage, Joplin, and Noel, Missouri; and Miami, Oklahoma) in the various hypothetical scenarios presented, one as early as 2029 (Carthage, Missouri; hypothetical scenario 5). Even under a 1 percent increase in pumping per year, model cells at Carthage and Noel, Missouri, go dry by years 2037 and 2057, respectively (fig. 28), indicating that pumping at 2006 rates is the maximum rate that can be pumped without model cells in those pumping centers going dry. The altitude of $-900 \mathrm{ft}$ used to denote the occurrence of dry cells is for graphical purposes only and does not indicate the actual bottom of the Ozark aquifer at each pumping center location.
Table 8. Hypothetical pumping scenarios.

\begin{tabular}{ccc}
\hline $\begin{array}{c}\text { Hypothetical } \\
\text { scenario } \\
\text { number }\end{array}$ & $\begin{array}{c}\text { Pumping increase per } \\
\text { year from Ozark aquifer } \\
\text { in Oklahoma and } \\
\text { Missouri after 2006 } \\
\text { (percent) }\end{array}$ & $\begin{array}{c}\text { Pumping increase } \\
\text { per year from Ozark } \\
\text { aquifer in Kansas } \\
\text { after 2006 } \\
\text { (percent) }\end{array}$ \\
\hline 1 & 0 & 0 \\
2 & 1 & 1 \\
3 & 1 & 0 \\
4 & 2 & 2 \\
5 & 4 & 4 \\
\hline
\end{tabular}

Note that when a model cell goes dry, the cell becomes inactive for the duration of that simulation. If a model cell goes dry, any pumping from that cell is turned off from that point forward once the cell becomes inactive. In reality, pumping likely would be intermittent and spatially distributed in an attempt to minimize the lowering of water levels and reduction of well yields.

A comprehensive evaluation of the effect of groundwater pumping on groundwater flow to all rivers in the model was not performed as part of this study. However, because the city of Joplin, Missouri, receives a substantial part of its water supply from Shoal Creek in Newton County, a comparison of groundwater flow to the lower reach (reach 4 on figure 8) was made for hypothetical scenarios $1,2,3,4$, and 5 . The reduction in groundwater flow to that reach from 2006 to the end of 2057 was $10,14,12,16$, and 19 percent, respectively, for these hypothetical scenarios.

Table 9. Decline in water-level altitude from simulated predevelopment conditions to the end of 2057 at five pumping centers in the Ozark aquifer based on the hypothetical pumping scenarios.

[Dry, simulated water level below center of model cell]

\begin{tabular}{cccccc}
\hline $\begin{array}{c}\text { Hypothetical } \\
\text { scenario } \\
\text { number }\end{array}$ & $\begin{array}{c}\text { Pittsburg, } \\
\text { Kansas }\end{array}$ & $\begin{array}{c}\text { Miami, } \\
\text { Oklahoma }\end{array}$ & $\begin{array}{c}\text { Joplin, } \\
\text { Missouri }\end{array}$ & $\begin{array}{c}\text { Carthage, } \\
\text { Missouri }\end{array}$ & $\begin{array}{c}\text { Noel, } \\
\text { Missouri }\end{array}$ \\
\cline { 2 - 6 } & 169 & 330 & 493 & 650 & 583 \\
2 & 245 & 508 & 596 & Dry & Dry \\
3 & 210 & 505 & 593 & Dry & Dry \\
4 & 302 & 644 & 756 & Dry & Dry \\
5 & 505 & Dry & Dry & Dry & Dry \\
\hline
\end{tabular}




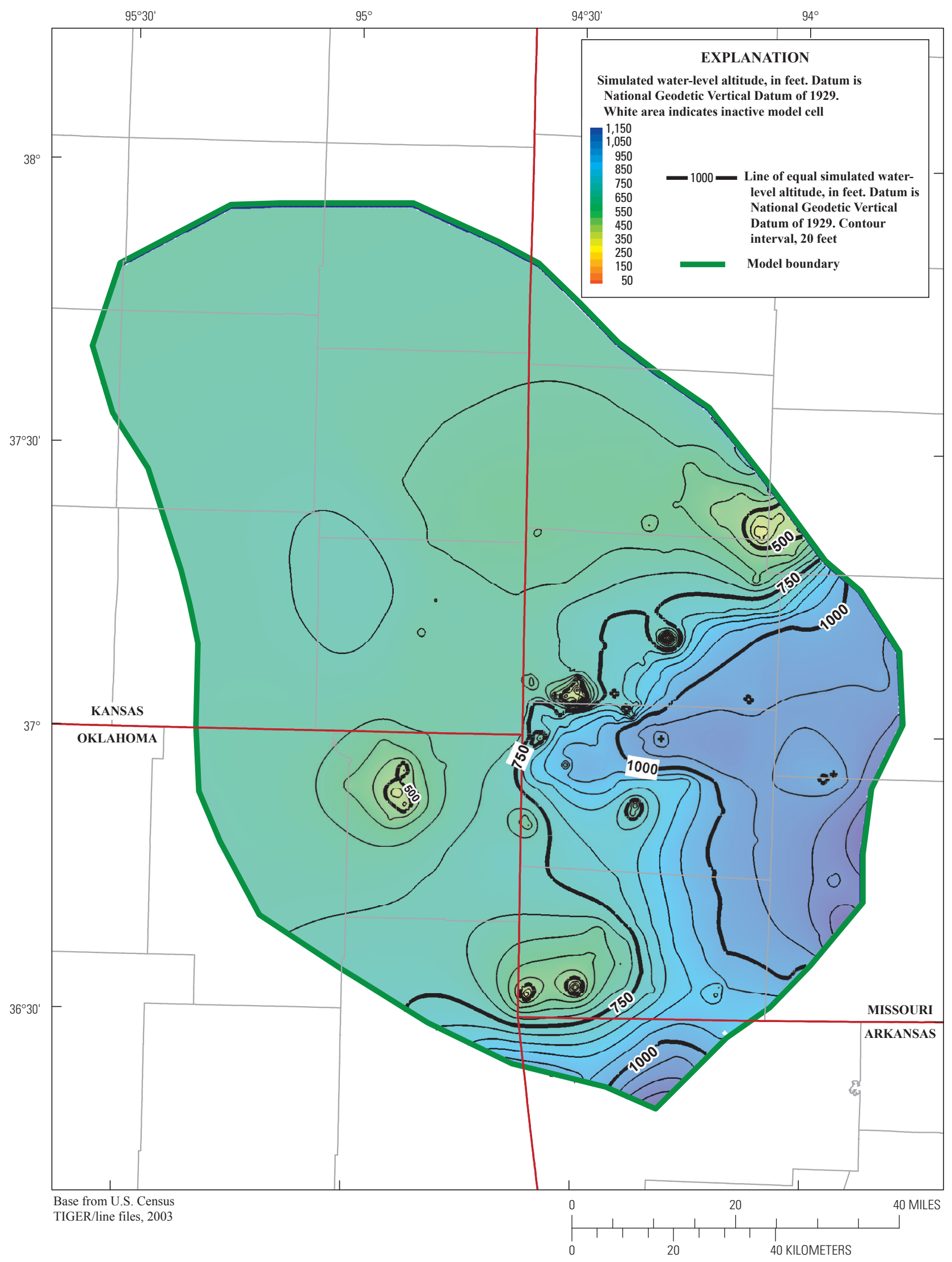

Figure 25. Simulated water-level altitudes at the end of 2057 in the Ozark aquifer for hypothetical scenario 1. 


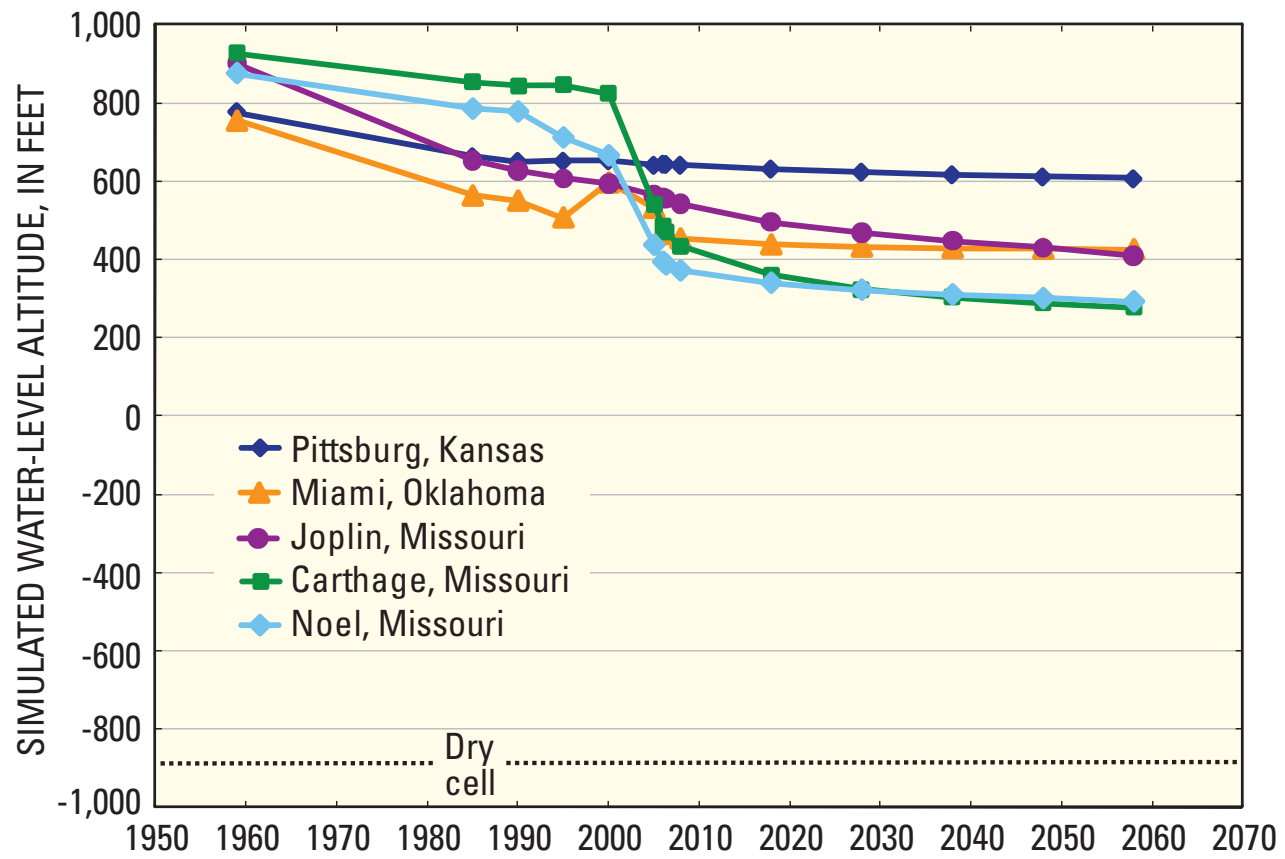

Figure 26. Simulated water-level altitude with time at five pumping centers in the model area for hypothetical scenario 1. 


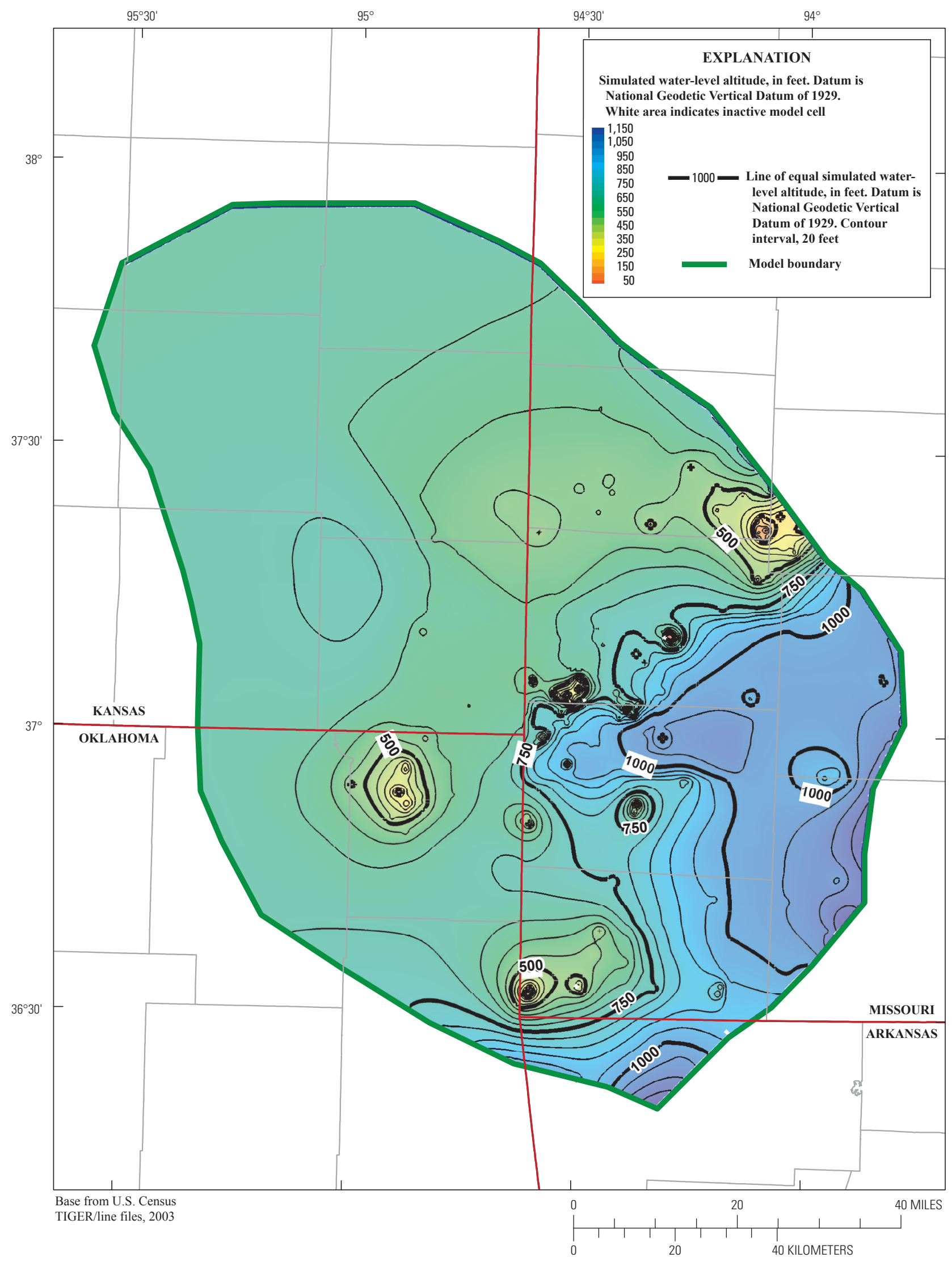

Figure 27. Simulated water-level altitudes at the end of 2057 in the Ozark aquifer for hypothetical scenario 2. 


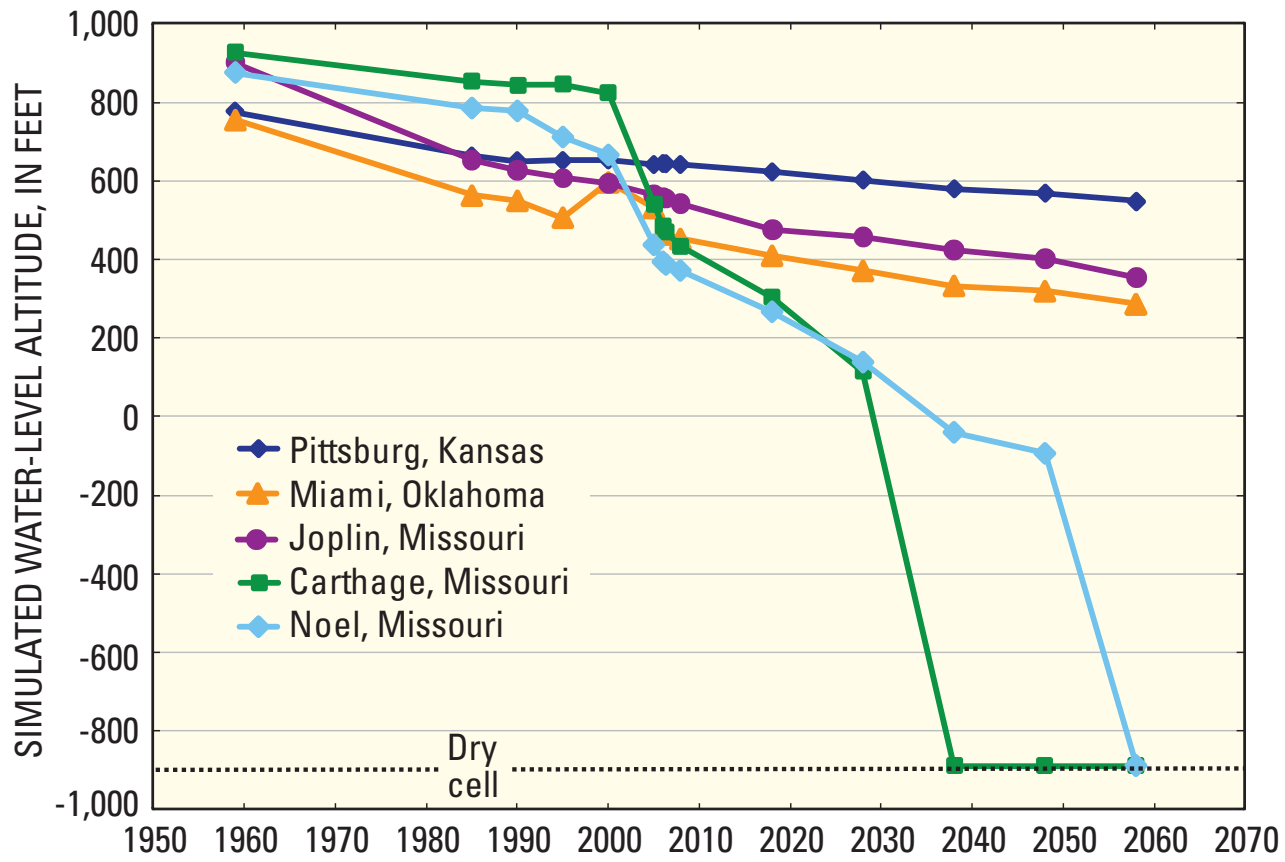

Figure 28. Simulated water-level altitude with time at five pumping centers in the model area for hypothetical scenario 2. 


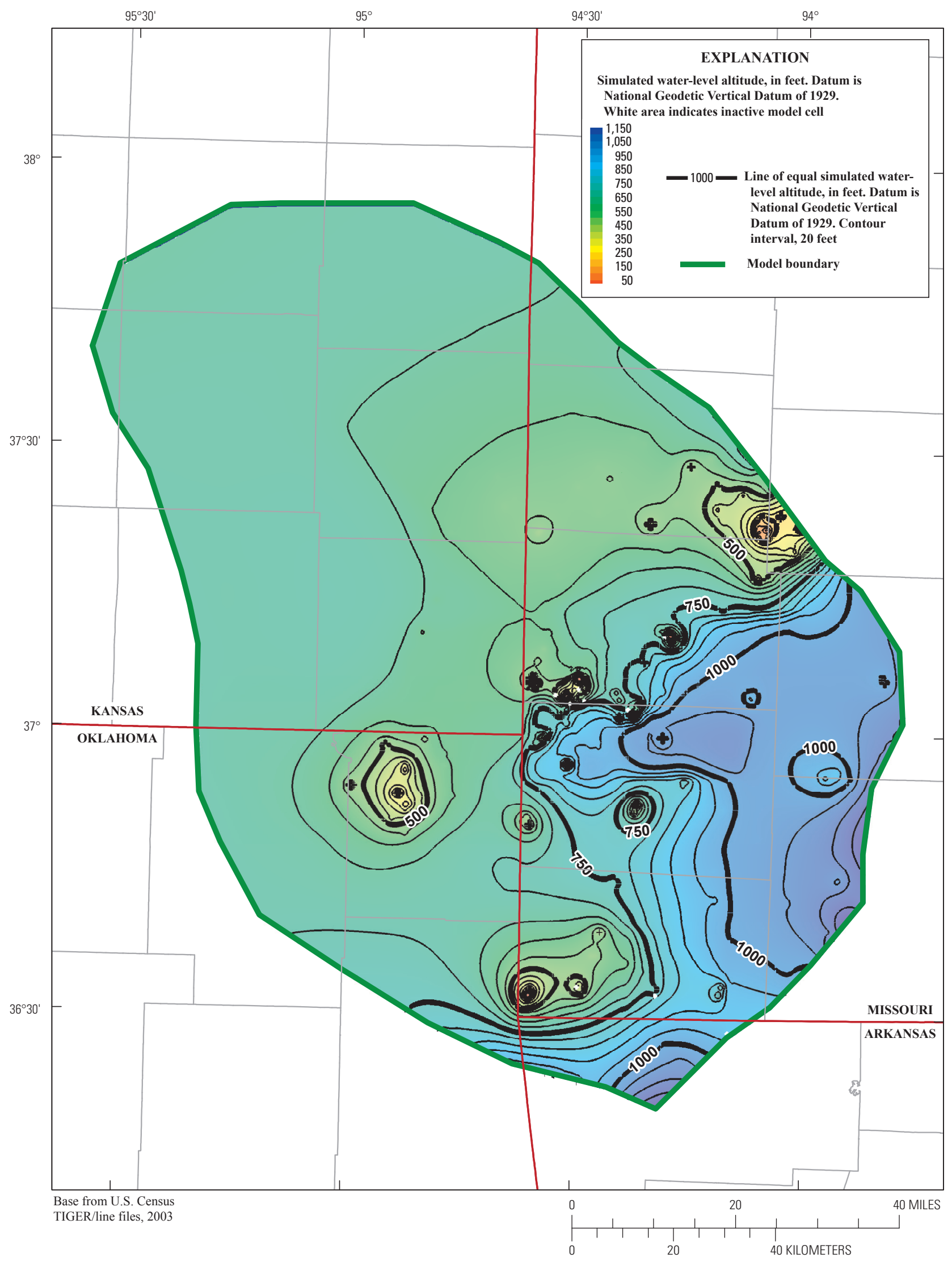

Figure 29. Simulated water-level altitudes at the end of 2057 in the Ozark aquifer for hypothetical scenario 3. 


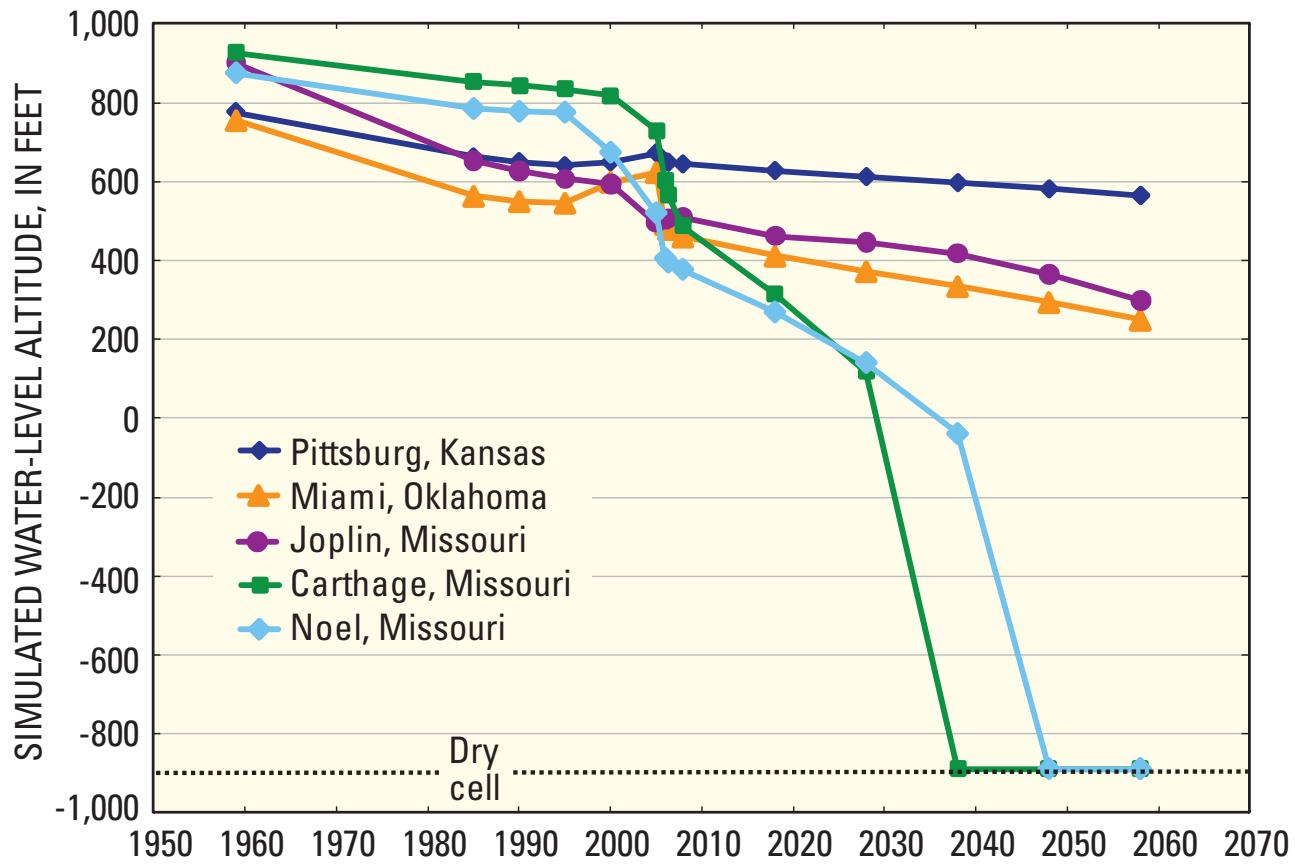

Figure 30. Simulated water-level altitude with time at five pumping centers in the model area for hypothetical scenario 3. 


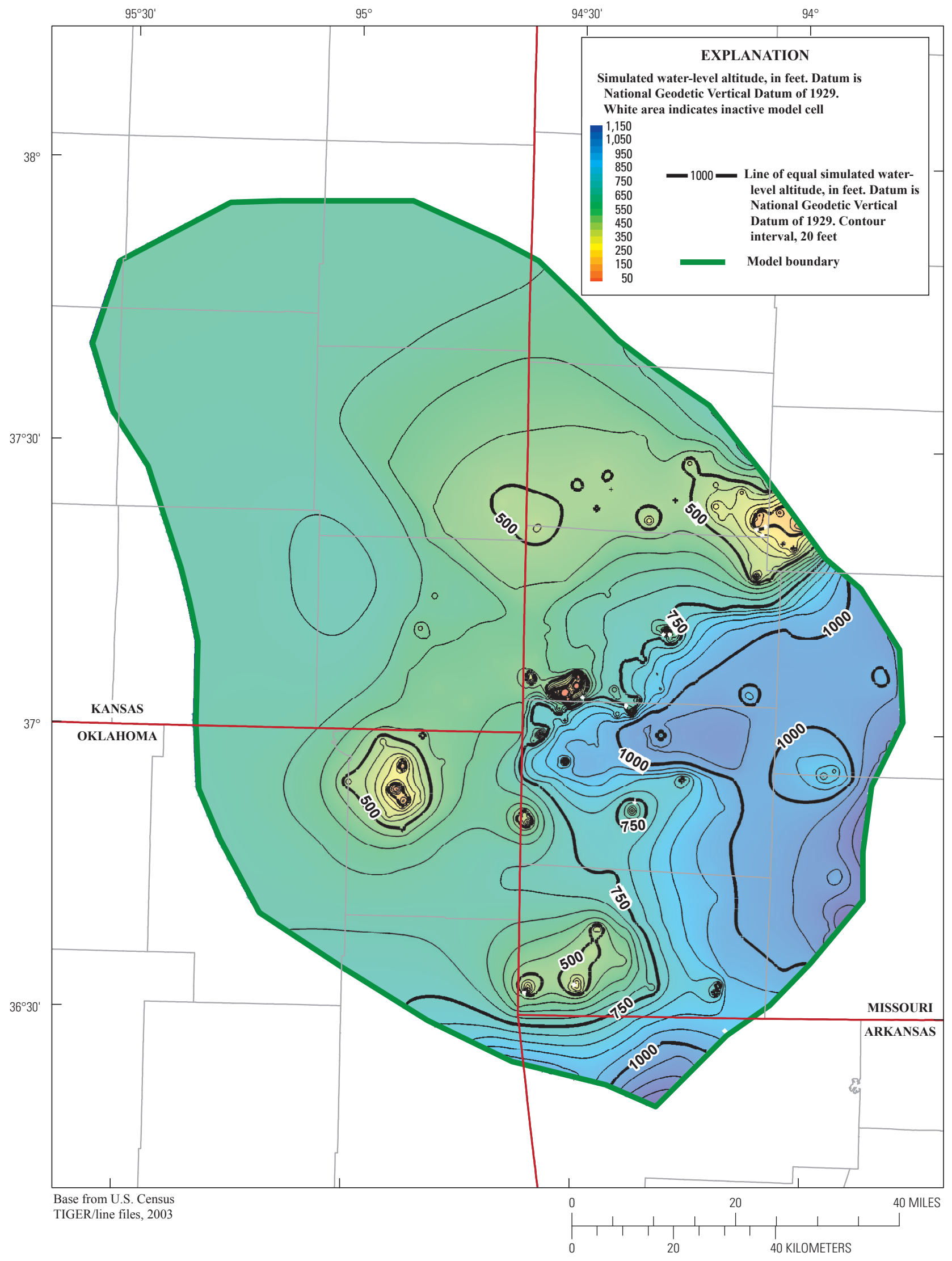

Figure 31. Simulated water-level altitudes at the end of 2057 in the Ozark aquifer for hypothetical scenario 4. 


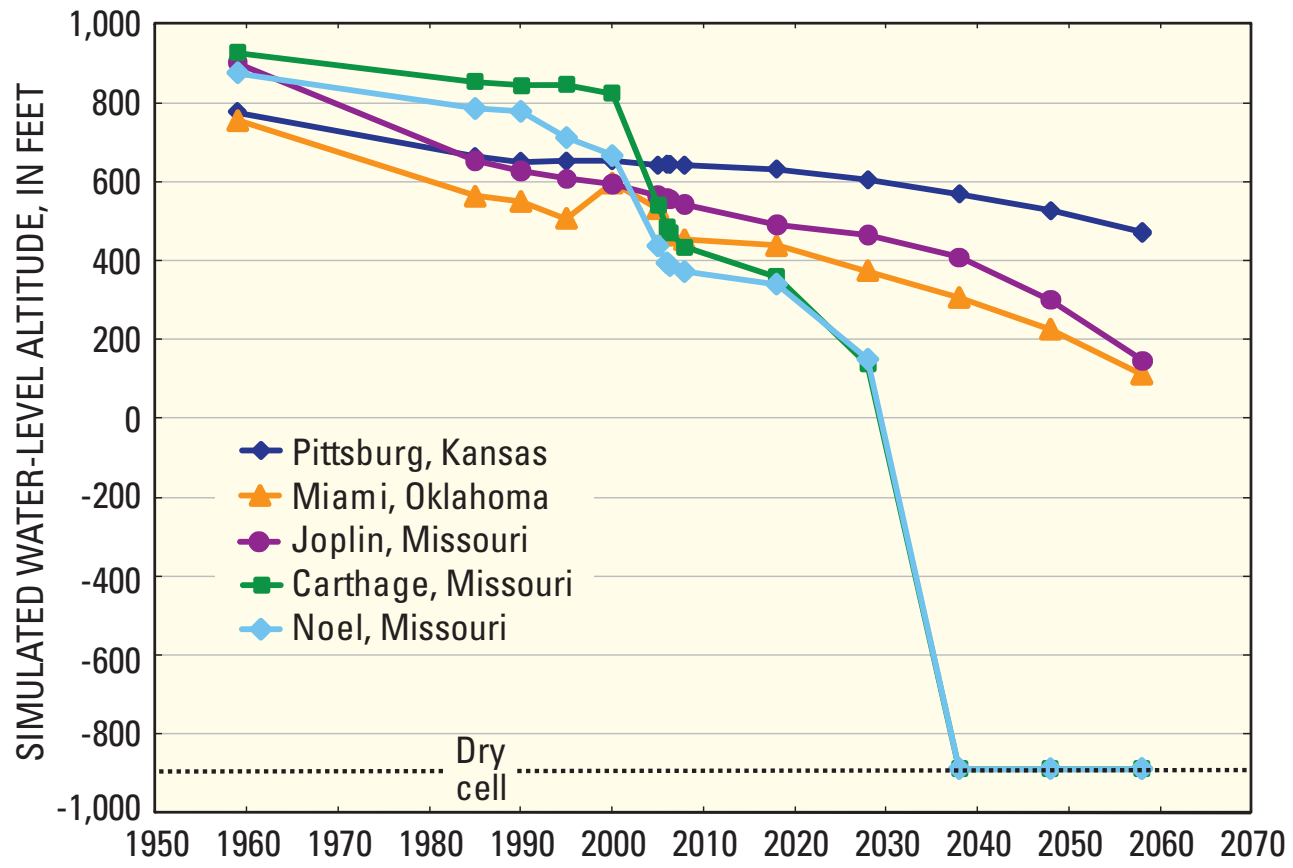

Figure 32. Simulated water-level altitude with time at five pumping centers in the model area for hypothetical scenario 4. 


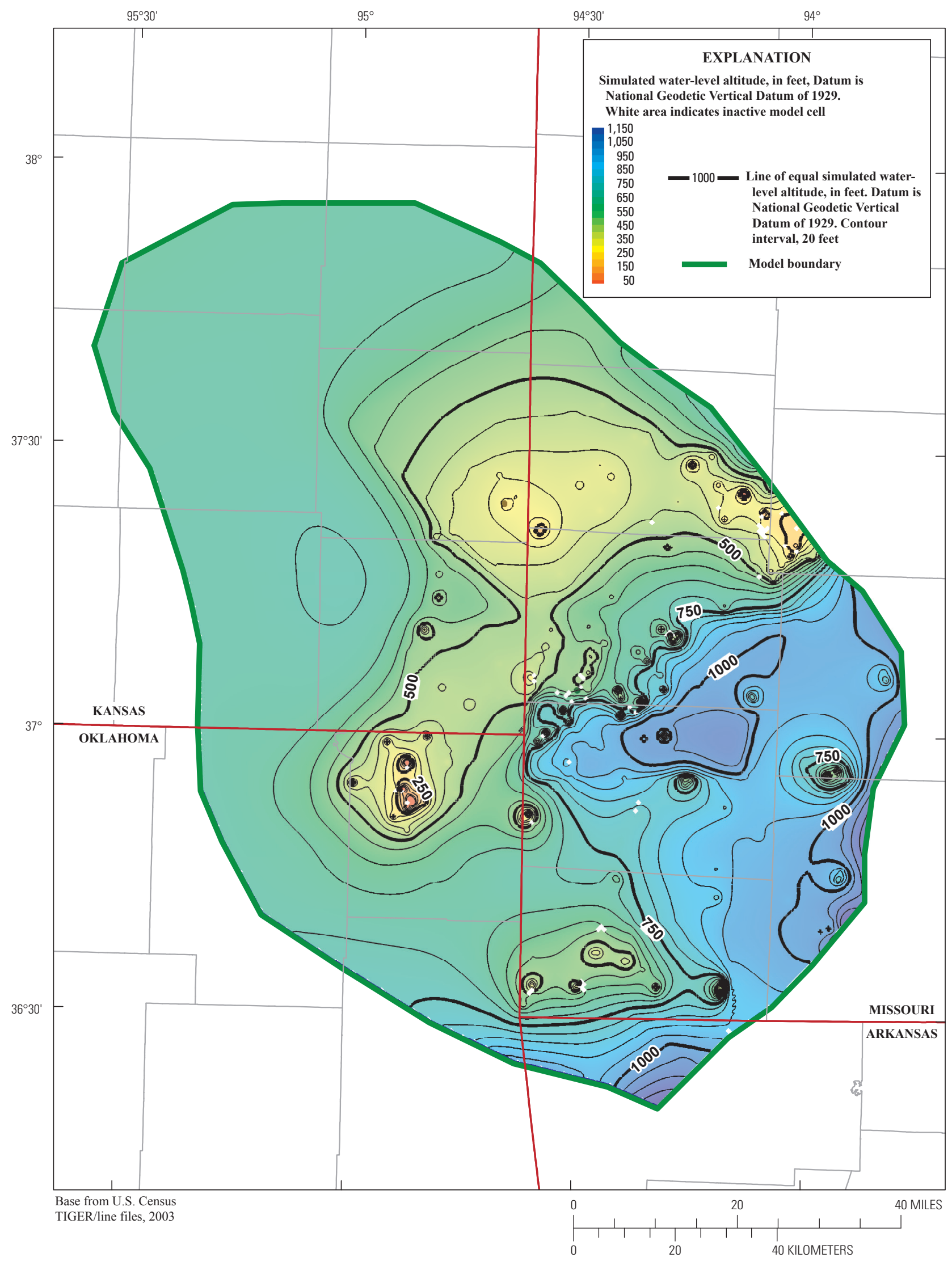

Figure 33. Simulated water-level altitudes at the end of 2057 in the Ozark aquifer for hypothetical scenario 5 . 


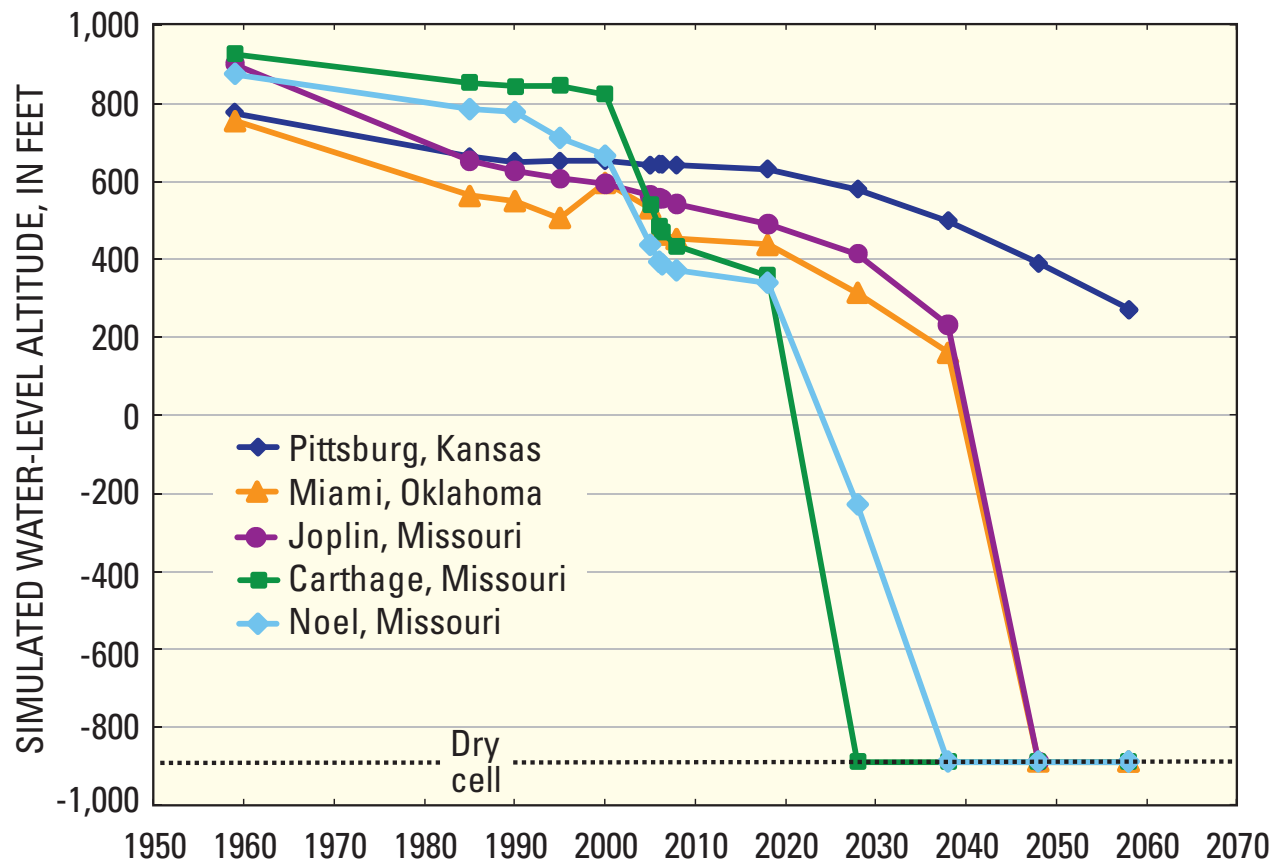

Figure 34. Simulated water-level altitude with time at five pumping centers in the model area for hypothetical scenario 5 .

\section{Zone-Budget Analysis}

To assess the effect that hypothetical changes in pumping rates to the end of 2057 may have on flow rates in the model, a water budget was performed on subareas or zones within the model (zone-budget analysis). Three zones were defined within the model for the Ozark aquifer (fig. 35): zone 1 comprises all of the Ozark aquifer within Kansas, zone 2 comprises all of the Ozark aquifer within Oklahoma, and zone 3 comprises all of the Ozark aquifer in Missouri and Arkansas. Zone 4 comprises all of the overlying Ozark confining unit.

The rationale for dividing the zones within the Ozark aquifer along State lines was made partly for convenience, although the distribution of wells is affected partly by differing water laws in each State, which results in differences in well density and water use (fig. 12). The Kansas Water Appropriation Act (KWAA) is the principal law under which Kansas water is governed. Kansas is a "prior appropriation" State as to water rights. It is illegal to use water for any purpose, except for domestic use, without having a vested right or a permit from the Division of Water Resources (DWR) within the Kansas Department of Agriculture (KDOA) to appropriate water. The DWR keeps all water rights records for Kansas. Agricultural producers need to contact DWR for information about required permits before beginning any water-use activity. All water is considered owned by the State but dedicated to citizens' use under the principal of "first in time, first in right." In times of shortages, any water restrictions are first applied to the water rights last or most recently acquired, then applied to the next to last acquired, and so on. However, in addition to this priority principle, other management techniques are allowed in special areas called Intensive Groundwater Use Control Areas (IGUCAs) established by the DWR (National Association of State Departments of Agriculture Research Foundation, 2009). Missouri water law is based on the principle of "reasonable use." According to the Missouri Supreme Court, reasonable use "depends on many factors including persons involved, their relative positions, nature of their uses, comparative value of their uses, climatic conditions, and all facts and circumstances pertinent to the issues. It is that legal standard, in absence of statutory expression, by which existing water resources may be allocated most equitably and beneficially among competing users, private and public" (Gaffney and Hays, 2000). Oklahoma water law is considered private property that belongs to the overlying surface owner, although it is subject to reasonable regulation by the Oklahoma Water Resources Board (Oklahoma Water Resources Board, 2009). No water use was simulated in the model area for Arkansas.

Flow into and out of Kansas (zone 1), with respect to the other three zones, is listed in table 10 for all five hypothetical scenarios. Other sources and sinks representing flow terms are flow resulting from the release of water in storage, flow into or out of general-head boundaries, and flow out of the model toward wells. Differences between the total flow in and total flow out of a zone are attributable to model mass-balance error, which typically is less than 0.001 percent for all five hypothetical scenarios.

The largest component of flow into zone 1 comes from downward flow from the overlying Ozark confining unit (zone 4 ) in the lesser pumping scenarios (1-3), and varies from 21 


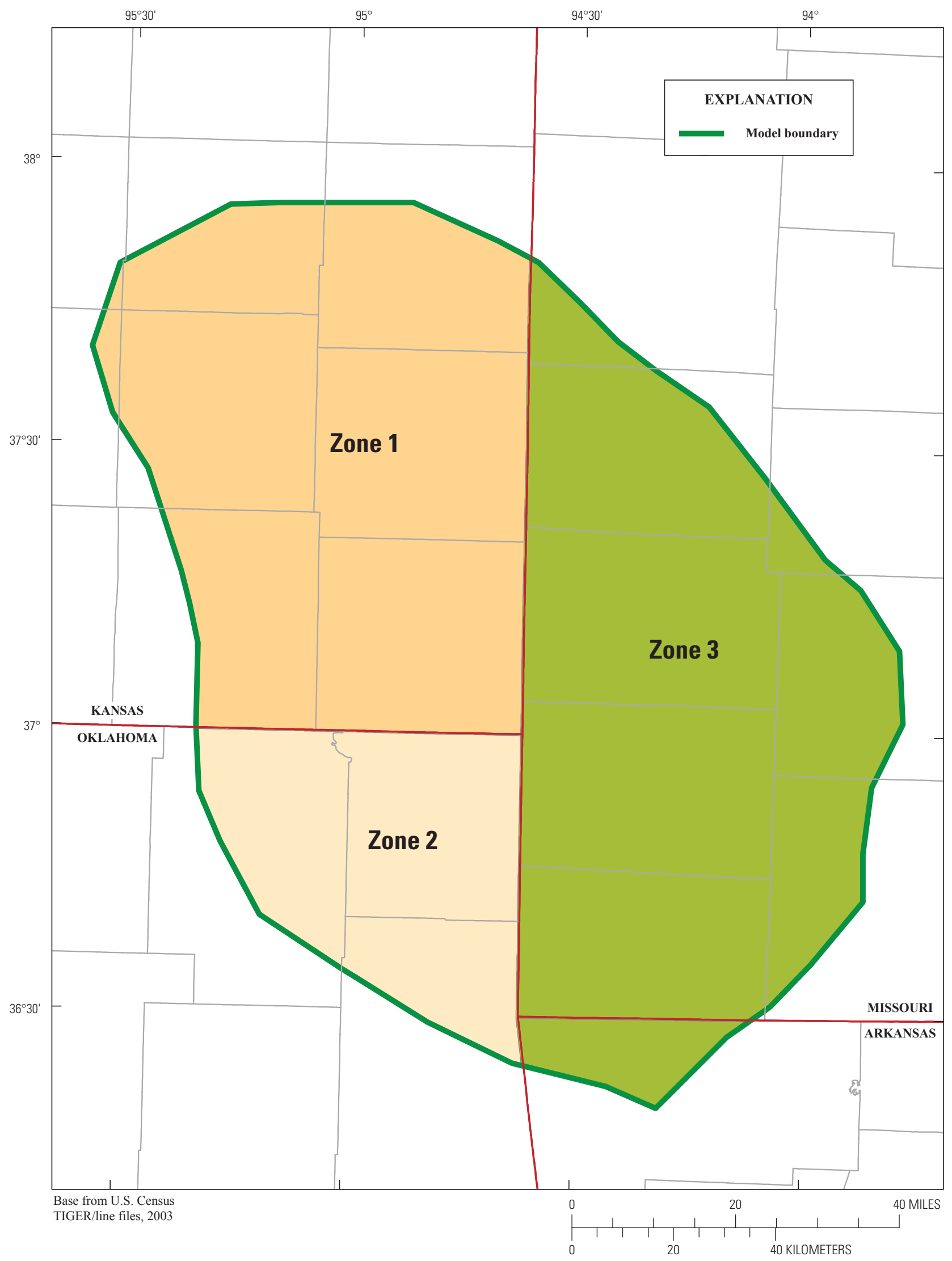

Figure 35. Zones used in the Ozark aquifer (layer 4) for zone-budget analyses. 
to 41 percent of the total flow into zone 1 in the different scenarios. As pumping in zone 1 increases, the amount of water released from storage increases and ranges from 26 to 53 percent. This increase is consistent with the increased size in cones of depression in zone 1. The largest component of flow out of zone 1 (the Kansas part of the model) occurs as pumping from wells, which ranges from 39 to 61 percent for all the scenarios. The second largest flow component out of zone 1 is flow from zone 1 to zone 3 (Missouri and Arkansas part of the model). This flow rate, which ranges from 30 to 43 percent of the total flow out of zone 1, is induced by pumping that occurs in zone 3 (figs. 25, 27, 29, 31, and 33). Net simulated flow (the difference between flow into and flow out of two adjacent zones) in 2057 from Kansas (zone 1) to Missouri (zone 3) ranges from $74,044 \mathrm{ft}^{3} / \mathrm{d}$ for 2006 pumping rates (scenario 1) to $625,319 \mathrm{ft}^{3} / \mathrm{d}$ for a 4 percent increase per year (scenario 5).

The largest component of flow into zone 2 (the Oklahoma part of the model) comes from zone 4 (the overlying Ozark confining unit), which is consistently about 45 percent of the total (table 11). Flow from the release of water in storage, from general head boundaries, and from zones 1 and 3 are considerably smaller values that range from 3 to 22 percent of the total flow into zone 2. The largest flow out of zone 2 occurs from pumping from wells, and ranges from 52 to 69 percent of the total. The percentage of flow from water released from storage increases from 3 to 20 percent with the increase in water pumped from wells (52 to 69 percent) for zone 2, which like zone 1, is the largest component of flow out of zone 2.

The largest percentage of flow into zone 3 (the Missouri and Arkansas part of the model) comes from the overlying Ozark confining unit (zone 4) for scenario 1, the baseline scenario in which 2006 pumping rates are maintained from 2006 through to the end of 2057 (table 12). As pumping rates increase, flow from general-head boundaries and water released from storage become larger than the contribution from zone 4. Pumping from wells completed in the Ozark aquifer is the largest component of flow out of zone 3 , and varies between 88 to 91 percent of the total flow out of zone 3 for all of the scenarios.

When pumping rates (for 2006) for zones 1, 2, and 3 are summed for scenario 1, pumping from zone $3\left(8,531,520 \mathrm{ft}^{3} / \mathrm{d}\right)$ is 87 percent of the total $\left(9,810,380 \mathrm{ft}^{3} / \mathrm{d}\right)$, pumping from zone $1\left(727,452 \mathrm{ft}^{3} / \mathrm{d}\right)$ is 7 percent of the total, and pumping from zone $2\left(551,408 \mathrm{ft}^{3} / \mathrm{d}\right)$ is 6 percent of the total. The magnitude of pumping in zone 3 and the proximity of pumping wells to general-head boundaries induces more flow from the generalhead boundary than occurs in zones 1 or 2 from general-head boundaries. Because of this condition, water-level altitudes in parts of zone 3 are propped up by the invariant water-level altitude specified at the general-head boundary where cones of depression intercept the boundary, limiting decreases in water levels. Additionally, dry cells occur in some cones of depression, which, when they occur, cause any pumping that may have been occurring there to be turned off from the point in time when the cell went dry until the end of simulation.
Hence, the total pumping rates reported in tables 10 through 12 are probably less than they would have been had dry cells not occurred.

\section{Model Limitations}

The groundwater-flow model described in this report is useful in evaluating the flow system in the model area. However, the model represents a simplification of the flow system, and the following limitations should be considered. Flow in the Springfield Plateau and Ozark aquifers is primarily through fractures and bedding planes. Modeling this flow as equivalent to flow through a uniformly porous media may introduce error. The steady-state simulation, used for the initial head conditions, assumes that flows into and out of the model area are equal. If this were not so, the change in groundwater storage (that is, if water levels were actually rising or falling) would be a source of model error. The lack of analyses related to groundwater base flow of rivers or hydrologic properties of the aquifer adds further uncertainty. Model input variables are applied over extended areas, and assumptions of uniformity for heterogeneous geologic materials may produce inaccuracies. Field-test values of hydraulic conductivity and storage terms are few, limiting the ability to constrain hydraulic parameters over their potentially large range. Test analyses that do exist are appropriate for comparison with model parameters in the vicinity of the test, but may not be appropriate for comparison in other areas of the model.

Use of the general-head and river boundaries is with the assumption that specified water-level altitudes at those boundaries are invariant over the entire simulation period, and that the hydraulic-conductance terms associated with those boundaries are well defined, which likely is not the case. Assignment of a no-flow boundary at the bottom of layer 4 of the model was done with the assumption that flow from or to the St. Francois confining unit was minor, but lack of data make this boundary uncertain. Additionally, assignment of a no-flow boundary along part of the northern boundary of the model where the Chesapeake fault occurs was done based on available water-level data (Gillip and others, 2008), which indicated a no-flow boundary. Hydraulic properties associated with these faults were not available, however; therefore, this model assumption cannot be confirmed. The specification of no-flow boundary conditions along parts of the Chesapeake fault, particularly in the vicinity of substantial pumping may be a considerable source of error leading to excessively low simulated water-level altitudes or dry cells, particularly for hypothetical scenarios involving increased pumping. The occurrence of dry cells can result prematurely from specification of values of specific storage and hydraulic conductivity that are too small, recharge that is too small, or water-use values that are too large, or a combination of the three. Because of uncertainties in estimates for these parameters, the occurrence of simulated dry cells should not be considered definitive. 


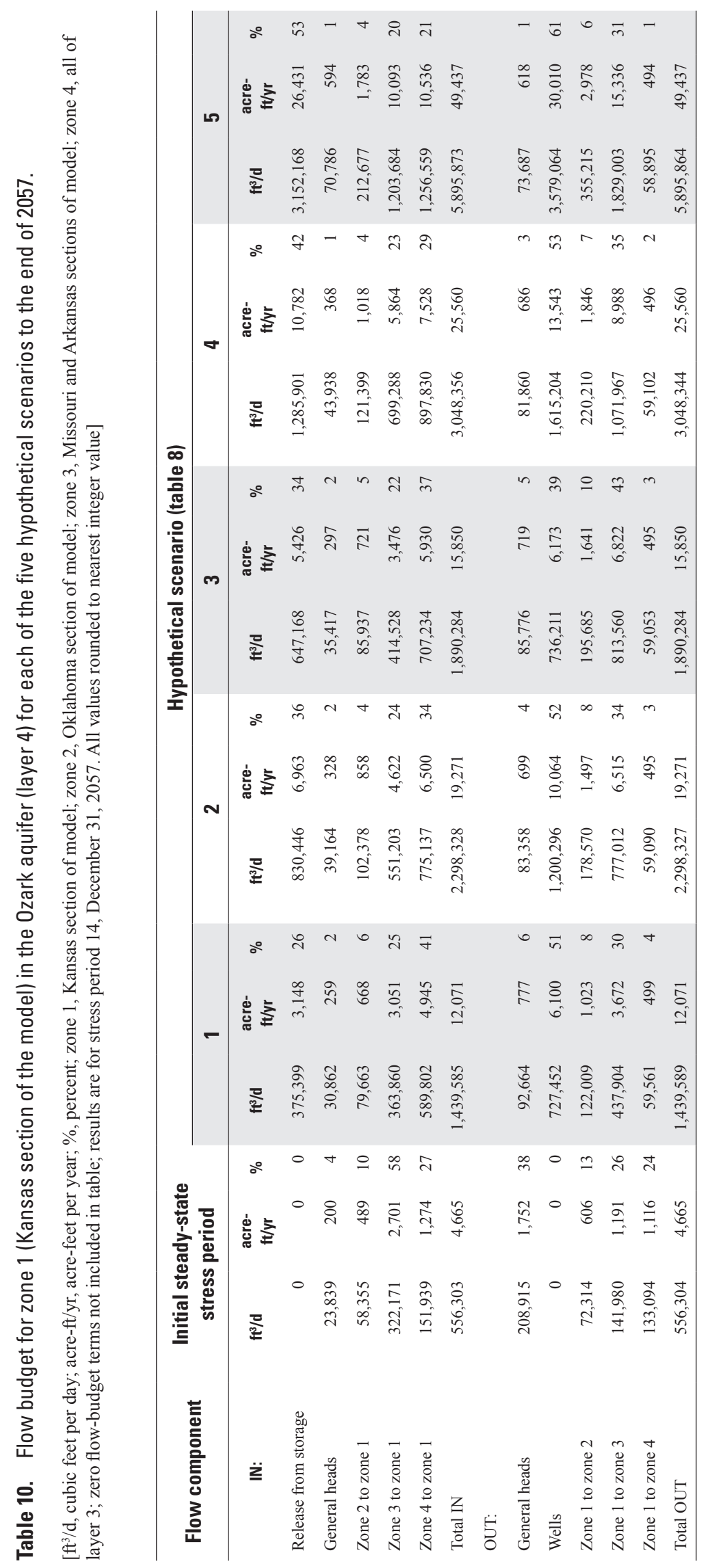




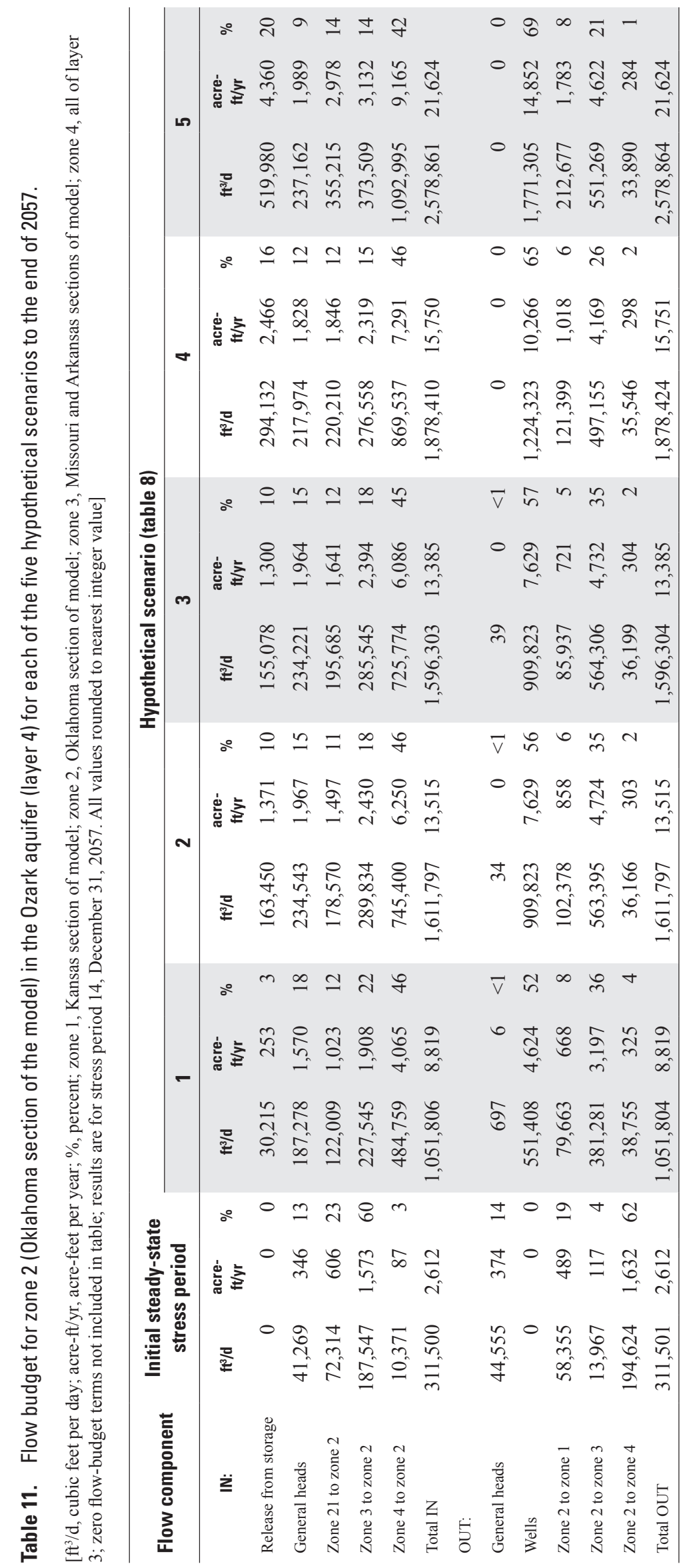




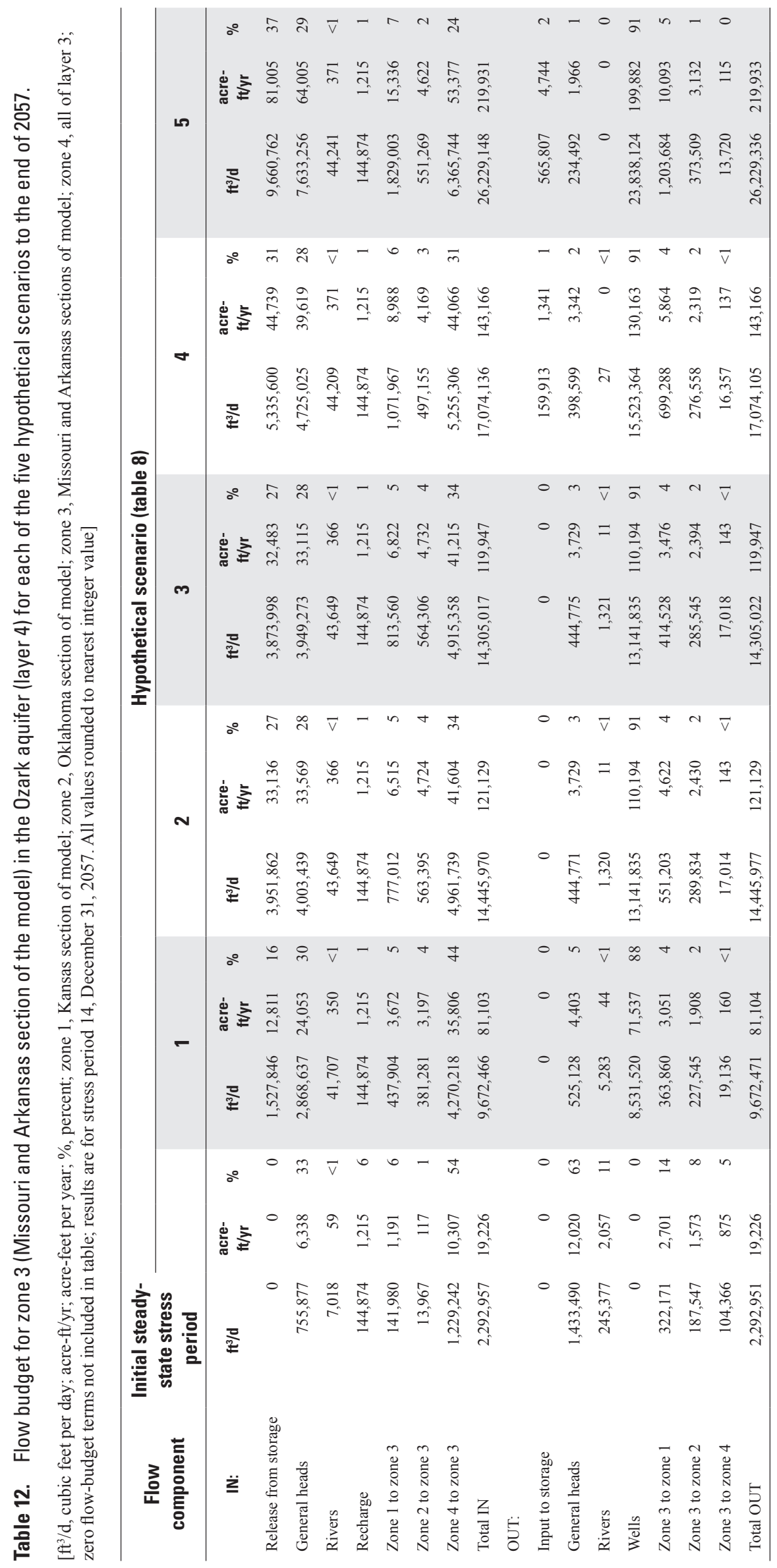


The accuracy of the simulations is limited by the accuracy of the data used to describe the properties of the aquifers and confining units, recharge rates, water use, streambed conductance, and boundary conditions. Improvements in the accuracy of these model inputs are possible but exceed the scope of the current study. Hydraulic testing in the model area is extremely sparse, resulting in poorly constrained values of horizontal and vertical hydraulic conductivity, specific storage, and specific yield. Recharge estimates are minimally available in part because of inadequate data from which to estimate recharge. Accurate reporting of site-specific water-use data has improved with time and is critical to the accuracy of the model, but there are areas in the model (in particular, Oklahoma) that lack site-specific water-use data. Specification of predevelopment water use in the Springfield Plateau aquifer, albeit a very small rate, is likely inaccurate. Conversely, specification of no pumping in the Ozark aquifer during predevelopment time followed by specification of pumping beginning in 1959, makes results for the earlier transient part of the simulation (prior to 1959) less accurate than the latter part (1959-2006). Discrepancies between simulated and observed water-level altitudes may occur because of uncertainties in actual water use from the Ozark aquifer prior to 1959 , and error associated with specifying the horizontal position of an observation well or a pumping well, particularly in areas with large cones of depression, which can translate into large differences in simulated water-level altitude over small horizontal distances. Also, as simulation time increases from 2006 onward, model accuracy likely decreases for the various hypothetical scenarios simulated, particularly in areas where differences between simulated and observed waterlevel altitudes are large. Geologic units specified in the model were based on data developed by Imes and Emmett (1994), but could be refined using existing and future geophysical and drillers' logs. Structural features, in particular hydrologic barriers such as the Miami syncline, were not implemented in the current model, but might improve model fit to observed water-level altitudes.

Transient water-level data from long-term or continuously recording monitor wells were not implemented in the current model as observation data, in part because of uncertainty associated with historic water use. Model estimates of specific storage could be improved with better defined transient water-level altitudes used for model calibration. Estimates of areal recharge values used in the model are general and invariant in time, but might be independently improved and bracketed using approaches that consider slope and aspect of terrain, catchment area, temporal and spatial distribution of precipitation, vegetation and soil type, evapotranspiration, and future changes in climate. Although the model grid used in the current study is finer than other regional models developed in the model area, additional grid refinement and land-surface altitude specification would better represent flow to rivers and springs, and more accurately represent large cones of depression by allowing more precise spatial specification of pumping wells.

\section{Summary}

A groundwater-flow model was developed in cooperation with the Kansas Water Office for an area covering 7,340 square miles for parts of Arkansas, Kansas, Missouri, and Oklahoma to characterize groundwater flow within the Ozark Plateaus aquifer system and assess the effect that increased water use may have on the long-term availability of groundwater. Vertically the model was divided into five units. From top to bottom these units of variable thickness are: the Western Interior Plains confining unit; the Springfield Plateau aquifer; the Ozark confining unit; the Ozark aquifer; and the St. Francois confining unit. Large mined zones contained within the Springfield Plateau aquifer were represented in the model as extensive voids with orders-of-magnitude larger hydraulic conductivity than the adjacent nonmined zones. Water-use data were compiled for the period 1950 to 2006, with the most complete data sets available for the period 1985 to 2006. In 2006, total water use from the Ozark aquifer for Missouri was 87 percent $\left(8,531,520 \mathrm{ft}^{3} / \mathrm{d}\right)$ of the total water use for the model area, with Kansas at 7 percent $\left(727,452 \mathrm{ft}^{3} / \mathrm{d}\right)$, and Oklahoma at 6 percent $\left(551,408 \mathrm{ft}^{3} / \mathrm{d}\right)$; water use for Arkansas within the model area was minor. Calibration of the model against water-level altitudes obtained in 2006 was made for the Springfield Plateau and Ozark aquifers and for average water-level altitudes in the Ozark aquifer for the period 1980 to 1989 . Groundwater flow within the model occurs generally from the highlands of the Springfield Plateau in the southeast toward the west, with localized flow occurring towards rivers and five pumping centers near Joplin, Carthage, and Noel, Missouri; Pittsburg, Kansas; and Miami, Oklahoma. Error in simulating water-level altitudes was greatest where water-level altitude gradients were largest, particularly near large cones of depression. Sensitivity analyses of model parameters showed that the six most sensitive parameters were vertical hydraulic conductivity or horizontal hydraulic conductivity in the Ozark confining unit (layer 2).

Hypothetical scenarios involving various increases in groundwater-pumping rates were analyzed with the calibrated groundwater-flow model to assess possible changes in the flow system to the year 2057. Pumping rates were increased between 0 and 4 percent per year starting with the 2006 rates for all wells in the model. Sustained pumping at 2006 rates was feasible at the five pumping centers until 2057. Model cells in four of the pumping centers go dry (Carthage, Joplin, and Noel, Missouri, and Miami, Oklahoma) in the increased pumping hypothetical scenarios presented, one as early as 2029 (Carthage, Missouri; hypothetical scenario 5). Even under a 1 percent increase in pumping per year, model cells at Carthage and Noel, Missouri go dry by years 2037 and 2057 respectively), indicating that pumping at 2006 rates is the maximum rate that can be pumped without model cells in those pumping centers going dry. The occurrence of dry cells indicates that pumping is not sustainable at those rates. 
Zone-budget analyses were performed for the hypothetical scenarios to the end of 2057 to assess the groundwater flow into and out of three zones specified within the Ozark-aquifer layer of the model. The three zones represented the model parts of the Ozark aquifer in Kansas (zone 1), Oklahoma (zone 2), and Missouri and Arkansas (zone 3). Groundwater pumping causes substantial reductions in water in storage, and induces flow through the Ozark confining unit for all hypothetical scenarios evaluated. Although flow from the Ozark confining unit is substantial, it is not uniformly distributed, and varies spatially based on the vertical hydraulic gradient, Ozark confining unit thickness, and specified vertical hydraulic conductivity value. Net simulated flow in 2057 from Kansas (zone 1) to Missouri (zone 3) ranges from 74,044 ft3 $3 / \mathrm{d}$ for 2006 pumping rates (hypothetical scenario 1) to 625,319 $\mathrm{ft}^{3} / \mathrm{d}$ for a 4 percent increase in pumping per year (hypothetical scenario 5). Pumping from wells completed in the Ozark aquifer is the largest component of flow out of zone 3 , and varies between 88 to 91 percent of the total flow out of zone 3 for all of the hypothetical scenarios. The largest component of flow into the Oklahoma (zone 2) comes from the overlying Ozark confining unit, which is consistently about 45 percent of the total. Flow from the release of water in storage, from general head boundaries, and from zones 1 and 3 are considerably smaller values that range from 3 to 22 percent of the total flow into zone 2. The largest flow out of the Oklahoma part of the model occurs from pumping from wells, and ranges from 52 to 69 percent of the total.

\section{Selected References}

Adamski, J.C., Petersen, J.C., Freiwald, D.A., and Davis, J.V., 1995, Environmental and hydrologic setting of the Ozark Plateaus study unit, Arkansas, Kansas, Missouri, and Oklahoma: U.S. Geological Survey Water-Resources Investigation Report 94-4022, 9 p.

Aquaveo, 2008, Groundwater Modeling System (GMS) available on the World Wide Web, accessed September 1, 2008, at http://www.aquaveo.com/gms

Christenson, S.C., Parkhurst, D.L., and Fairchild, R.W., 1994, Geohydrology and water quality of the Roubidoux aquifer, northeastern Oklahoma: Oklahoma Geological Survey Circular 96, $70 \mathrm{p}$.

DeHay, K.L., Andrews, W.J., and Sughru, M.P., 2004, Hydrology and groundwater quality in the mine workings within the Picher mining district, northeastern Oklahoma, 2002-03: U.S. Geological Survey Scientific Investigations Report 2004-5043, 62 p.

Doherty, John, 1994, PEST: Model-independent parameter estimation user manual: 5th edition: Watermark Numerical Computing, $336 \mathrm{p}$.
Dugan, J.T., and Peckenpaugh, J.M., 1985, Effects of climate, vegetation, and soils on consumptive water use and groundwater recharge to the Central Midwest Regional Aquifer system, Mid-continent United States: U.S. Geological Survey Water-Resources Investigations Report 85-4236, 78 p.

Freeze, R.A., and Cherry, J.A., 1979, Groundwater: Englewood Cliffs, New Jersey, Prentice-Hall, 604 p.

Federal Reserve Bank of St. Louis, 2008, ALFRED: Archival Federal Reserve Economic Data, accessed on December 23, 2008, at http://research.stlouisfed.org/fred2/source? soid=19

Frick, D.R., 1980, Hydrogeology of Mississippian and Ordovician aquifers in southwest Missouri and southeast Kansas: Columbia, University of Missouri, M.S. thesis, 96 p.

Gaffney, Richard, and Hays, Charles, 2000, A summary of Missouri water laws: Missouri Department of Natural Resources Water Resources Report No. 51, 292 p.

Gillip, J.A., Czarnecki, J.B., and Mugel, D., 2008, Potentiometric surfaces in the Springfield Plateau and Ozark aquifers of northwestern Arkansas, southeastern Kansas, southwestern Missouri, and northeastern Oklahoma, 2006: U.S. Geological Survey Scientific Investigations Report 2007-5253, 25 p.

Harbaugh, A.W, Banta, E.R., Hill, M.C., and McDonald, M.G., 2000, MODFLOW-2000, The U.S. Geological Survey modular groundwater model-User guide to modularization concepts and the groundwater flow processes: U.S. Geological Survey Open-File Report 00-92, 209 p.

Hart and Wang, 1995, Laboratory measurements of a complete set of poroelastic moduli for Berea sandstone and Indiana limestone: Journal of Geophysical Research, v. 100, no. B9, p. $17,741-17,451$.

Hedman, E.R., Skelton, J., and Freiwald, 1987, Flow Characteristics for Selected Springs and Streams in the Ozark Subregion, Arkansas, Kansas, Missouri, and Oklahoma, U.S. Geological Survey Hydrologic Investigations Atlas HA-688, sheet 2.

Imes, J.L., 1989, Analysis of the effect of pumping on groundwater flow in the Springfield Plateau and Ozark aquifers near Springfield, Missouri: U.S. Geological Survey WaterResources Investigations Report 89-4079, 63 p.

Imes, J.L. and Emmett, L.F., 1994, Geohydrology of the Ozark Plateau aquifer system in parts of Missouri, Arkansas, Oklahoma, and Kansas: U.S. Geological Survey Professional Paper 1414-D, 127 p.

Kansas Water Office, 2007, Ozark Plateau aquifer management accessed June 10, 2009 at http://www.kwo.org/ Reports\%20\%26\%20Publications/Fact\%20Sheets/Rpt Ozark\%20aquifermanagement_factsheet_111407_mf_kf.pdf 
Lohman, S.W., 1979, Groundwater hydraulics: U.S. Geological Survey Professional Paper 708, 70 p.

Luza, K.V., 1986, Stability problems associated with abandoned underground mines in the Picher Field, northeastern Oklahoma: Oklahoma Geological Survey Circular 88, 114 p.

Macfarlane, P.A., 2007, The southeast Kansas Ozark aquifer water supply program phase 2 project results: Kansas Geological Survey Open-File Report 2007-20, 117 p.

Macfarlane, P.A., and Hathaway, L.R., 1987, The hydrogeology and chemical quality of groundwaters from the lower Paleozoic aquifers in the Tri-State region of Kansas, Missouri, and Oklahoma: Kansas Geological Survey Groundwater Series 9, $37 \mathrm{p}$.

Macfarlane, P.A., Healey, J.M., and Wilson, B.B., 2005, The southeast Kansas Ozark aquifer water supply program phase 1 project results: Kansas Geological Survey Open-File Report 2005-14, 52 p.

Macfarlane, P.A., Whittemore, D.O., and Hathaway, L.R., 1981, A report to the Kansas Department of Health and Environment on the hydrology and chemical quality o in the Lower Paleozoic aquifers in southeast Kansas and adjoining areas of Missouri and Oklahoma: Kansas Geological Survey Open-File Report 81-16, 48 p.

Marcher, M.V., and Bingham, R.H., 1971, Reconnaissance of the water resources of the Tulsa quadrangle, northeastern Oklahoma: Oklahoma Geological Survey Hydrologic Atlas 2, 4 sheets, scale 1:250,000.

Marcher, M.V., Kenny, J.F., and others, 1984, Hydrology of Area 40, western Region, Interior Coal Province, Kansas, Oklahoma, and Missouri: U.S. Geological Survey OpenFile Report 83-266, 97 p.

McCraken, M.H., 1971, Structural features of Missouri: Rolla, Missouri Division of Geology and Land Survey Report of Investigations 49, $99 \mathrm{p}$.

McKnight, E.T. and Fischer, R.P., 1970, Geology and ore deposits of the Picher field, Oklahoma and Kansas: U.S. Geological Survey Professional Paper 588, 162 p.

Motyka, J., Pulido-Bosch, A., Borczak, S., and Gisbert, J., 1998, Matrix hydrogeological properties of Devonian carbonate rocks of Olkusz (Southern Poland): Journal of Hydrology, v. 211, p. 140-150.

National Association of State Departments of Agriculture Research Foundation, 2009, State environmental laws affecting Kansas accessed April 2, 2009 at http://www. nasda.org/nasda/nasda/Foundation/STATE/Kansas\%20.pdf
National Climatic Data Center, 2008a, Climate normals: U.S. Department of Commerce, accessed September 11, 2008, at http://cdo.ncdc.noaa.gov/climatenormals/clim84/KS/ KS146414.txt

National Climatic Data Center, 2008b, Climate normals: U.S. Department of Commerce, accessed September 11, 2008, at http://cdo.ncdc.noaa.gov/climatenormals/clim84/OK/ OK345855.txt

National Climatic Data Center, 2008c, Climate normals: U.S. Department of Commerce, accessed September 11, 2008, at http://cdo.ncdc.noaa.gov/climatenormals/clim84/MO/ MO234315.txt

National Climatic Data Center, 2008d, Climate normals: U.S. Department of Commerce, accessed September 11, 2008, at http://cdo.ncdc.noaa.gov/climatenormals/clim84/AR/ AR032444.txt

Oklahoma Water Resources Board, 2009, Oklahoma groundwater law and water rights administration, accessed April 2, 2009 at URL http://www.owrb.ok.gov/news/news2/pdf news2/pres/GWLawPermitting.pdf

Parkhurst, D.L., 1987, Chemical analyses of water samples from the Picher mining area, northeast Oklahoma and southeast Kansas: U.S. Geological Survey Open-File Report $87-453,43 \mathrm{p}$.

Perry, C.A., Wolock, D.M., and Artman, J.C., 2004, Estimates of Flow Duration, Mean Flow, and Peak-Discharge Frequency Values for Kansas Stream Locations, U.S. Geological Survey Scientific Investigations Report 2004-5033, 651 p.

Playton, S.J., Davis, R.E., and McClaflin, R.G., 1980, Chemical quality of water in abandoned zinc mines in northeastern Oklahoma and southeastern Kansas: Oklahoma Geological Survey Circular 82, $49 \mathrm{p}$.

Pollock, D.W., 1994, User's guide for MODPATH/MODPATHPLOT, Version 3: A Particle tracking post-processing package for MODFLOW, the U.S. Geological Survey finite difference groundwater flow model: U.S. Geological Survey Open-File Report 94-464, p. 1-1-F-1.

Pugh, A.L., 2008, Summary of aquifer test data for Arkansas-1940-2006: U.S. Geological Survey Scientific Investiga $\neg$ tions Report 2008-5149, 33 p.

Pulido-Bosch, A. , Motyka, J., Pulido-Leboeuf, P., and Borczak, S., 2004, Matrix hydrodynamic properties of carbonate rocks from the Betic Cordillera (Spain): Hydrologic Process, v. 18, p. 2893-2906.

Reed, E.W., Schoff, S.L., and Branson, C.C., 1955, Groundwater resources of Ottawa County, Oklahoma: Oklahoma Geological Survey Bulletin 72, 203 p. 
Reed, T.B. and Czarnecki, J.B., 2006, Groundwater flow model of the Boone Formation at the Tar Creek Superfund Site, Oklahoma and Kansas: U.S. Geological Survey Scientific Investigations Report 2006-5097, 41 p.

Risser, D.W., Gburek, W.J., and Folmar, G.J., 2005, Comparison of methods for estimating ground-water recharge and base flow at a small watershed underlain by fractured bedrock in the eastern United States: U.S. Geological Survey Scientific Investigations Report 2005-5038, 31 p.

Rovey, C.W., and Cherkauer, D.S., 1995, Scale dependency of hydraulic conductivity measurements: Groundwater, v. 33, no. 5 , p. 769-780.

Spruill, T.B., 1987, Assessment of water resources in leadzinc mined areas in Cherokee County, Kansas, and adjacent areas: U.S. Geological Survey Water-Supply Paper 2268, 68 p.

Stramel, G.J., 1957, The hydraulic properties of the Ordovician rocks at Pittsburg, Kansas: Kansas Geological Survey Bulletin 127, part 5, p. 153-178.

U.S. Army Corps of Engineers, 2008, Monthly Charts for Grand Lake O' The Cherokees, Pensacola Dam, accessed 10/20/08 at http://www.swt-wc.usace.army.mil/PENScharts. html

U.S. Geological Survey, 2006, National elevation dataset: U.S. Geological Survey data available on the Web, accessed June 27, 2006, at http://ned.usgs.gov

U.S. Geological Survey, 2006, USGS water data for the Nation: U.S. Geological Survey data available on the Web, accessed March 27, 2006, at URL http://waterdata.usgs.gov/ nwis

Vineyard, J.D., and Feder, G.L., 1982, Springs of Missouri: Missouri Department of Natural Resources Publication Water Resources Report No. 29, 212 p.

Winston, R.B. 2008, Online guide to MODFLOW: U.S. Geological Survey, accessed on September 19, 2008 at http:// water.usgs.gov/nrp/gwsoftware/modflow2000/MFDOC/ index.html

Wittman, J.W., Kelson, V., and Wilson, T., 2003, Final report: Publishing support provided by: Lafayette and Rolla Publishing Service Centers Source of supply investigation for Joplin, Missouri: Wittman Hydro Planning Associates, Inc., 97 p.

For more information concerning the research
described in the report:
U.S. Geological Survey
Arkansas Water Science Center
401 Hardin Road
Little Rock, AR 72211-3528
(501) 228-3600

http://ar.water.usgs.gov 
